\title{
WATER QUALITY MODELING STUDY OF PROPOSED REREGULATION DAM DOWNSTREAM FROM BUFORD DAM CHATTAHOOCHEE RIVER, GEORGIA
}

by

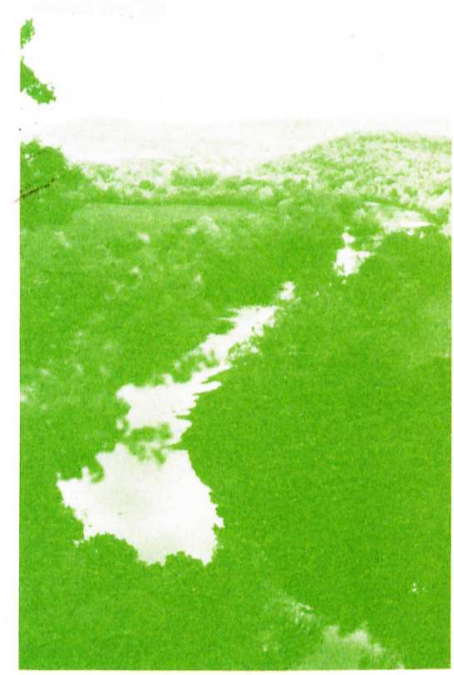

Marc J. Zimmerman, Mark S. Dortch

Environmental Laboratory

DEPARTMENT OF THE ARMY

Waterways Experiment Station, Corps of Engineers PO Box 631, Vicksburg, Mississippi 39181-0631
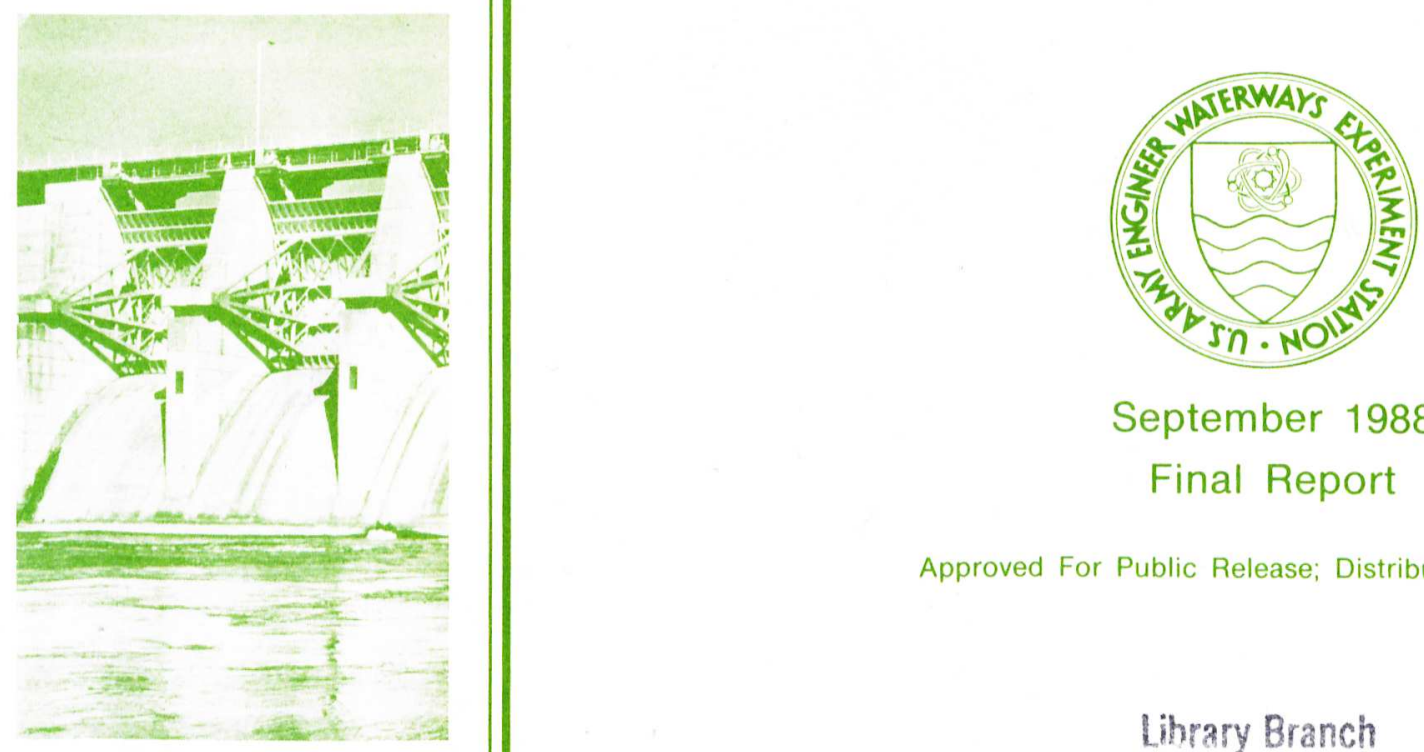

September 1988

Final Report

Approved For Public Release; Distribution Unlimited

Lihrary Branch

Technical information Center

U.S. Army Engineer Wateruays Experiment Station Vicksburg, Wississippl

Prepared for US Army Engineer District, Savannah Savannah, Georgia 31402-0889 
Destroy this report when no longer needed. Do not return it to the originator.

The findings in this report are not to be construed as an official Department of the Army position unless so designated by other authorized documents.

The contents of this report are not to be used for advertising, publication, or promotional purposes. Citation of trade names does not constitute an official endorsement or approval of the use of such commercial products. 


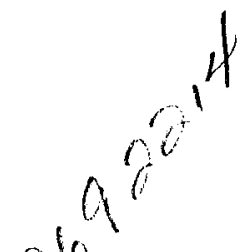

Unclassified

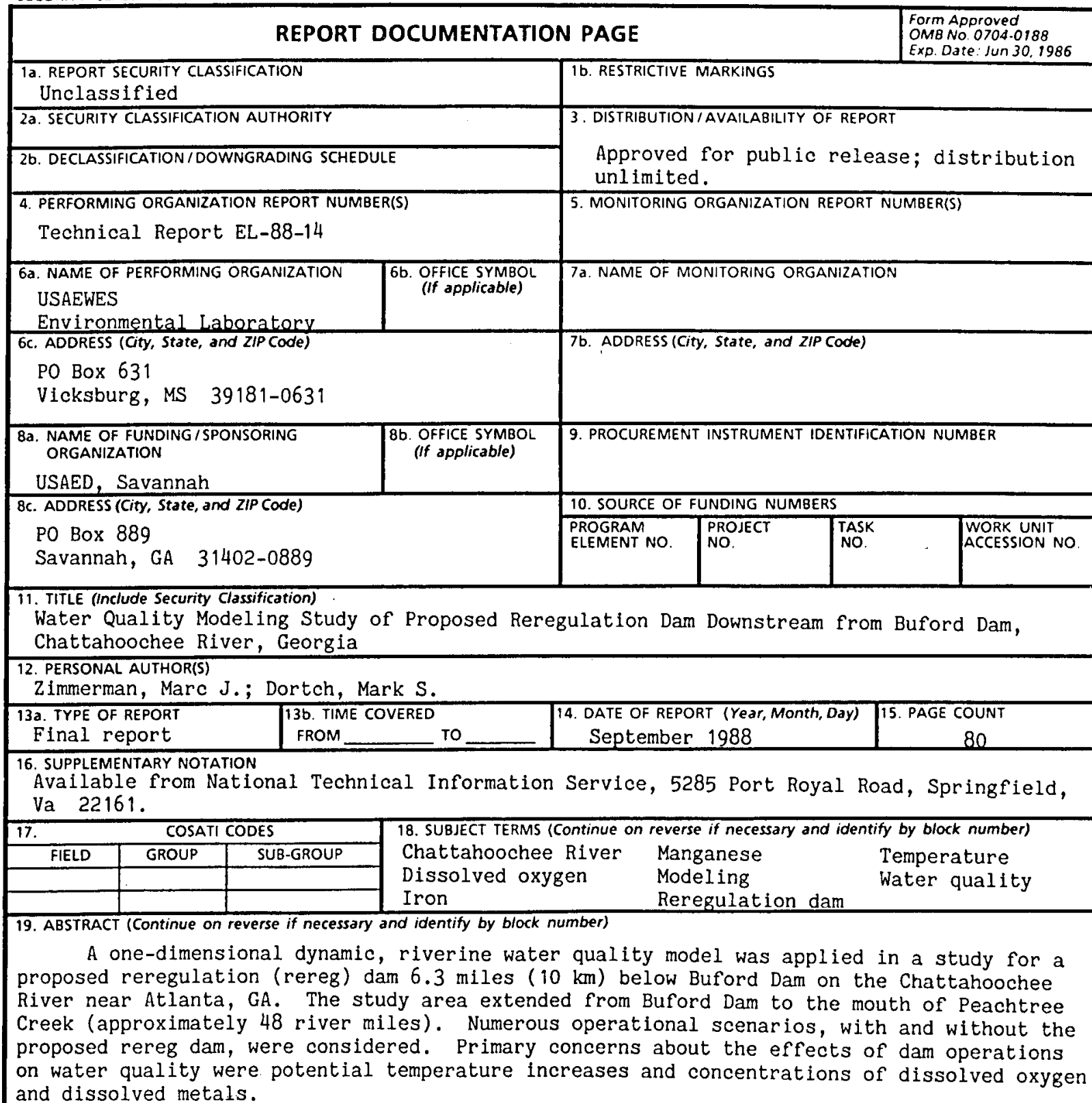

Results generally showed that operating a rereg dam in this system would result in temperature increases in the river mainly due to the volume of warmer releases from Buford Dam; in addition, rereg dam operations would lower the concentrations of dissolved metals. In the rereg pool, dissolved oxygen concentrations may be low in the fall, but should exceed $5.0 \mathrm{mg} / \mathrm{l}$ at all times downstream.

\begin{tabular}{|c|c|c|}
\hline $\begin{array}{l}\text { 20. DISTRIBUTION/AVAILABILITY OF ABSTRACT } \\
\text { Q UNCLASSIFIED/UNLIMITED } \square \text { SAME AS RPT. }\end{array}$ & $\square$ DTIC USERS & $\begin{array}{l}\text { 21. ABSTRACT SECURITY CLASSIFICATION } \\
\text { Unclassified }\end{array}$ \\
\hline 22a. NAME OF RESPONSIBLE INDIVIDUAL & & \begin{tabular}{|l|l|l} 
22b. TELEPHONE (Include Area Code) & 22c. OFFICE SYMBOL
\end{tabular} \\
\hline
\end{tabular}


<smiles>C1#CCCC1</smiles> 
This report was sponsored by the US Army Engineer District, Savannah (SAS), and was monitored by Mr. John Meyer of SAS. The report describes the results of the calibration and application of the one-dimensional, riverine water quality model, CE-QUAL-RIV1, to a 50-mile reach of the Chattahoochee River where the construction of a reregulation dam has been proposed.

Dr. Marc J. Zimmerman and Mr. Mark S. Dortch, Water Quality Modeling Group (WQMG), Ecosystem Research and Simulation Division (ERSD), Environmental Laboratory (EL), US Army Engineer Waterways Experiment Station (WES), performed the study and prepared the report. Mr. James Gallagher, SAS, provided flow routings required to conduct model simulations. Ms. Sandra Bird, WQMG, wrote the computer subroutine for wind-driven reaeration. Dr. Robert E. Faye, US Geological Survey, and Dr. Roy Burke III, Georgia Environmental Protection Division, provided valuable data and assistance. Dr. James L. Martin, formerly of the WQMG, and Mr. Ross W. Hall, WQMG, reviewed the report. The study was conducted under the general supervision of Mr. Donald Robey, Chief, ERSD, and Dr. John Harrison, Chief, EL. The report was edited by Mrs. Nancy Johnson of the WES Information Products Division, under the Intergovernmental Personnel Act.

COL Dwayne G. Lee, EN, is Commander and Director of WES. Dr. Robert W. Whalin is Technical Director.

This report should be cited as follows:

Zimmerman, Marc J., and Dortch, Mark S. 1988. "Water Quality Modeling Study of Proposed Reregulation Dam Downstream from Buford Dam, Chattahoochee River, Georgia," Technical Report EL-88-14, US Army Engineer Waterways Experiment Station, Vicksburg, MS. 


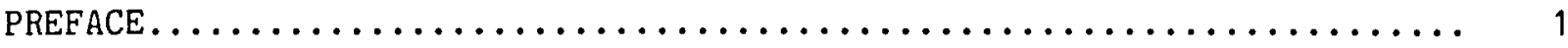

CONVERSION FACTORS, NON-SI TO SI (METRIC) UNITS OF MEASUREMENT........ 3

PART I $\quad$ INTRODUCTION.............................. 4

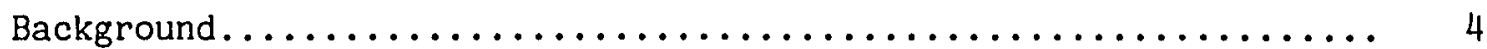

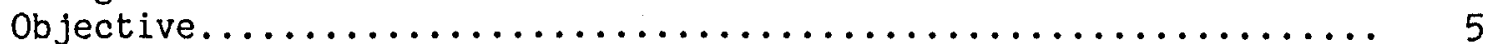

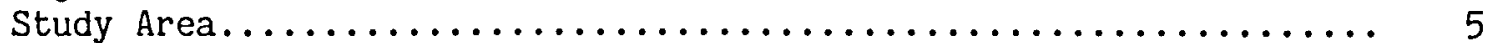

PART II: MODEL DESCRIPTION......................... 7

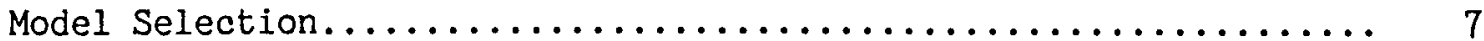

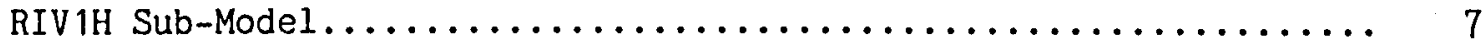

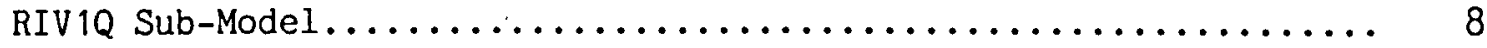

PART III: MODEL CALIBRATION AND CONFIRMATION................ 11

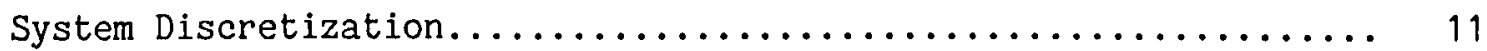

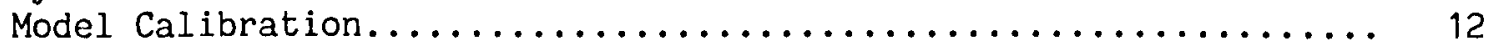

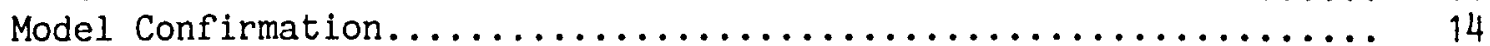

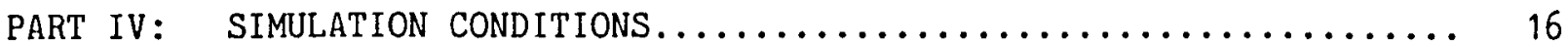

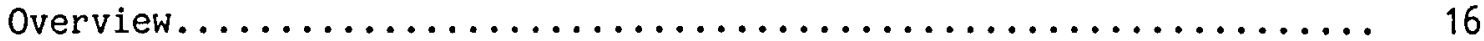

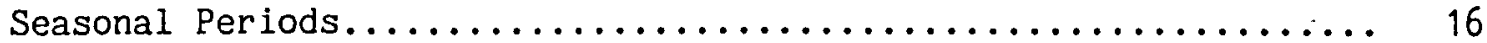

Meteorological Conditions......................... 17

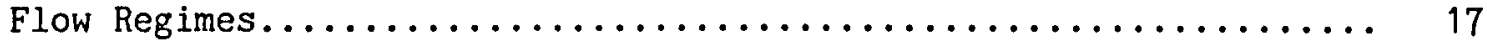

Initial Water Quality Conditions...................... 19

Water Quality Boundary Conditions...................... 19

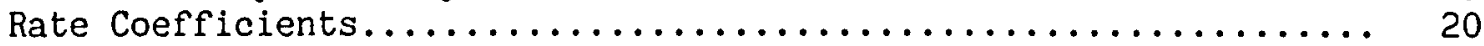

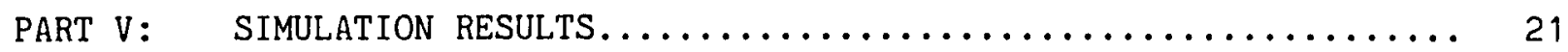

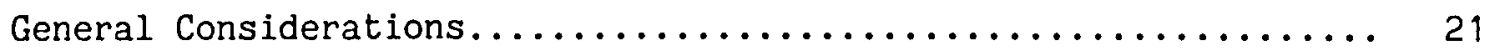

Basic 1-Day Rereg Versus MFSF........................ 21

Hydropower Versus Nonhydropower Rereg Dam Options............. 22

Basic 2.5-Day Rereg Versus Alternate 2.5-Day Rereg............ 23

MIP Versus Three Reregulation Options................... 23

Plan B Versus Three Reregulation Options.................. 26

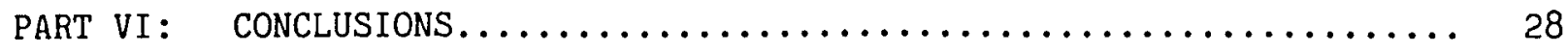

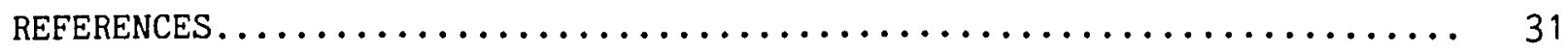

Tables 1-8

Figures 1-34 


\section{CONVERSION FACTORS, NON-SI TO SI (METRIC) \\ UNITS OF MEASUREMENT}

\begin{tabular}{|c|c|c|}
\hline Multiply & By & To Obtain \\
\hline acre-feet & $1,233.489$ & cubic metres \\
\hline cubic feet & 0.02831685 & cubic metres \\
\hline Fahrenheit degrees & $5 / 9$ & $\begin{array}{l}\text { Celsius degrees } \\
\text { or kelvins* }\end{array}$ \\
\hline feet & 0.3048 & metres \\
\hline miles (US statute) & 1.609347 & kilometres \\
\hline square feet & 0.09290304 & square metres \\
\hline
\end{tabular}

* To obtain Celsius (C) temperature readings from Fahrenheit (F) readings, use the following formula: $C=(5 / 9)(F-32)$. To obtain Kelvin (K) readings, use: $\mathrm{K}=(5 / 9)(\mathrm{F}-32)+273.15$. 


\section{WATER QUALITY MODELING STUDY OF PROPOSED REREGULATION DAM DOWNSTREAM}

FROM BUFORD DAM, CHATTAHOOCHEE RIVER, GEORGIA

PART I : INTRODUCTION

Background

1. The Metropolitan Atlanta Area Water Resources Management Study (MAAWRMS) (1981), sponsored by the US Army Engineer District, Savannah (SAS), addressed alternative methods of providing water to the Atlanta area to meet the region's water supply needs well into the twenty-first century. Alternatives considered included construction of a reregulation (rereg) dam 6.3 miles* below Buford Dam, reallocation of storage at Lake Sidney Lanier, and dredging of Morgan Falls Reservoir in conjunction with storage reallocation at Lake Sidney Lanier. The MAAWRMS Study Group recommended the rereg dam as the best alternative.

2. The MAAWRMS Executive Group also recommended studies to predict water quality changes (resulting from reregulation) in the Chattahoochee River between Buford Dam and Peachtree Creek. In particular, they voiced concerns about minimizing damage to the existing trout fishery. These concerns were defined with the following water quality criteria:

a. Water temperatures in excess of $23.3^{\circ} \mathrm{C}\left(74^{\circ} \mathrm{F}\right)$ at Peachtree Creek should never be allowed to occur.

b. Water temperatures in excess of $18.8^{\circ} \mathrm{C}\left(66^{\circ} \mathrm{F}\right)$ at Peachtree Creek should not be allowed to occur at a greater frequency or longer duration than is the case now.

c. Water temperatures at the hatchery intake should not be allowed to exceed $18.3^{\circ} \mathrm{C}\left(65^{\circ} \mathrm{F}\right)$.

d. Three-day running averages of simulated water temperatures associated with reregulation should not exceed those associated with unreregulated water temperatures by $1.1^{\circ} \mathrm{C}\left(2^{\circ} \mathrm{F}\right)$.

e. Dissolved oxygen (DO) concentrations should be maintained above $5 \mathrm{mg} / \mathrm{l}$.

f. Concentrations of dissolved iron or manganese should not exceed $1 \mathrm{mg} / \mathrm{l}$.

These studies would also identify potential water quality problems related to

* A table of factors for converting non-SI units of measurement to SI (metric) units is presented on page 3. 
the rereg dam which would adversely affect either the state trout hatchery or the river trout fishery.

\section{Objective}

3. The purpose of this study was to provide predictions, through numerical model simulations, of the proposed rereg dam's impact on selected water quality parameters in the Chattahoochee River (Figure 1) between Buford Dam (river mile 348.3) and Peachtree Creek (river mile 300.98).

\section{Study Area}

4. The study reach of the river currently has two dams, Buford Dam and Morgan Falls Dam (Figure 1). Buford Dam impounds Lake Sidney Lanier, a large, deep, multipurpose reservoir constructed and operated by SAS. One of its purposes is peaking hydropower generation. The maximum discharge rate from Buford Dam during peak power generation is about $8,400 \mathrm{cfs}$. A minimum flow of approximately $550 \mathrm{cfs}$ is maintained during off peak power periods to provide present water supply and to maintain downstream water quality.

5. Morgan Falls Dam (river mile 312.62), a hydropower dam owned and operated by the Georgia Power Company, impounds Bull Sluice Lake. Bull Sluice Lake is a small, shallow, run-of-the-river impoundment that does not stratify vertically. At normal power pool (el 853.6* msl), Morgan Falls Dam impounds approximately 2,500 acre-ft with a maximum depth of $16.6 \mathrm{ft}$. Although Morgan Falls Dam is operated for power production, its discharges largely reflect the releases from Buford Dam because it has so little storage capacity.

6. As originally proposed, the rereg dam, which would be sited at river mile 342.0, is designed to eliminate the need for minimum flow releases from Buford Dam by storing the peaking discharges while providing a relativel.y steady release to the Chattahoochee River. The minimum release from the rereg dam would be approximately 1,500 cfs. At present, two design options are under consideration; the first would impound a 1-day rereg water supply, while the second would store enough water to sustain steady releases for 2.5 days.

* All elevations (el) cited herein are in feet referred to mean sea level (msl). 
The 1-day water supply pool would fluctuate between el 912 and el 922 , and have a maximum depth of approximately $30 \mathrm{ft}$, with storage of 7,200 acre-ft. The 2.5-day pool would vary between el 912 and el 924, with a maximum depth of $32 \mathrm{ft}$ and storage of 8,900 acre-ft. The primary reason for considering a 2.5-day water supply rereg dam is for its proposed use in hydropower generation; according to SAS, the benefit-cost ratio is significantly greater with the rereg option.

7. The approach taken in this study was to consider existing and future water supply needs as estimated in MAAWRMS (1981) and to apply a water quality model to the reach from Buford Dam to Peachtree Creek. For each water supply estimate, scenarios were developed which simulated required operations, routings, and resulting water quality. Water quality differences among rereg options and between unregulated and reregulated conditions were examined extensively and in detail. The following sections of this study describe the model, its calibration and confirmation, simulation conditions and results, and conclusions. 


\section{Model Selection}

8. A one-dimensional (1-D), riverine water quality model developed by Bedford, Sykes, and Libicki (1982) was selected for the study. The highly unsteady nature of flows in this system required application of an unsteady flow model. A cross-sectionally averaged, longitudinally 1-D model was considered appropriate for this river system which exhibits longitudinal changes in water quality but is fairly well-mixed laterally and vertically. Longitudinal gradients are also expected to be more important than vertical and lateral gradients in the rereg pool because of the pool's shallowness, long length, and short retention time. Likewise, Bull Sluice Lake experiences very little vertical stratification and, thus, fits the 1-D assumption.

9. The Bedford model was chosen over other unsteady flow water quality models for its capability to include in-stream hydraulic control structures (i.e., the rereg dam and Morgan Falls Dam). Two submodels constitute the Bedford code. The hydrodynamic code (RIV1H) simulates water movement within the modeled system; this code can stand alone and simulates river flows, watersurface elevations (stage), depths, cross-sectional areas, and top widths. The water quality submodel (RIV1Q) requires output from RIV1H to drive the transport algorithms for water quality simulations.

\section{$\underline{\text { RIV1H Submodel }}$}

10. RIV1H, patterned after the National Weather Service Dambreak Model (Fread 1978) uses the four-point, implicit, finite-difference method to solve for flows and elevations. The advective term of the momentum equation is left in nonlinear form; thus, a Newton-Raphson iteration is used to converge the solution at each time step. The model permits relatively unequal space and time steps. The model also allows simulation of branched river systems with multiple hydraulic control structures.

11. RIV1H requires river geometry descriptions and flow conditions to perform the hydrodynamic calculations. The stretch or reach of the river under study is broken into segments. Each segment is divided by a series of nodes where river geometry (cross-sectional area and bed elevation) and initial conditions are defined and where the model predicts hydrodynamic and 
water quality conditions. River geometry data include locations of control structures, distances between nodes, stream bed elevations, cross-sectional area versus depth equation coefficients, and Manning's coefficients. Flow conditions include initial flow rates and depths, lateral inflows or withdrawals, and boundary conditions. Boundary conditions may be provided in terms of flows, stages, or rating curves at control structures or boundaries.

12. Cross-sectional area and discharge are the dependent variables of the hydrodynamic equations. Following computation of these variables, stage, depth, and width are determined. Time histories of all these variables can be printed out for each node of the river model. Additionally, RIVIQ uses all of these variables to calculate dynamic changes in concentrations of water quality variables and temperature.

\section{$\underline{\text { RIV1Q Submodel }}$}

13. After RIV $1 \mathrm{H}$ computes hydraulic conditions, RIV1H output drives the water quality transport predictions in RIV1Q. RIV1Q uses an explicit, finitedifference method to solve the constituent transport/reaction equations. A two point, fourth-order accurate scheme developed by Holly and Preissmann (1978) provides highly accurate advective transport during the solution of these equations.

14. RIVIQ was originally intended to simulate effects of wastewater or pollutant loadings to riverine systems. The program could calculate up to seven given water quality variables: temperature, dissolved oxygen (DO), carbonaceous biochemical oxygen demand (CBOD), organic nitrogen, ammonia nitrogen, nitrate nitrogen, and phosphate phosphorus, as well as a userselected variable, e.g., coliform bacteria or a chemical pollutant. Additionally, the effects of phytoplankton and macrophyte growth and decay on nutrient balances and DO were included.

15. For this study, the program was modified to include dissolved iron, dissolved manganese, and coliform bacteria as modeled variables. Phytoplankton and macrophytes were assumed light-limited only. A further modification was the removal of turbulence as a factor directly influencing decay rates; a first attempt to effect this removal left the model predicting oxygen depletion at an unrealistically high rate; this oversight was subsequently corrected. 
16. A brief description of modeling considerations for the ten water quality variables follows. While these variables and their effects are included in this study, only temperature, DO, dissolved manganese, and dissolved iron are reported.

17. Temperature computations were modified by replacing the equilibrium temperature method with a direct energy balance technique (Roesner, Giguere, and Evanson 1977). The calculations incorporate effects of net short wave and long wave radiation, back radiation, evaporative cooling, conduction, and thermal loadings from inflow boundaries and lateral inputs. Meteorological data requirements for calculating temperatures include dew point and dry bulb temperatures, atmospheric pressure, wind speed, and cloud cover. Computed temperatures affect reaction rates for other water quality constituents.

18. Computing the DO concentration is a primary focus of the model. Reaeration and photosynthesis are sources of oxygen, while organic matter decay, nitrification, plant respiration, and oxidation of iron and manganese deplete DO. Stream reaeration follows the Tsivoglou formulation (Tsivoglou and Wallace 1972); structural reaeration through the rereg dam follows an empirical relationship developed by Wilhelms and Smith (1981); and, in pools above the rereg dam and Morgan Falls Dam, wind-driven reaeration ( $0^{\prime}$ Connor 1983) has been incorporated into the model. Releases from Buford Dam, Morgan Falls Dam, and the 2.5-day water supply rereg option are assumed not to involve structural reaeration, as these are hydropower releases with little energy left in the flow.

19. CBOD represents the amount of biodegradable organic matter present in terms of oxygen equivalents required for its complete decay. Biodegradable organic material may enter the system through lateral and boundary inflows. Oxygen or nitrate can act as terminal electron acceptors for CBOD decay, depending on half saturation constants used and concentrations of oxygen and nitrate present; that is, oxygen or nitrate may be reduced in order to oxidize the organic matter. The amount of oxygen reduced decreases, and the amount of nitrate reduced increases, as DO approaches zero. CBOD removal, a first-order process, does not occur in the absence of oxygen or nitrate.

20. Nitrogen occurs in three forms in the model--organic nitrogen, ammonia nitrogen, and nitrate nitrogen, all of which may enter the system via boundary inputs and lateral inflows. Organic nitrogen is a constituent of organic matter, and the model converts organic nitrogen to ammonia through 
hydrolysis. Ammonia is derived from organic nitrogen and algal and macrophyte decay, all first-order processes. Ammonia is lost from the system by nitrification and uptake by plants, also first-order processes. Nitrate is formed from ammonia by nitrification and removed by plant uptake and by denitrification under low DO conditions.

21. Phosphate phosphorus is removed from the system by algal and macrophyte uptake and released to the system by plant decay. Phosphate may enter the system via upstream boundary inflows or lateral inflows.

22. Dissolved iron and manganese may enter the system only through dam releases or lateral inflows. When DO is greater than $1.0 \mathrm{mg} / \ell$, dissolved iron and manganese are oxidized (first-order processes) and lost from the system.

23. In this application, fecal coliform bacteria enter the system only through lateral inflows which represent agricultural or urban runoff or wastewater return flows. Fecal coliform do not reproduce in the aerobic free state, and their populations decay exponentially. 


\section{System Discretization}

24. RIV1H, as used in this study, models the Chattahoochee River as a series of two (without rereg dam) or three (with rereg dam) segments which are bounded by control structures at their upstream ends. The final lower boundary condition at Peachtree Creek is defined by a rating curve. The crosssectional area at each node is described by the equation $\mathrm{A}=\mathrm{C} 1 * \mathrm{H}+\mathrm{C} 2$ * $\mathrm{H} *$ * $\mathrm{C} 3$, where $A$ is the cross-sectional area; $H$ is the depth from the stream bed to the water surface; and the $C$ values are user-defined coefficients. The $\mathrm{C}$ values are fitted so the model's description closely approximates the stream's cross-sectional area versus depth profile. At any given node, lateral inflows (streams and creeks) and withdrawals can be defined; the net input or withdrawal is divided by the length of the reach between nodes and is given as cubic feet per second-foot.

25. Two slightly, but significantly, different sets of geometric attributes are presented in Tables 1 and 2. Table 1 describes how the river is modeled without the rereg dam, and Table 2 contains the data used to simulate the river with either the proposed 1- or 2.5-day water supply rereg dams in place. (Descriptions of the flow regimes are provided later in Table 3.) Without the rereg dam, the stretch of river is composed of two segments; the first extends from Buford Dam to Morgan Falls Dam and contains 35 nodes. The second segment runs from Morgan Falls to Peachtree Creek and has 15 nodes. The rereg dam at river mile 342.0 (Table 2) divides the upper segment in two parts, an upper part of 11 nodes and a lower part of 25 nodes. Thus, simulations without reregulation have 50 nodes, while those with the rereg dam have 51 nodes (one extra node being needed at the rereg dam). Much of the physical data for the simulations are derived from previous studies, such as Jobson and Keefer (1979), Faye and Cherry (1980), and Benedict (1980a), and surveys performed by the US Army Engineer District, Mobile, and the US Geological Survey (USGS).

26. The unreregulated and proposed reregulated systems obviously vary physically around the rereg site. Differences in some geometric parameters and Manning's coefficients, in particular, are necessary to simulate conditions of the rereg pool. For example, the cross-sectional area coefficients 
of the rereg pool must satisfy cross-sectional area requirements, and the volume of the model rereg pool must closely approximate that of the prototype. Additionally, Manning's coefficients decrease as the rereg pool depth increases in the downstream direction.

27. A time step of 5 min was selected for all model simulations. With the explicit scheme of RIV $1 Q$ and the highly dynamic flow with relatively large flow rates during power generation, this small time step was required to maintain RIV1Q's numerical stability.

\section{Model Calibration}

\section{Hydraulic calibration}

28. Flow and stage calibration studies used USGS data from earlier flow investigations between Buford Dam and the Georgia Highway 141 bridge (river mile 330.76). Initial calibrations were conducted for a steady-state, low flow release of 550 cfs from Buford Dam. Values for stage height along the river during documented steady, low flow conditions on 17 July 1976 (Jobson and Keefer 1979) were compared with model predictions. Manning's n values were adjusted where necessary to bring model stages in agreement with those observed. Observations for most of the downstream reach were unavailable. Stage readings were available at two downstream nodes, the Atlanta Water Works (river mile 300.98) and the Atlanta Gage (river mile 302.98). Manning's $n$ values for the downstream reach were adjusted to approximate values used upstream (i.e., high values for shoals and low values for pools).

29. The results of these calibrations are shown in Figure 2 as elevation versus river mile. Bed elevations and locations of each node are also shown in the figure.

30. After completing the steady, low flow calibration, unsteady flow simulations were initiated to test the adequacy of $\mathrm{n}$ values and model geometry. Data available from studies conducted during 21-23 March 1976 (Faye and Cherry 1980) provided the basis for unsteady flow comparisons. Lateral inflows were significant during this period, so estimates of these quantities were required. By applying a weighted average based on drainage basin area, Big Creek gaged flows were used to estimate all other ungaged inflows. Unsteady flow comparisons revealed that several nodes (primarily in shoal areas) required Manning's $n$ values that varied from a high value at low stage to a 
low value at high stage. Thus, a linear fit of the calibrated low and high flow $n$ values was developed and used for several nodes as noted in Tables 1 and 2 along with the $n$ values. The $n$ values closely approximate values obtained by Jobson and Keefer (1979) during their flow simulations of the same events (17-19 July 1976 and 21-23 March 1976). The steady and unsteady flow calibrations allowed the development of a rating curve for the boundary condition at the last node (Peachtree Creek). Figure 3 shows the results of the unsteady flow calibration at five stations for the period 21-23 March 1976. Mass transport

31. In addition to calibrating the model to simulate hydraulic conditions accurately, transport of a conservative substance (dye) was modeled and results were compared with observed steady and unsteady dye tracer studies. These simulations tested the mass transport capability of RIV1Q before attempting simulations of water quality.

32. A dye slug was introduced into the steady, low flow simulation, and the locations and timing of the dye peak were determined from model output. These results were compared with travel times reported by the USGS (1972) for steady, low-flow tracer studies. This comparison (Figure 4) indicated that the model reliably simulated the travel time of the system.

33. Unsteady flow field studies of 21-23 March 1976 included dye tracer and temperature measurements (Jobson and Keefer 1979) in addition to stage recordings. Dye was continuously released at a constant rate just below Buford Dam. Dye concentrations were recorded at two downstream stations throughout the unsteady flow event. The dye tracer was modeled by introducing a constant source of a conservative constituent at the first node. The computed and observed dye concentration histories at both downstream stations are shown in Figure 5. The longitudinal dispersion coefficient used for these and all subsequent simulations was $250 \mathrm{sq} \mathrm{ft} / \mathrm{sec}$. This value was estimated from the relationship $D=250.0 * R *$ US , where $D$ is the dispersion coefficient, $R$ the hydraulic radius, and $U S$ the shear velocity (Fischer 1973). Approximating the product $R$ * US to equal 1.0 yielded a value of 250.0 for $D$. This value gave good results, while smaller and larger values for $D$ did not improve the results shown in Eigure 5. Very little numerical dispersion occurred because of the high order of accuracy of the Holly-Preissmann (1978) scheme. The favorable comparisons in Figures 4 and 5 confirmed the ability of the model to simulate mass transport. 
Thermal conditions

34. Meteorological data for simulating temperature were obtained from the National Oceanic and Atmospheric Administration (NOAA) and represent actual conditions experienced at the Atlanta airport weather station during the time period studied. The parameters used in the model included dew point and dry bulb temperatures, atmospheric pressure, wind speed, and cloud cover. These data were available at hourly intervals; thus, hourly updates of meteorological data were used for all simulations.

35. After evaluating model mass transport, RIV1Q's ability to model temperature was tested. Temperature data taken at three locations by the USGS (1972) along with Morgan Falls operations records obtained from the Georgia Power Company for the period 21-23 March 1976, provided the basis for the simulations, supplementing information in Jobson and Keefer (1979) and Faye and Cherry (1980). Lateral inflow temperatures were approximated with the mean of the March monthly averaged equilibrium temperatures (Edinger and Geyer 1965) as calculated by Benedict (1980b). Results of this simulation (Figure 6) compared favorably with observed conditions.

\section{Model Confirmation}

36. The validity of model predictions resulting from the calibration was tested by simulating flow and temperature for 12-19 July 1976 and by comparing these simulations with stage and temperature recordings at the Atlanta Gage. The Atlanta Gage and Buford Dam discharge, stage, and temperature recordings were provided by the USGS office (1972), Doraville, GA. Data were not available at any other locations between Buford Dam and the Atlanta Gage for this period (except for the steady, low-flow stage readings on $17 \mathrm{July}$ 1976 as discussed previously). The Georgia Power Company provided Morgan Falls Dam discharge data. Appropriate meteorological data were obtained from NOAA weather data (Atlanta airport). The mean value for the monthly (July) averaged equilibrium temperature, in this case modified for shading (Benedict 1980b), was used for the lateral inflow temperature. Simulated and observed stages and temperatures at the Atlanta Gage (river mile 302.96), compared in Figures 7 and 8 , proved quite satisfactory (predicted values within about $1.0^{\circ} \mathrm{C}$ of observed most of the time; predicted minus observed mean error $=-0.15^{\circ} \mathrm{C}$, root mean square error $=1.22^{\circ} \mathrm{C}$ ); the majority of discrepancies 
resulted from estimating initial conditions.

37. Existing data are insufficient to confirm the model's ability to simulate other water quality variables as they change with time. However, monthly water quality sampling data yielded a range of autumn values at four sampling sites (water supply intakes) for DO, CBOD, ammonia nitrogen, and nitrate nitrogen (Figure 9). These observations provided an approximate means of checking the model's adequacy. Fall conditions were selected because of the occurrence of $10 \mathrm{~W}$ DO and reduced chemical species in the tailwater. Simulated values for these four water quality variables generally fell within the range of field observations; the simulated average Do value at river mile 325.44 exceeded the observed range. Several ungaged, unsimulated, minor tributaries located upstream may have contributed to this deviation. Alternatively, the extreme meteorological conditions used in the simulation may not have reflected conditions during the period for which field data were available. It is also possible that the stream reaeration equation overpredicted the rate of reaeration in the reach between the first and third observation stations. Some model coefficients were varied in an attempt to bring model DO closer to observtion, but the model was relatively insensitive to these variations below the upper 12 miles. 


\section{PART IV: SIMULATION CONDITIONS}

\section{Overview}

38. Simulation conditions in this study represented the critical seasonal periods of summer and fall (referred to as July and October). Within this framework, numerous scenarios exemplifying a variety of flow regimes with and without a rereg dam in place were tested. We also considered rereg options with and without hydropower. Table 3 contains a brief description of the alternatives examined and a descriptor for referencing the alternative throughout this study. Various facets of the simulation conditions, such as seasonal conditions, meteorology, flow regimes, and water quality conditions, are discussed below.

\section{Seasonal Periods}

39. Water quality conditions in the Chattahoochee River are the most stressful during midsummer and fall. The month of July (midsummer) generally exhibits the warmest atmospheric temperatures along with high solar radiation and can be expected to cause the highest water temperatures. A review of temperature records at the Atlanta Water Works supports this assumption. In October and November, water quality of releases from Buford Dam is poorest in terms of high temperatures, low concentrations of DO, and high concentrations of undesirable, oxygen-demanding, dissolved materials (ammonia, manganese, and iron). July water temperatures and October DO concentrations are particularly critical for the river's trout fishery. Therefore, midsummer and fall are used for the seasonal simulation conditions.

40. An 8-day time period was chosen as a basis for both summer and fall simulations for the following reasons. First, a full week and a day were more than enough time for the rereg dam to influence the entire reach; potentially unrealistic initial conditions in the system were eliminated by reinitializing each simulation with simulation output taken after $168 \mathrm{hr}$ (Monday, 1 week after starting). Second, an 8-day period included the week days and the weekend, with their particular routings. Third, application of the unsteady flow models, RIV1H and RIV1Q, became increasingly expensive for longer simulation periods, and the benefits of Ionger simulation periods (such as weeks or 
months) did not warrant the additional costs. Longer simulation periods are practical for simpler routing methods and steady-state riverine models, but, for this study, results would not be as accurate as with a dynamic routing model.

\section{Meteorological Conditions}

41. To select reasonable, yet relatively stressful meteorological conditions, historical meteorological data were analyzed to determine conditions that are exceeded about once every 10 years. It was first assumed that daily average air temperatures were good indicators of warm, cool, etc., meteorological conditions. Daily average air temperatures were computed for each day in the months of July, October, and November from NOAA data records (Atlanta airport) covering the time period from 1945-1982. Next, 3-day running averages of these daily average air temperatures were computed and, for each year of record, the maximum 3-day running average of air temperature, 3T, was determined for the months considered (July or October-November). Three-day averages were used because the average hydraulic retention time of the system for present conditions is about three days. At this point, it was possible to construct an exceedance frequency table for the 3T data and determine the 3T10 for July or October-November. The $3 \mathrm{~T} 10$ is defined as the $3 \mathrm{~T}$ that for a given month is expected to occur or be exceeded every 10 years. For this study, the $3 \mathrm{~T} 10$ was determined only for July and October-November, the two time periods of interest. With the 3T10 information, meteorological data were directly examined and the 8-day time period which contained the particular 3T10 was selected. For July, this was 24-31 July 1949; and, for October-November, it actually ran from 30 September-7 October 1955. The meteorological data for these time periods were used for the summer (referred to as July) and fall (referred to as October) simulation conditions, respectively.

\section{Flow Regimes}

42. According to projections, present flow conditions will not satisfy future water supply needs. Therefore, since some operation modifications will be made, it might seem unnecessary to compare future water quality conditions, as affected by the insertion of a rereg dam at river mile 342.0 on the Chattahoochee River, with existing conditions without the dam. However, in order to compare effects of modifications, this study compares water 
quality in the unreregulated system with rereg dam alternatives for present and future water needs. The future alternative without reregulation (Plan B), as presented here, would require reallocation of storage in Lake Sidney Lanier.

43. Operation regimes for the modeled systems with and without the rereg dam were provided by SAS. These routings were calculated with the HEC-5 Simulation of Flood Control and Conservation Systems program using estimated needs for withdrawals by municipal water supply intakes. The Georgia Department of Natural Resources (DNR) provided lateral inflow rates from creeks.

44. Figure 9 presents discharge scenarios without the rereg dam in place (Modified Interim Plan (MIP) and Plan B), and Figure 10 shows five different rereg flow regimes. Table 3 describes all operations in more detail. These figures include hydrographs at Buford Dam, Morgan Falls Dam, and the proposed rereg dam. All simulations start on Monday morning and run through $2400 \mathrm{hr}$ on the following Monday.

45. Under MIP, which represents existing conditions, Buford Dam discharges for $2 \mathrm{hr}$ per day at 8,400 cfs, and Morgan Falls Dam releases a steady flow of about 1,054 cfs. Plan B (future conditions without reregulation) would have Buford Dam releasing 5,000 cfs for $5 \mathrm{hr}$ per day and Morgan Falls Dam releasing daily peaking flows. Both the MIP and Plan B options maintain minimum releases of 600 cfs from Buford Dam during off-peak periods.

46. This study examines five-flow regimes (Figure 10) incorporating rereg dam operations. Other than obvious differences caused by inclusion of the rereg discharges, several changes in operations should be noted. Inclusion of a rereg dam on the Chattahoochee River could eliminate the need for minimum releases from Buford Dam; however, the alternate 1- and 2.5-day rereg options, intended to maintain low temperature outflows from Buford Dam, use 600-cfs minimum flows, and the basic 2.5-day water supply option requires several hours of 600 cfs flow early Monday morning to maintain a wet channel below Buford Dam. The three 1-day water supply rereg options (basic 1 day, alternate 1 day, and Morgan Falls Steady Flow (MFSF)) require weekend hydropower generation at Buford Dam, while the 2.5-day options do not. With the exceptions of minor adjustments to water-surface elevations on Fridays under the basic 1- and 2.5-day water supply options, release flows from the rereg dam remain constant. The MFSE option does not have peaking flows at Morgan Falls Dam as do the four other options. 
47. Starting water quality conditions were determined by running the model through a trial simulation and, then, reinitializing, using predicted water quality values after 168 simulation hours (Monday morning) as initial conditions. Earlier testing indicated that unrealistic, transient stream water quality values would result during the first two simulation days unless good starting values were selected. It was impossible to start with observed field values or estimates because such detailed data were unavailable for the periods of interest.

\section{Water Quality Boundary Conditions}

48. Concentrations of water quality variables change with release rate from Buford Dam because the vertical thickness of the withdrawal zone in the Lanier pool depends on discharge rate. With penstock intakes deep in the Lanier pool, discharge through them creates a withdrawal zone predominately in the lower portion of the pool. The smaller the discharge, the more concentrated is the withdrawal zone near the bottom of the reservoir. For larger discharges, the centroid of the withdrawal zone is higher in the pool. Because concentrations of dissolved iron and manganese increase and DO and temperature decrease with depth in Lake Sidney Lanier, small discharges (such as 600-cfs minimum flows) from Buford Dam have higher release concentrations of metals and nutrients and lower temperatures and concentrations of DO. Larger discharges result in warmer releases with higher DO concentrations and lower dissolved metal and nutrient concentrations.

49. Estimates of Buford Dam release temperatures and DO concentrations were obtained from SAM records from a continuous monitor located in the Buford Dam tailrace. Records for July, October, and November 1971-1977 were used to make estimates of high flow and low flow values of temperature and DO for midsummer and fall (referred to as October) conditions (Table 4). These values could be characterized as typical rather than extreme.

50. October and November historical field data are combined to obtain estimates of fall release water quality parameters. Estimates for release flow nutrient concentrations and CBOD (Table 4), obtained from Willey and Huff (1978), compare favorably with stream data samples collected near the Gwinnett 
County water intake (river mile 338.0) by the Georgia DNR (1973-1981). Additional field measurements taken in fall 1984 by SAS substantiate the values used. Estimates of release concentrations of dissolved iron and manganese (Table 4) are from a letter from the USGS* and Georgia DNR data (from 1980).

51. Concentrations of water quality constituents must be specified for the lateral inflows (tributaries). RIV1Q assigns the same inflow concentrations to all lateral inflows within a given segment. Therefore, concentration estimates were obtained for each of the three segments (two segments without the rereg dam) using a flow weighted average for the tributaries within a given segment. Estimates of chemical concentrations for the tributaries were obtained from Willey and Huff (1978). Lateral inflow temperature was assumed to be approximated by the monthly average equilibrium temperature (Edinger and Geyer 1965) modified for shading. Average and extreme values of monthly average, modified, equilibrium temperatures on the Chattahoochee River were developed by Benedict (1980b). Averages of the extreme and average monthly values for July and October-November were used in the model to characterize thermally stressful lateral inflow conditions. Lateral inflow concentrations of DO were assumed to be at saturation values with respect to lateral inflow temperatures. Lateral inflow concentrations used for all simulations are shown in Table 5. When the rereg dam was not included in a simulation, segment 2 was the upstream segment; thus, only the second and third values shown in Table 5 were used for a given constituent.

\section{$\underline{\text { Rate Coefficients }}$}

52. Most rate coefficients (Table 6) and/or guidance in determining them were reported by Miller and Jennings (1979), Willey and Huff (1978), Bedford, Sykes, and Libicki (1982), and Roesner, Giguere, and Evanson (1977). Manganese and iron oxidation rates were determined by examining iron and manganese concentrations measured by the USGS* at multiple river stations just below Buford Dam. Knowing changes in concentration over distance, distance between stations, and flows made it possible to estimate travel times and, thence, oxidation rates in the river.

* US Geological Survey. 1978. Water Quality Data, Chattahoochee River, 1977. Letter of 15 Feb 1978 transmitted by the US Geological Survey, Doraville, GA, to US Army Engineer District, Mobile, Mobile, AL. 


\section{PART V: SIMULATION RESULTS}

\section{General Considerations}

53. Results of numerous simulations are presented to consider effects of a proposed rereg dam on water quality during the months of July and October and under current and future water supply needs and routings. Two specific nodes were selected as sites for making comparisons of results. The first corresponds to the location of the intake for the trout hatchery (river mile 346.8). This site was chosen because of concerns voiced about quality of water supplied to the trout hatchery and potential extra treatment costs; the site is also important as it lies in the rereg pool. The second node selected, Peachtree Creek, the last model node, represents the terminus of this environmentally sensitive reach of the Chattahoochee River where several targets and objectives are specified by MAAWRMS (1981). In addition to 8-day time history plots of water quality parameters at the two nodes, average concentrations for each 8-day simulation are plotted along the river, allowing examination of changes with distance.

54. Results of certain simulations prove quite similar. Therefore, this study does not present all scenarios in the same detail; only figures depicting average values may appear for some projected operations. Omitting some of the results makes it easier to focus on flow regimes that result in significant differences in water quality conditions.

55. Results appear as a series of plots depicting water quality conditions for various operational alternatives for both July and October simulations. Only results for temperature, DO, iron, and manganese are shown as they are the water quality parameters which may create problem conditions with the addition of the rereg dam.

\section{Basic 1-Day Rereg Versus MFSF}

56. As shown previously, the 1-day rereg and the MFSF options have quite similar flow regimes (Figure 10); the only major difference is between unsteady and steady releases at Morgan Falls Dam. Likewise, water quality predictions are almost identical; temperatures rise from about $11^{\circ} \mathrm{C}$ at Buford Dam to about $20^{\circ} \mathrm{C}$ in July and from about $14^{\circ} \mathrm{C}$ to about $18^{\circ} \mathrm{C}$ in October 
(Figures 11 and 12). Variations in other water quality parameters appear undifferentiable.

\section{Hydropower Versus Nonhydropower Rereg Dam Options}

57. The original concept for a basic 1-day water supply rereg dam below Buford Dam does not consider incorportion of hydropower; as stated earlier, the basic 2.5-day water supply rereg dam is proposed as a hydropower option. Additional simulations consider the effects on water quality of a 2.5-day rereg dam without hydropower and a 1-day rereg dam with hydropower. Comparisons are made between both 1- and 2.5-day hydropower options and between both 1 - and 2.5-day nonhydropower options. Modifying simulation conditions to perform these additional tests is rather simple; one need only include or delete structural reaeration at the rereg dam to eliminate or simulate, respectively, the hydropower option. Hydropower or nonhydropower alternatives do not change flow regimes for either the 1- or the 2.5-day rereg options.

58. Figures 13 and 14 compare July and October simulations for hydropower generation with either dam alternative. Average water temperatures differ slightly near the downstream boundary (less than $0.5^{\circ} \mathrm{C}$ in July and October); otherwise, temperature simulations appear nearly identical to each other and to the previous simulations. DO, dissolved iron, and manganese concentrations also appear quite similar, although the upstream DO averages are unlike the previous figures because of the absence of structural reaeration at the rereg dam.

59. Likewise, comparing the nonhydropower options for either dam alternative reveals no differences other than the same minor average water temperature deviations (Figures 15 and 16). The jump in DO of about $2 \mathrm{mg} / \mathrm{l}$ due to structural reaeration at the rereg dam is apparent.

60. These results enable the use of the basic 1-day rereg (nonhydropower) and the basic 2.5-day rereg (hydropower) options as examples in further comparisons, since significant water quality differences occur between the hydropower and nonhydropower alternatives and not between the pools of different storage capacities studied here. These differences, caused by reaeration in the nonhydropower options, are discussed in following sections. 
61. Another operational alternative to the basic 2.5-day water supply rereg option ( 0 -cfs minimum flow) considers the effects of maintaining minimum releases of $600 \mathrm{cfs}$ from Buford Dam (alternate 2.5-day rereg). Figures 17 and 18 compare average July and October water quality simulations derived from the basic and alternate 2.5 -day rereg operations.

62. Average values for July simulations (Eigure 17) indicate that temperatures and DO concentrations are generally lower (about $1^{\circ} \mathrm{C}$ and less than $1 \mathrm{mg} / \mathrm{l}$, respectively) with the alternative option; average temperature plots converge below Morgan Falls Dam. Upstream DO concentrations are somewhat lower due to the 600-cfs minimum flows. Dissolved iron and manganese concentrations are similar and very low in July.

63. October temperature and DO averages (Figure 18) diverge slightly more than those for July. Temperature differences persist below Morgan Falls; Do differences, greater at the outset, converge about the same location as in July. Plots of dissolved iron and manganese concentrations, higher in the rereg pool under the 600-cfs minimum flow alternative, nevertheless, converge before passing through the rereg dam.

64. In July, at the trout hatchery (Figure 19), the 600-cfs low flows drive the temperature below $10^{\circ} \mathrm{C}$ and DO concentrations toward $5 \mathrm{mg} / \mathrm{l}$. Dissolved iron and manganese remain low during this period. At Peachtree Creek (Figure 20), little difference can be found between the two simulations.

65. In October, minimum flow releases of $600 \mathrm{cfs}$ cause the DO to fall below $2.0 \mathrm{mg} / \mathrm{l}$ (for aproximately two full days during the weekend) at the trout hatchery (Figure 21). With 0-cfs minimum flow, DO remains around $4 \mathrm{mg} / \mathrm{l}$. Dissolved manganese, rising to about $0.5 \mathrm{mg} / \mathrm{l}$, and dissolved iron, rising to about $1 \mathrm{mg} / \mathrm{l}$, are also somewhat higher as a result of the 600-cfs releases. Temperature, DO, dissolved iron and manganese values at Peachtree Creek (Figure 22) are comparable during the 8-day simulation period under the two flow regimes.

\section{MIP Versus Three Reregulation Options}

66. Three rereg options stand out as examples of how different rereg and operational alternatives can affect water quality simulations; these are 
the basic 1-day water supply rereg option, the alternate 1-day water supply modification (600-cfs minimum flow), and the basic 2.5-day water supply option (hydropower rereg). This section compares these options with the MIP unreregulated flow (current needs; existing, authorized operations) alternative.

67. Figure 23 shows differences in average simulated July water quality conditions between the MIP unreregulated flow and three rereg operational alternatives. Roughly speaking, the MIP alternative sustains the lowest average temperatures, followed, in order, by the alternate 1-day water supply option, the 2.5-day rereg, and the 1-day rereg. The alternate 1-day water supply option produces temperatures averaging about $0.5^{\circ} \mathrm{C}\left(1^{\circ} \mathrm{F}\right)$ less than the other rereg options. Average DO values all exceed $5 \mathrm{mg} / \ell$. Significant differences exist in the vicinity of the proposed rereg site; DO concentrations with the basic 1-day rereg or alternate 1-day options jump 2 to $2.5 \mathrm{mg} / \mathrm{l}$ as a result of structural reaeration during passage through the dam, while the MIP and the 2.5-day rereg options experience only stream or wind reaeration in this area. Dissolved iron and manganese concentrations remain low and continually decline moving downstream.

68. Figures 24 and 25 demonstrate dynamic changes in water quality variables during the 8-day July simulation period at the trout hatchery and Peachtree Creek. Water quality at the trout hatchery (Figure 24) closely follows that in releases from Buford Dam. Daily hydropower generation flows cause the water quality variables to exhibit cyclical changes. Low flows of 600 cfs from Buford Dam associated with the MIP and alternate 1-day water supply operations (and Monday morning low flows with the 2.5-day rereg option) drive the temperature below $10.0^{\circ} \mathrm{C}\left(50^{\circ} \mathrm{F}\right)$ because of the deep, cool hypolimnetic waters released; the 1 - and 2.5-day rereg options have 0 -cfs minimum flows. During periods of high release flows, temperatures are identical. The only other significant temperature effect is the weekend rise in temperature associated with the 2.5-day rereg option which has no weekend hydropower generation at Buford Dam. Highest temperatures at the trout hatchery in July do not exceed $13.0^{\circ} \mathrm{C}\left(55^{\circ} \mathrm{F}\right)$. DO concentrations at the trout hatchery are greater than $5.0 \mathrm{mg} / \mathrm{l}$ for all four simulations, with the MIP consistently the highest and the alternate. 1 -day water supply option falling toward $5.0 \mathrm{mg} / \ell$ with low flows. Pulsing manganese and iron concentrations are always low during July.

69. At Peachtree Creek (Figure 25), simulated water temperatures for 
July tend to stay at or above $18.8^{\circ} \mathrm{C}\left(66^{\circ} \mathrm{F}\right)$; they never exceed $23.3^{\circ} \mathrm{C}$ $\left(74^{\circ} \mathrm{F}\right)$. DO concentrations remain above $9.0 \mathrm{mg} / \ell$, and dissolved iron and manganese are negligible. Daily oscillations in temperature and DO primarily result from solar heating and photosynthesis, respectively.

70. In October (Figure 26), average water quality parameters follow similar trends to those in July; temperature and DO generally increase downstream, and dissolved iron and manganese decrease. Although the average water temperature of October Buford Dam releases (approximately $13.8^{\circ} \mathrm{C}\left(57^{\circ} \mathrm{F}\right)$ ) is higher than those of July, the rate of temperature increase is lower, and average temperatures do not exceed $18.8^{\circ} \mathrm{C}\left(66^{\circ} \mathrm{F}\right)$. Average Do concentrations in the rereg pool (or upstream of the rereg site in the MIP simulation) are generally less than $5.0 \mathrm{mg} / \mathrm{l}$. In the 1 - and 2.5 -day rereg options, average DO exceeds $5.0 \mathrm{mg} / \mathrm{l}$ before release from the rereg dam. MIP and alternate 1-day water supply options with low-flow releases of hypolimnetic water $(D O=1.0$ $\mathrm{mg} / \mathrm{l}$ ) remain low above river mile 342 (in the rereg pool). Passage through the rereg dam reaerates the water in the basic 1-day and alternate 1-day water supply option simulations. Average dissolved iron and manganese concentrations for the MIP option are higher than any rereg option. In the alternate 1-day water supply option simulation, average dissolved iron and manganese concentrations are relatively high in the rereg pool but approach the averages for the basic 1- and 2.5-day rereg simulations below the dam.

71. At the trout hatchery in October (Figure 27), all temperatures remain well below the $18.3^{\circ} \mathrm{C}\left(65^{\circ} \mathrm{F}\right)$ criterion, with the $1-$ and 2.5 -day rereg temperatures most stable; while low flows associated with the MIP and alternate 1-day water supply simulations lower temperatures. For the most part, DO concentrations stay below $5.0 \mathrm{mg} / \mathrm{l}$; the 600-cfs minimum flows in the alternate 1 -day water supply simulation drive DO, toward $2.0 \mathrm{mg} / \ell$. Dissolved iron and dissolved manganese concentrations in the four simulations vary considerably with the MIP option generating concentrations of $0.75 \mathrm{mg} / \mathrm{l}$ dissolved iron and $1.4 \mathrm{mg} / \mathrm{l}$ manganese; the alternate 1-day water supply option produces the second highest levels of dissolved iron and manganese. Low flow releases of the alternate 1-day water supply and MIP options drive the concentrations up daily and on Monday mornings with the 2.5-day rereg proposal.

72. At Peachtree Creek (Figure 28 ), temperatures oscillate near $18.8^{\circ} \mathrm{C}$ $\left(66^{\circ} \mathrm{F}\right)$ for all simulations, generally staying below this temperature. DO is high, and dissolved iron and manganese coricentrations are low for all 
simulations. The ranges of variation for temperature and DO at Peachtree Creek in October are less than in July due to warmer Buford Dam releases, less impact of solar heating, and less photosynthesis.

\section{Plan B Versus Three Reregulation Options}

73. Plan $B$ operations are designed to fill estimated future water supply needs for the Atlanta region. These needs entail increased withdrawals from the Chattahoochee River, additional weekend hydropower releases from Buford Dam, and daily peaking hydropower releases from Morgan Falls Dam. Thus, total releases under Plan B significantly exceed MIP releases, and these operational differences affect water quality along the study reach.

74. During July (Figure 29), average Plan B water temperatures do not exceed $18.8^{\circ} \mathrm{C}\left(66^{\circ} \mathrm{F}\right)$, as they do under other simulations, including MIP. Average DO remains above $5 \mathrm{mg} / \mathrm{l}$ while average metal concentrations exceed those experienced with rereg alternatives; these concentrations are not high enough to generate concern.

75. In July, at the trout hatchery intakes (Figure 30), modeled water temperatures remain well below $18.3^{\circ} \mathrm{C}\left(65^{\circ} \mathrm{F}\right)$. Plan B temperatures cycle between $9^{\circ}$ and $11^{\circ} \mathrm{C}$; the higher value equal to the high flow values for the rereg alternatives; the 600-cfs alternate 1-day water supply low flows drive temperatures down toward the Plan B lows. Plan B DO concentrations vary between 6.5 and $7.5 \mathrm{mg} / \mathrm{l}$, generally remaining slightly higher than those of the rereg options. Although the Plan B simulated dissolved iron and manganese, concentrations are marginally higher than the others associated with the other options. All metal concentrations are low in the relatively well-oxygenated flows from Buford Dam.

76. At Peachtree Creek, Plan B water temperatures exceed $18.8^{\circ} \mathrm{C}$ $\left(66^{\circ} \mathrm{F}\right)$ during only one daily cycle (on Tuesday), unlike the rereg flows which tend to remain above $18.8^{\circ} \mathrm{C}\left(66^{\circ} \mathrm{F}\right)$ (Figure 31$)$. Do concentrations in July remain high during the simulation period, and dissolved metal concentrations are close to zero.

77. In October, average simulated water temperatures never exceed $18.8^{\circ} \mathrm{C}\left(66^{\circ} \mathrm{F}\right) ; \mathrm{Plan} \mathrm{B}$ averages are lowest (Figure 32$)$. Average DO concentrations are very low in the area to be impounded by the proposed rereg dam, with alternate 1 -day water supply and Plan $B$ alternatives exhibiting the 
lowest averages (less than $2.0 \mathrm{mg} / \ell$ ) in this sector. Dissolved metal concentrations are relatively high in conjunction with the alternate 1-day water supply and Plan B options.

78. At the trout hatchery (Figure 33), Plan B water temperatures vary from $11.1^{\circ}$ to $13.8^{\circ} \mathrm{C}\left(52^{\circ}\right.$ to $\left.57^{\circ} \mathrm{F}\right)$; the other simulations remain around $13.8^{\circ} \mathrm{C}\left(57^{\circ} \mathrm{F}\right)$, with the alternate 1-day water supply option dropping almost as low as Plan B just prior to generation. Plan B DO concentrations are quite similar to the others, except for the alternate 1-day water supply option which tends to have less DO because of its 600-fs minimum flows. Dissolved iron and manganese concentrations under the Plan $B$ alternative are highest alternating between 0.8 and $0.3 \mathrm{mg} / \ell$ dissolved manganese and 1.4 and $0.5 \mathrm{mg} / \mathrm{l}$ iron.

79. Water temperatures at Peachtree Creek (Figure 34) rarely exceed $18.8^{\circ} \mathrm{C}\left(66^{\circ} \mathrm{F}\right)$; Plan B seems to generally exhibit the coolest temperatures. DO concentrations for Plan B and the other options stay around 9 to $10 \mathrm{mg} / \ell$. Dissolved iron and manganese concentrations are highest with Plan $B$, but the overall level is quite low. 
80. Because of the number and variety of figures and simulations presented, the large amount of information is presented in three tables addressing major study concerns: temperature, DO, and dissolved metals. These tables will not substitute for the detailed descriptions which this study's figures provide. It should be reemphasized that meteorologically stressful (3T10) conditions are used in generating these results.

81. Another concern investigated in this study is the percent of time that $18.8^{\circ} \mathrm{C}\left(66^{\circ} \mathrm{F}\right)$ is exceeded at Peachtree Creek by the various alternatives modeled (Table 7). During July, all rereg alternatives exceed this criterion a majority of the time, as does the MIP. In October, exceedances occur less frequently, and the alternate 1- and 2.5-day rereg simulations are comparable to the unreregulated systems, in frequency of exceedance of $18.8^{\circ} \mathrm{C}$ $\left(66^{\circ} \mathrm{F}\right)$.

82. Table 8 qualitatively summarizes simulation results of special interest. In none of the scenarios modeled does water temperature at Peachtree Creek exceed $23.3^{\circ} \mathrm{C}\left(74^{\circ} \mathrm{F}\right)$. Plan B is the only regime which does not experience temperatures greater than $18.8^{\circ} \mathrm{C}\left(66^{\circ} \mathrm{F}\right)$ on regular basis in July. DO concentrations in October are lowest under the alternate 1- and 2.5-day water supply rereg options due to their minimum flow releases of $600 \mathrm{cfs}$; Plan $B$ releases from Buford Dam are low in DO $(1 \mathrm{mg} / \mathrm{l})$ but reaerate rapidly to approximately $4 \mathrm{mg} / \ell$ at the trout hatchery, the same concentration that is associated with reregulation scenarios. Dissolved metal concentrations are highest for operations without a rereg dam in place.

83. Several significant conclusions can be drawn from this study. Foremost is the observation that stream temperatures under the proposed reregulation conditions would generally be warmer than the proposed unreregulated conditions; largest temperature differences occur between 0 -cfs minimum flow rereg options and unreregulated options with 600-cfs minimum flows; temperature differences are not as great with rereg options that maintain 600-cfs minimum flows; the rereg dam itself does not cause water temperatures to increase significantly, but it does store relatively warm waters released under high-flow conditions from Buford Dam. Second, rereg operations with 0 -cfs minimum flows can improve water quality in terms of increasing DO concentrations in the rereg pool region and decreasing concentrations of 
dissolved metals. Third, rereg operations with 600-cfs minimum flows may lower temperatures in summer, but they also lower DO and raise dissolved metal concentrations during fall. Fourth, with respect to effects on water quality, the size of the rereg pool is not as important as the choice between hydropower and nonhydropower structures and their associated flow regimes.

84. Simulated reregulated water temperatures may be nearly $5.0^{\circ} \mathrm{C}$ $\left(9^{\circ}\right.$ F) warmer than unreregulated temperatures at Peachtree Creek at the same point in time (Figure 31). Discrepancies of this magnitude result in part from phase differences in transient high and low flows as well as from different flow volumes. It should be recognized that temperature depends strongly upon variable conditions associated with meteorology and flow regimes at the three dams. For the stressful (3T10) conditions imposed, the maximum temperatures computed at Peachtree Creek never exceed the $23.3^{\circ} \mathrm{C}\left(74^{\circ} \mathrm{F}\right)$ criterion required by MAAWRMS. With reregulation; water temperatures frequently exceed $18.8^{\circ} \mathrm{C}\left(66^{\circ} \mathrm{F}\right)$ during stressful (3T10) July conditions, while $18.8^{\circ} \mathrm{C}\left(66^{\circ} \mathrm{F}\right)$ is rarely exceeded under future conditions without reregulation (Plan $B$ ). Records indicate that stream temperatures exceed $18.8^{\circ} \mathrm{C}\left(66^{\circ} \mathrm{F}\right)$ under existing conditions.

85. The MAAWRMS (1981) has a maximum temperature criterion of $18.3^{\circ} \mathrm{C}$ $\left(65^{\circ} \mathrm{F}\right)$ at the trout hatchery water intake. This condition is never exceeded for any of the simulations and should not be a problem with or without reregulation.

86. Results indicate that DO will not be a serious problem downstream of the rereg pool, but it could be a concern in the rereg pool. Although much less reaeration occurs in the rereg pool relative to the river, nonhydropower releases from the rereg dam should provide a very substantial amount of reaeration. Do conditions below the rereg dam without hydropower should be at least as good as present conditions or future conditions without reregulation. Severely low DO conditions are not expected to exist in the rereg pool during summer months, but may occur in the fall due to the release of low DO waters and higher concentrations of oxygen demanding materials.

87. Downstream of the rereg dam, there should be relatively little difference in dissolved iron and manganese among the various reregulation alternatives, and these alternatives result in significantly lower dissolved metal concentrations than conditions without a rereg dam. In the rereg pool, these metal concentrations should be less with reregulation, assuming that 
minimum flows from Buford Dam are eliminated (0-cfs minimum flow). October's 600-cfs minimum flow releases allow dissolved iron concentrations to exceed $1 \mathrm{mg} / \mathrm{l}$ at the trout hatchery. Of course, the highest concentrations of these materials occur during the fall when anoxic conditions usually exist in the hypolimnion of Lake Sidney Lanier.

88. Computed concentrations for other water quality parameters do not present any reason for concern. The concentrations are quite similar for conditions with and without the rereg dam and generally reflect present concentrations in the river. Under present conditions, concentrations of algae are low (Miller and Jennings 1979, Willey and Huff 1978) and have little impact on the concentrations of other constituents. These simulations indicate similar results for all conditions.

89. The following conclusions should be kept in mind when considering design or operations alternatives:

a. Impacts of water quality in Buford Dam releases can be observed throughout the study reach.

b. Differences between hydropower and nonhydropower designs for the proposed rereg dam are more important than pool size in terms of impact on water quality.

c. Increasing flow throughout the system reduces adverse water quality conditions.

d. Elimination of minimum flows from Buford Dam improves water quality in terms of dissolved metals and oxygen, but also eliminates the coldest water.

90. Maintaining operational flexibility will be important if the decision is made to construct a rereg dam. When it is feasible, those responsible for dam operations should consider varying flow regimes during the year to alleviate or minimize potential water quality problems. 
Bedford, K. W., Sykes, R. M., and Libicki, C. 1982. "A Dynamic, OneDimensional, Riverine Water Quality Model," prepared by Ohio State University under Contract No. DACW39-82-M-3548 for the US Army Engineer Waterways Experiment Station, Vicksburg, MS.

Benedict, B. A. 1980a. "Behavior of Temperature and Other Water Quality Constituents Inside Possible Reregulation Reservoir Below Buford Dam with Effect on Downstream Conditions," US Army Engineer District, Savannah, Savannah, GA.

- 1980b. "Assessment of Potential Impact of Reregulation Dam on Temperature Structure of Chattahoochee River Below Buford Dam," US Army Engineer District, Savannah, Savannah, GA.

Edinger, J. E., and Geyer, J. C. 1965. "Heat Exchange in the Environment," Publication No. 65-902, Edison Electric Institute, New York.

Faye, R. E., and Cherry, R. N. 1980. "Channel and Dynamic Flow Characteristics of the Chattahoochee River, Buford Dam to Georgia Highway 141," Geological Survey Water-Supply Paper 2063, US Government Printing Office, Washington, DC.

Fischer, H. B. 1973. "Longitudinal Dispersion and Turbulent Mixing in Open Channel Flow," Annual Review of Fluid Mechanics, pp 57-98.

Fread, D. L. 1978. "DAMBRK: The NWS Dam-Break Flood Forecasting Model," Office of Hydrology, National Weather Service, Silver Spring, MD.

Georgia Department of Natural Resources. 1973-1981. "Water Quality Monitoring Data for Georgia Streams," Environmental Protection Division, Atlanta, GA.

1980. "Water Quality and Aquatic Community Investigations in the Chattahoochee River Below Buford Dam," prepared under Contract No. DACW01-77C-0166, Environmental Protection Division, US Army Corps of Engineers, Atlanta, Georgia.

Holly, R. M., and Preissmann, A. 1978. "Accurate Calculation of Transport in Two Dimensions," Journal of Hydraulics Division, American Society of Civil Engineers, Vol 103, No. HY11, pp 1259-1277.

Jobson, H. E., and Keefer, T. N. 1979. "Modeling Highly Transient Flow, Mass, and Heat Tansport in the Chattahoochee River near Atlanta, Georgia," Geological Survey Professional Paper 1136, US Government Printing Office, Washington, DC.

Metropolitan Atlanta Area Water Resources Management Study Group. 1981. "Final Report and Final Environmental Impact Statement," US Army Engineer District, Savannah, Savannah, GA.

Miller, J. E., and Jennings, M. E. 1979. "Modeling Nitrogen, Oxygen, Chattahoochee River, Ga.," Proceedings, Environmental Engineering Division, American Society of Civil Engineers, Vol 105, No. EE4, pp 641-653.

O'Connor, D. J. 1983. "Wind Effects on Gas-Liquid Transfer Coefficients," Journal, Environmental Engineering Division, American Society of Civil

Engineers, Vol 109, pp 731-752. 
Roesner, L. A., Giguere, P. R., and Evenson, D. E. 1977 (revised 1981). "Computer Program Documentation for the Stream Quality Model Qual-II," EPA 600/9-81-014, prepared by Water Resources Engineers, Inc., Walnut Creek, CA, for Southeast Michigan Council of Governments, US Environmental Protection Agency.

Tsivoglou, E. C., and Wallace, J. R. 1972. "Characterization of Stream Reaeration Capacity," Ecological Research Service EPA-R3-72-012, Office of Research and Monitoring, US Environmental Protection Agnecy, Washington, DC.

US Geological Survey. 1972. "Traveltime Chattahoochee River, Buford Dam to Franklin, Georgia," US Geological Survey, Doraville, GA.

Willey, R. G., and Huff, D. 1978. "Chattahoochee River Water Quality Analysis," US Army Engineer Hydrologic Engineering Center, Davis, CA.

Wilhelms, S. C., and Smith, D. R. 1981 (Mar). "Reaeration Through GatedConduit Outlet Works," Technical Report E-81-5, US Army Engineer Waterways Experiment Station, Vicksburg, MS. 
Table 1

Initial Conditions Data for RIVIH, MIP and Plan $B^{* *}$ Unreregulated Flow Regimes

\begin{tabular}{|c|c|c|c|c|c|c|c|c|c|}
\hline Feature & $\begin{array}{l}\text { Distance } \\
\text { to Next } \\
\text { Node, ft } \\
\end{array}$ & $\begin{array}{l}\text { Initial } \\
\text { Flow } \\
\text { cfs } \\
\end{array}$ & $\begin{array}{c}\text { Initial } \\
\text { Depth } \\
\text { ft } \\
\end{array}$ & $\begin{array}{c}\text { Lateral Inflow } \\
\mathrm{ft}^{2} / \mathrm{sec}\end{array}$ & $\begin{array}{l}\text { Bed } \\
\text { Elevation } \\
\text { ft, NGVD } \\
\end{array}$ & \multicolumn{3}{|c|}{ Coefficients } & $\begin{array}{c}\text { Manning's } \\
\mathrm{n}\end{array}$ \\
\hline $\begin{array}{l}\text { Buford Dam } \\
\text { Richland Creek } \\
\text { Trout Hatchery } \\
\text { James Creek }\end{array}$ & $\begin{array}{l}4,646.0 \\
4,752.0 \\
3,802.0 \\
1,478.0 \\
3,432.0\end{array}$ & $\begin{array}{l}554.03 \\
563.55 \\
576.15 \\
576.20 \\
584.48\end{array}$ & $\begin{array}{l}1.48 \\
1.63 \\
4.55 \\
6.40 \\
8.05\end{array}$ & $\begin{array}{l}0.0000 \\
0.0002 \\
0.0000 \\
0.0000 \\
0.0007\end{array}$ & $\begin{array}{l}910.04 \\
903.77 \\
898.75 \\
896.75 \\
895.00\end{array}$ & $\begin{array}{r}266.0 \\
256.0 \\
170.0 \\
202.0 \\
0.0\end{array}$ & $\begin{array}{l}1.65 \\
0.58 \\
0.26 \\
2.00 \\
4.99\end{array}$ & $\begin{array}{l}2.0 \\
2.0 \\
2.0 \\
2.0 \\
2.0\end{array}$ & $\begin{array}{l}0.060 \\
0.051 \\
0.026 \\
0.030 \\
0.030\end{array}$ \\
\hline Level Creek & $\begin{array}{l}3,749.0 \\
2,957.0 \\
2,059.0 \\
3,538.0 \\
2,851.0\end{array}$ & $\begin{array}{l}603.93 \\
603.89 \\
603.89 \\
603.91 \\
617.00\end{array}$ & $\begin{array}{l}4.24 \\
4.61 \\
2.39 \\
2.91 \\
2.72\end{array}$ & $\begin{array}{l}0.0000 \\
0.0000 \\
0.0000 \\
0.0000 \\
0.0002\end{array}$ & $\begin{array}{l}898.50 \\
898.00 \\
900.00 \\
899.00 \\
898.88\end{array}$ & $\begin{array}{l}156.0 \\
191.0 \\
232.0 \\
190.0 \\
175.0\end{array}$ & $\begin{array}{l}1.23 \\
0.92 \\
2.87 \\
1.57 \\
1.00\end{array}$ & $\begin{array}{l}2.0 \\
2.0 \\
2.0 \\
2.0 \\
2.0\end{array}$ & $\begin{array}{l}0.030 \\
0.030 \\
0.030 \\
0.030 \\
0.040^{*}\end{array}$ \\
\hline $\begin{array}{l}\text { Suwannee Creek } \\
\text { Gwinnett County Water Intake }\end{array}$ & $\begin{array}{l}6,019.0 \\
5,280.0 \\
6,494.0 \\
4,541.0 \\
4,435.0\end{array}$ & $\begin{array}{l}633.38 \\
645.72 \\
645.74 \\
741.47 \\
829.18\end{array}$ & $\begin{array}{l}3.59 \\
3.81 \\
5.31 \\
3.27 \\
2.61\end{array}$ & $\begin{array}{r}0.0002 \\
0.0000 \\
0.0000 \\
0.0012 \\
-0.0036(-0.0027) * *\end{array}$ & $\begin{array}{l}895.60 \\
891.47 \\
887.83 \\
889.44 \\
889.50\end{array}$ & $\begin{array}{l}174.0 \\
160.0 \\
155.0 \\
154.0 \\
166.0\end{array}$ & $\begin{array}{l}1.39 \\
1.46 \\
1.35 \\
2.31 \\
1.12\end{array}$ & $\begin{array}{l}2.0 \\
2.0 \\
2.0 \\
2.0 \\
2.0\end{array}$ & $\begin{array}{l}0.060^{*} \\
0.070^{*} \\
0.030 \\
0.020 \\
0.026\end{array}$ \\
\hline Johns Creek & $\begin{array}{r}6,019.0 \\
3,960.0 \\
13,200.0 \\
5,438.0 \\
5,491.0\end{array}$ & $\begin{array}{l}1,066.23 \\
1,086.38 \\
1,086.39 \\
1,086.41 \\
1,086.66\end{array}$ & $\begin{array}{l}5.13 \\
4.67 \\
6.22 \\
2.27 \\
2.81\end{array}$ & $\begin{array}{l}0.0000 \\
0.0000 \\
0.0001 \\
0.0000 \\
0.0000\end{array}$ & $\begin{array}{l}876.31 \\
875.92 \\
874.01 \\
868.60 \\
865.11\end{array}$ & $\begin{array}{l}187.0 \\
182.0 \\
144.0 \\
222.0 \\
238.0\end{array}$ & $\begin{array}{l}0.37 \\
2.38 \\
1.92 \\
1.59 \\
1.21\end{array}$ & $\begin{array}{l}2.0 \\
2.0 \\
2.0 \\
2.0 \\
2.0\end{array}$ & $\begin{array}{l}0.050 \\
0.050^{*} \\
0.042 \\
0.042 \\
0.042\end{array}$ \\
\hline
\end{tabular}

(Continued)

\footnotetext{
* Variable Manning's n's were used.

* Modified Interim Plan and Plan B (in parentheses).
} 
Table 1 (Concluded)

\begin{tabular}{|c|c|c|c|c|c|c|c|c|c|}
\hline Feature & $\begin{array}{l}\text { Distance } \\
\text { to Next } \\
\text { Node, ft }\end{array}$ & $\begin{array}{l}\text { Initial } \\
\text { Flow } \\
\text { cfs } \\
\end{array}$ & $\begin{array}{l}\text { Initial } \\
\text { Depth } \\
\text { ft } \\
\end{array}$ & $\begin{array}{c}\text { Lateral Inflow } \\
\mathrm{ft}^{2} / \mathrm{sec} \\
\end{array}$ & \begin{tabular}{l}
\multicolumn{1}{c}{ Bed } \\
Elevation \\
$\mathrm{ft}$, NGVD \\
\end{tabular} & \multicolumn{3}{|c|}{ Coefficients } & $\begin{array}{c}\text { Manning's } \\
\mathrm{n}\end{array}$ \\
\hline $\begin{array}{l}\text { DeKalb County Water Intake } \\
\text { Crooked Creek }\end{array}$ & $\begin{array}{l}4,013.0 \\
6,160.0 \\
6,160.0 \\
6,160.0 \\
8,888.0\end{array}$ & $\begin{array}{l}1,087 \cdot 06 \\
1,087 \cdot 30 \\
1,087 \cdot 30 \\
1,087.34 \\
1,087.90\end{array}$ & $\begin{array}{l}7.77 \\
4.20 \\
4.00 \\
2.46 \\
2.66\end{array}$ & $\begin{array}{r}-0.0409(-0.0615) * * \\
0.0000 \\
0.0000 \\
0.0004 \\
0.0000\end{array}$ & $\begin{array}{l}857.90 \\
860.50 \\
859.83 \\
859.16 \\
858.50\end{array}$ & $\begin{array}{r}0.0 \\
180.0 \\
180.0 \\
200.0 \\
212.0\end{array}$ & $\begin{array}{l}7.11 \\
1.83 \\
1.83 \\
2.52 \\
3.21\end{array}$ & $\begin{array}{l}2.0 \\
2.0 \\
2.0 \\
2.0 \\
2.0\end{array}$ & $\begin{array}{l}0.042 \\
0.042 \\
0.042 \\
0.042 \\
0.042\end{array}$ \\
\hline $\begin{array}{l}\text { Big Creek } \\
\text { Willeo Creek } \\
\text { Morgan Falls Dam }\end{array}$ & $\begin{array}{r}8,888.0 \\
8,888.0 \\
10,982.0 \\
7,550.0 \\
5,000.0\end{array}$ & $\begin{array}{l}1,087.90 \\
1,087.96 \\
1,071.11 \\
1,061.12 \\
1,044.00\end{array}$ & $\begin{array}{r}4.29 \\
11.35 \\
13.40 \\
12.70 \\
12.47\end{array}$ & $\begin{array}{l}0.0000 \\
0.0011 \\
0.0002 \\
0.0000 \\
0.0000\end{array}$ & $\begin{array}{l}854.00 \\
846.00 \\
842.01 \\
840.00 \\
840.00\end{array}$ & $\begin{array}{r}450.0 \\
210.0 \\
0.0 \\
0.0 \\
0.0\end{array}$ & $\begin{array}{r}2.73 \\
4.60 \\
22.00 \\
40.00 \\
40.00\end{array}$ & $\begin{array}{l}2.0 \\
2.0 \\
2.0 \\
2.0 \\
2.0\end{array}$ & $\begin{array}{l}0.060 \\
0.042 \\
0.025 \\
0.020 \\
0.020\end{array}$ \\
\hline $\begin{array}{l}\text { Cobb County Water Intake } \\
\text { Soap Creek }\end{array}$ & $\begin{array}{l}5,438.0 \\
5,808.0 \\
5,544.0 \\
9,979.0 \\
6,283.0\end{array}$ & $\begin{array}{l}1,044.00 \\
1,044.01 \\
1,044.02 \\
1,044.03 \\
1,044.04\end{array}$ & $\begin{array}{l}3.13 \\
2.34 \\
7.20 \\
5.74 \\
1.33\end{array}$ & $\begin{array}{r}0.0000 \\
0.0000 \\
-0.0133(-0.0209)^{* *} \\
0.0000 \\
0.0014\end{array}$ & $\begin{array}{l}794.61 \\
793.00 \\
787.00 \\
788.30 \\
785.50\end{array}$ & $\begin{array}{l}274.0 \\
274.0 \\
224.0 \\
250.0 \\
332.0\end{array}$ & $\begin{array}{l}1.67 \\
1.67 \\
2.71 \\
2.43 \\
3.56\end{array}$ & $\begin{array}{l}2.0 \\
2.0 \\
2.0 \\
2.0 \\
2.0\end{array}$ & $\begin{array}{l}0.042 \\
0.042 \\
0.042 \\
0.042 \\
0.042\end{array}$ \\
\hline $\begin{array}{l}\text { Island and Rottenwood Creeks } \\
\text { Atlanta Water Intake } \\
\text { Peachtree Creek }\end{array}$ & $\begin{array}{l}3,960.0 \\
3,538.0 \\
4,805.0 \\
5,650.0 \\
5,280.0\end{array}$ & $\begin{array}{l}1,044.03 \\
1,044.98 \\
1,044.00 \\
1,044.00 \\
1,044.00\end{array}$ & $\begin{array}{l}1.36 \\
3.03 \\
4.95 \\
4.39 \\
9.40\end{array}$ & $\begin{array}{r}0.0000 \\
0.0018 \\
0.0000 \\
-0.0439(-0.0519) \\
0.0000\end{array}$ & $\begin{array}{l}756.00 \\
750.00 \\
750.50 \\
744.00 \\
738.20\end{array}$ & $\begin{array}{l}450.0 \\
220.0 \\
175.0 \\
172.0 \\
128.0\end{array}$ & $\begin{array}{l}6.81 \\
2.07 \\
2.10 \\
3.10 \\
3.82\end{array}$ & $\begin{array}{l}2.0 \\
2.0 \\
2.0 \\
2.0 \\
2.0\end{array}$ & $\begin{array}{l}0.042 \\
0.030 \\
0.080^{*} \\
0.060 \\
0.045\end{array}$ \\
\hline
\end{tabular}

* Variable Manning's n's were used.

* Modified Interim Plan and Plan B (in parentheses). 
Table 2

Initial Conditions Data for RIV1H, Basic 1-day and 2.5-day Water Supply Reregulated Flow Regimes

\begin{tabular}{|c|c|c|c|c|c|c|c|c|c|}
\hline Eeature & \multirow{2}{*}{$\begin{array}{l}\text { Distance } \\
\text { to Next } \\
\text { Node, ft } \\
4,646.0 \\
4,752.0 \\
3,802.0 \\
1,478.0 \\
3,432.0\end{array}$} & \multirow{2}{*}{ 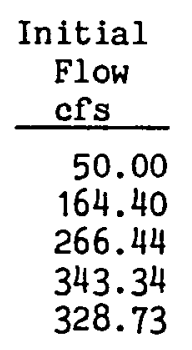 } & \multirow{2}{*}{$\begin{array}{l}\begin{array}{c}\text { Initial } \\
\text { Depth } \\
\text { ft }\end{array} \\
60(1.63) * * \\
64(8.67) \\
64(15.67) \\
89(14.92) \\
64(16.67)\end{array}$} & \multirow{2}{*}{$\begin{array}{l}\text { Lateral } \\
\text { Inflow } \\
\text { ft } \mathrm{ft}^{2} / \mathrm{sec} \\
0.0000 \\
0.0002 \\
0.0000 \\
0.0000 \\
0.0007\end{array}$} & \multirow{2}{*}{$\begin{array}{c}\text { Bed } \\
\text { Elevation } \\
\text { ft, NGVD } \\
910.04 \\
903.00 \\
896.00 \\
896.75 \\
895.00\end{array}$} & \multicolumn{3}{|c|}{ Coefficients } & \multirow{2}{*}{$\begin{array}{c}\text { Manning 's } \\
\text { n } \\
0.060 \\
0.051 \\
0.026 \\
0.030 \\
0.030\end{array}$} \\
\hline $\begin{array}{l}\text { Buford Dam } \\
\text { Richland Creek } \\
\text { Trout Hatchery } \\
\text { James Creek }\end{array}$ & & & & & & $\begin{array}{l}266.0 \\
208.0 \\
125.0 \\
202.0 \\
135.0\end{array}$ & $\begin{array}{l}1.65 \\
3.68 \\
2.08 \\
2.00 \\
5.13\end{array}$ & $\begin{array}{l}2.0 \\
2.0 \\
2.0 \\
2.0 \\
2.0\end{array}$ & \\
\hline Level Creek & $\begin{array}{l}3,749.0 \\
2,957.0 \\
2,059.0 \\
3,538.0 \\
2,851.0\end{array}$ & $\begin{array}{r}497.97 \\
680.88 \\
875.75 \\
1,019.18 \\
1,259.13\end{array}$ & $\begin{array}{ll}18.14 & (13.17) \\
21.64 & (16.67) \\
21.64 & (16.67) \\
20.64 & (15.67) \\
17.76 & (11.79)\end{array}$ & $\begin{array}{l}0.0000 \\
0.0000 \\
0.0000 \\
0.0000 \\
0.0002\end{array}$ & $\begin{array}{l}898.50 \\
895.0 \\
895.0 \\
896.00 \\
898.88\end{array}$ & $\begin{array}{r}156.0 \\
0.0 \\
0.0 \\
0.0 \\
0.0\end{array}$ & $\begin{array}{r}8.08 \\
17.00 \\
20.00 \\
20.00 \\
23.00\end{array}$ & $\begin{array}{l}2.0 \\
2.0 \\
2.0 \\
2.0 \\
2.0\end{array}$ & $\begin{array}{l}0.030 \\
0.030 \\
0.030 \\
0.030 \\
0.020\end{array}$ \\
\hline $\begin{array}{l}\text { Rereg Dam } \\
\text { Dick Creek } \\
\text { Suwannee Creek }\end{array}$ & $\begin{array}{l}5,000.0 \\
6,019.0 \\
5,280.0 \\
6,494.0 \\
4,541.0\end{array}$ & $\begin{array}{l}1,500.00 \\
1,500.00 \\
1,500.60 \\
1,500.59 \\
1,500.51\end{array}$ & $\begin{array}{r}24.64(19.67) \\
7.96 \\
3.86 \\
6.90 \\
4.81\end{array}$ & $\begin{array}{l}0.0000 \\
0.0002 \\
0.0000 \\
0.0000 \\
0.0012\end{array}$ & $\begin{array}{l}892.00 \\
892.00 \\
891.47 \\
887.83 \\
889.44\end{array}$ & $\begin{array}{r}0.0 \\
174.0 \\
160.0 \\
155.0 \\
154.0\end{array}$ & $\begin{array}{r}25.00 \\
1.39 \\
1.46 \\
1.35 \\
2.31\end{array}$ & $\begin{array}{l}2.0 \\
2.0 \\
2.0 \\
2.0 \\
2.0\end{array}$ & $\begin{array}{l}0.020 \\
0.060^{*} \\
0.070^{*} \\
0.030 \\
0.020\end{array}$ \\
\hline Gwinnett County Water Intake & $\begin{array}{l}4,435.0 \\
6,811.0 \\
2,006.0 \\
5,333.0 \\
5,914.0\end{array}$ & $\begin{array}{l}1,501.11 \\
1,495.18 \\
1,495.11 \\
1,495.12 \\
1,495.12\end{array}$ & $\begin{array}{l}4.43 \\
5.47 \\
3.35 \\
5.12 \\
4.93\end{array}$ & $\begin{array}{l}0.0027 \\
0.0000 \\
0.0000 \\
0.0000 \\
0.0000\end{array}$ & $\begin{array}{l}889.50 \\
888.09 \\
883.89 \\
881.20 \\
879.40\end{array}$ & $\begin{array}{l}166.0 \\
174.0 \\
151.0 \\
159.0 \\
145.0\end{array}$ & $\begin{array}{l}1.12 \\
2.38 \\
2.34 \\
0.88 \\
1.23\end{array}$ & $\begin{array}{l}2.0 \\
2.0 \\
2.0 \\
2.0 \\
2.0\end{array}$ & $\begin{array}{l}0.026 \\
0.050 \\
0.040^{*} \\
0.050 \\
0.040\end{array}$ \\
\hline Johns Creek & $\begin{array}{r}6,494.0 \\
6,019.0 \\
3,960.0 \\
13,200.0 \\
5,438.0\end{array}$ & $\begin{array}{l}1,495.11 \\
1,495.12 \\
1,495.11 \\
1,495.31 \\
1,495.97\end{array}$ & $\begin{array}{l}5.70 \\
6.22 \\
4.48 \\
4.70 \\
2.85 \\
\\
\text { (Continued) }\end{array}$ & $\begin{array}{l}0.0000 \\
0.0000 \\
0.0000 \\
0.0001 \\
0.0000\end{array}$ & $\begin{array}{l}877.49 \\
876.31 \\
875.92 \\
874.01 \\
868.60\end{array}$ & $\begin{array}{l}164.0 \\
187.0 \\
182.0 \\
144.0 \\
222.0\end{array}$ & $\begin{array}{l}0.32 \\
0.37 \\
2.38 \\
1.92 \\
1.59\end{array}$ & $\begin{array}{l}2.0 \\
2.0 \\
2.0 \\
2.0 \\
2.0\end{array}$ & $\begin{array}{l}0.040 \\
0.050 \\
0.050^{*} \\
0.042 \\
0.042\end{array}$ \\
\hline
\end{tabular}

* Variable Mannings n's were used.

* MIP and Plan B (in parentheses). 
Table 2 (Concluded)

\begin{tabular}{|c|c|c|c|c|c|c|c|c|c|}
\hline Feature & $\begin{array}{l}\text { Distance } \\
\text { to Next } \\
\text { Node, ft }\end{array}$ & $\begin{array}{c}\text { Initial } \\
\text { Flow } \\
\text { cfs } \\
\end{array}$ & $\begin{array}{c}\text { Initial } \\
\text { Depth } \\
\text { ft }\end{array}$ & $\begin{array}{l}\text { Lateral } \\
\text { Inflow } \\
\mathrm{ft} t^{2} / \mathrm{sec} \\
\end{array}$ & \begin{tabular}{l}
\multicolumn{1}{r}{ Bed } \\
Elevation \\
$\mathrm{ft}, \mathrm{NGVD}$ \\
\end{tabular} & \multicolumn{3}{|c|}{ Coefficients } & $\begin{array}{c}\text { Manning 's } \\
\mathrm{n}\end{array}$ \\
\hline $\begin{array}{l}\text { Johns Creek } \\
\text { DeKalb Co. Water Intake } \\
\text { Crooked Creek }\end{array}$ & $\begin{array}{l}5,491.0 \\
4,013.0 \\
6,160.0 \\
6,160.0 \\
6,160.0\end{array}$ & $\begin{array}{l}1,495.96 \\
1,327.10 \\
1,203.68 \\
1,203.53 \\
1,204.54\end{array}$ & $\begin{array}{l}3.37 \\
8.00 \\
4.15 \\
3.84 \\
3.50\end{array}$ & $\begin{array}{l}0.0000 \\
0.0615 \\
0.0000 \\
0.0000 \\
0.0004\end{array}$ & $\begin{array}{l}865.11 \\
857.90 \\
860.50 \\
859.83 \\
859.16\end{array}$ & $\begin{array}{r}238.0 \\
0.0 \\
180.0 \\
180.0 \\
200.0\end{array}$ & $\begin{array}{l}1.21 \\
7.11 \\
1.83 \\
1.83 \\
2.52\end{array}$ & $\begin{array}{l}2.0 \\
2.0 \\
2.0 \\
2.0 \\
2.0\end{array}$ & $\begin{array}{l}0.042 \\
0.042 \\
0.042 \\
0.042 \\
0.042\end{array}$ \\
\hline Big Creek & $\begin{array}{r}8,888.0 \\
8,888.0 \\
8,888.0 \\
10,982.0 \\
7,550.0\end{array}$ & $\begin{array}{l}1,205.84 \\
1,204.98 \\
1,204.70 \\
1,198.57 \\
1,169.29\end{array}$ & $\begin{array}{r}2.16 \\
4.23 \\
11.43 \\
14.00 \\
14.20\end{array}$ & $\begin{array}{l}0.0000 \\
0.0000 \\
0.0011 \\
0.0002 \\
0.0000\end{array}$ & $\begin{array}{l}858.50 \\
854.00 \\
846.00 \\
842.01 \\
840.00\end{array}$ & $\begin{array}{r}212.0 \\
450.0 \\
210.0 \\
0.0 \\
0.0\end{array}$ & $\begin{array}{r}3.21 \\
2.73 \\
4.60 \\
22.00 \\
40.00\end{array}$ & $\begin{array}{l}2.0 \\
2.0 \\
2.0 \\
2.0 \\
2.0\end{array}$ & $\begin{array}{l}0.042 \\
0.060 \\
0.042 \\
0.025 \\
0.020\end{array}$ \\
\hline Morgan Falls Dam & $5,000.0$ & $1,141.00$ & 14.00 & 0.0000 & 840.00 & 0.0 & 40.00 & 2.0 & 0.020 \\
\hline & $5,438.0$ & $1,141.00$ & 3.38 & 0.0000 & 794.61 & 274.0 & 1.67 & 2.0 & 0.042 \\
\hline & $5,808.0$ & $1,140.99$ & 2.52 & 0.0000 & 793.00 & 274.0 & 1.67 & 2.0 & 0.042 \\
\hline Cobb County Water Intake & $5,544.0$ & $1,080.32$ & 7.29 & -0.0209 & 787.00 & 224.0 & 2.71 & 2.0 & 0.042 \\
\hline & $9,979.0$ & $1,022.34$ & 5.81 & 0.0000 & 788.30 & 250.0 & 2.43 & 2.0 & 0.042 \\
\hline Soap Creek & $\begin{array}{l}6,283.0 \\
2,482.0 \\
1,293.0 \\
1,294.0 \\
2,482.0\end{array}$ & $\begin{array}{l}1,029.36 \\
1,033.73 \\
1,033.75 \\
1,033.74 \\
1,033.77\end{array}$ & $\begin{array}{l}1.36 \\
2.03 \\
1.40 \\
2.78 \\
7.77\end{array}$ & $\begin{array}{l}0.0014 \\
0.0000 \\
0.0000 \\
0.0000 \\
0.0000\end{array}$ & $\begin{array}{l}785.50 \\
776.50 \\
767.50 \\
760.70 \\
754.00\end{array}$ & $\begin{array}{r}332.0 \\
433.0 \\
387.0 \\
300.0 \\
97.0\end{array}$ & $\begin{array}{l}3.56 \\
0.83 \\
1.83 \\
1.83 \\
2.29\end{array}$ & $\begin{array}{l}2.0 \\
2.0 \\
2.0 \\
2.0 \\
2.0\end{array}$ & $\begin{array}{l}0.042 \\
0.080 \\
0.080 \\
0.070 \\
0.042\end{array}$ \\
\hline $\begin{array}{l}\text { Island and Rottenwood Creeks } \\
\text { Atlanta Water Intake } \\
\text { Peachtree Creek }\end{array}$ & $\begin{array}{l}2,904.0 \\
3,960.0 \\
3,538.0 \\
4,805.0 \\
5,650.0 \\
5,280.0\end{array}$ & $\begin{array}{r}1,033.73 \\
1,033.32 \\
1,037.32 \\
1,040.49 \\
912.81 \\
769.20\end{array}$ & $\begin{array}{l}2.14 \\
1.49 \\
5.03 \\
4.10 \\
4.20 \\
9.14\end{array}$ & $\begin{array}{r}0.0000 \\
0.0000 \\
0.0018 \\
0.0000 \\
-0.0519 \\
0.0000\end{array}$ & $\begin{array}{l}758.50 \\
756.00 \\
750.00 \\
750.50 \\
744.00 \\
738.20\end{array}$ & $\begin{array}{l}274.0 \\
450.0 \\
220.0 \\
175.0 \\
172.0 \\
128.0\end{array}$ & $\begin{array}{l}2.93 \\
6.81 \\
2.07 \\
2.10 \\
3.10 \\
3.82\end{array}$ & $\begin{array}{l}2.0 \\
2.0 \\
2.0 \\
2.0 \\
2.0 \\
2.0\end{array}$ & $\begin{array}{l}0.042 \\
0.042 \\
0.030 \\
0.080^{*} \\
0.060 \\
0.045\end{array}$ \\
\hline
\end{tabular}

* Variable Manning's n's were used 
Table 3

Descriptions of Flow Regimes Used in this Study

\begin{tabular}{|c|c|c|}
\hline Scenario & Brief Title & Description \\
\hline Modified Interim Plan & MIP & $\begin{array}{l}\text { No rereg dam; similar to present operating conditions; } 600 \text {-cfs } \\
\text { minimum flow and } 8,400 \text {-cfs maximum flow from Buford Dam; } \\
\text { weekend hydropower generation at Buford Dam; 1,054-cfs } \\
\text { steady release from Morgan Falls Dam }\end{array}$ \\
\hline MAAWRMS* Plan B & Plan $B$ & $\begin{array}{l}\text { No rereg dam; estimated future needs with reallocation of } \\
\text { storage from Buford Dam in Lake Sidney Lanier; 600-cfs mini- } \\
\text { mum flow and 5,000-cfs maximum flow from Buford Dam; daily } \\
\text { peaking releases at Morgan Falls Dam; weekend power genera- } \\
\text { tion at Buford Dam }\end{array}$ \\
\hline $\begin{array}{l}\text { Basic 1-day water } \\
\text { supply rereg option }\end{array}$ & $\begin{array}{l}\text { Basic 1-day } \\
\text { rereg }\end{array}$ & $\begin{array}{l}\text { 0-cfs minimum flow and } 8,400 \text {-cfs maximum flow from Buford Dam; } \\
\text { weekend generation at Buford Dam; weekday peaking releases } \\
\text { at Morgan Falls Dam }\end{array}$ \\
\hline $\begin{array}{l}\text { Basic } 2.5 \text {-day water } \\
\text { supply rereg option }\end{array}$ & $\begin{array}{l}\text { Basic } 2.5 \text {-day } \\
\quad \text { rereg }\end{array}$ & $\begin{array}{l}\text { 0-cfs minimum flow except for } 600 \text { cfs Monday a.m. and } \\
8,400 \text {-cfs maximum flow from Buford Dam; no weekend power } \\
\text { generation at Buford Dam; weekday peaking releases at Morgan } \\
\text { Falls Dam }\end{array}$ \\
\hline $\begin{array}{l}\text { 1-day water supply with } \\
600 \text {-cfs minimum }\end{array}$ & $\begin{array}{l}\text { Alternate } \\
1 \text {-day rereg }\end{array}$ & $\begin{array}{l}600-c f \text { minimum flow and } 8,400-\text { cfs maximum flow from Buford } \\
\text { Dam; weekend power generation at Buford Dam; weekday peaking } \\
\text { releases from Morgan Falls Dam }\end{array}$ \\
\hline $\begin{array}{l}\text { Basic 1-day water } \\
\text { supply rereg with } \\
\text { Morgan Falls steady } \\
\text { flow options }\end{array}$ & MFSF & $\begin{array}{l}\text { 0-cfs minimum flow and } 8,400 \text {-cfs maximum flow from Buford Dam; } \\
\text { weekend power generation from Buford Dam; Morgan Falls } \\
\text { steady release of } 1,263 \text { cfs }\end{array}$ \\
\hline $\begin{array}{l}\text { Alternate } 2.5 \text {-day water } \\
\text { supply rereg option }\end{array}$ & $\begin{array}{l}\text { Alternate } \\
2.5 \text {-day rereg }\end{array}$ & $\begin{array}{l}600-c f s \text { minimum flow and } 8,400-c f s \text { maximum flow from Buford } \\
\text { Dam; no weekend power generation at Buford Dam; weekday } \\
\text { peaking releases at Morgan Falls Dam }\end{array}$ \\
\hline
\end{tabular}

* Metropolitan Atlanta Area Water Resources Management Study (MAAWRMS). 
Table 4

Water Quality Boundary Conditions, Buford Dam Releases

\begin{tabular}{|c|c|c|c|}
\hline \multirow[b]{2}{*}{ Constituent } & \multirow[b]{2}{*}{ Flow* } & \multicolumn{2}{|c|}{ Month } \\
\hline & & July & October \\
\hline Temperature, ${ }^{\circ} \mathrm{C}$ & $\begin{array}{l}\text { low } \\
\text { high }\end{array}$ & $\begin{array}{r}8.6 \\
11.1\end{array}$ & $\begin{array}{l}10.6 \\
14.2\end{array}$ \\
\hline Ultimate CBOD, $\mathrm{mg} / \ell$ & & 2.0 & 2.0 \\
\hline Organic nitrogen, $\mathrm{mg} / \ell$ & $\begin{array}{l}\text { low } \\
\text { high }\end{array}$ & $\begin{array}{l}0.2 \\
0.2\end{array}$ & $\begin{array}{l}0.18 \\
0.24\end{array}$ \\
\hline Ammonia nitrogen, $\mathrm{mg} / \mathrm{l}$ & $\begin{array}{l}\text { low } \\
\text { high }\end{array}$ & $\begin{array}{l}0.13 \\
0.13\end{array}$ & $\begin{array}{l}0.32 \\
0.16\end{array}$ \\
\hline Nitrate nitrogen, $\mathrm{mg} / \mathrm{l}$ & & 0.30 & 0.10 \\
\hline Phosphate phosphorus, $\mathrm{mg} / \mathrm{l}$ & & 0.01 & 0.01 \\
\hline $\mathrm{DO}, \mathrm{mg} / \mathrm{\ell}$ & $\begin{array}{l}\text { low } \\
\text { high }\end{array}$ & $\begin{array}{l}5.0 \\
6.0\end{array}$ & $\begin{array}{l}1.0 \\
3.5\end{array}$ \\
\hline Dissolved manganese, $\mathrm{mg} / \mathrm{l}$ & $\begin{array}{l}\text { low } \\
\text { high }\end{array}$ & $\begin{array}{l}0.1 \\
0.1\end{array}$ & $\begin{array}{l}0.8 \\
0.3\end{array}$ \\
\hline Dissolved iron, $\mathrm{mg} / \ell$ & $\begin{array}{l}\text { low } \\
\text { high }\end{array}$ & $\begin{array}{l}0.2 \\
0.2\end{array}$ & $\begin{array}{l}1.5 \\
0.6\end{array}$ \\
\hline Fecal coliforms, col/100 me & & 0 & 0 \\
\hline
\end{tabular}

* Low flow $=$ minimum flow $(600 \mathrm{cfs})$; high flow $=$ peaking power flow. 
Table 5

Lateral Inflows

\begin{tabular}{|c|c|c|c|}
\hline Constituent & Segment $1^{*}$ & Segment $2^{*}$ & Segment 3t \\
\hline \multicolumn{4}{|l|}{ Temperature, deg $\mathrm{C}$} \\
\hline July & 29 & 29 & 29 \\
\hline August & 15 & 15 & 15 \\
\hline \multicolumn{4}{|l|}{ Dissolved Oxygen, $\mathrm{mg} / \mathrm{l}$} \\
\hline (July, $100 \%$ saturation) & 7.7 & 7.7 & 7.7 \\
\hline (October, $100 \%$ saturation) & 10.1 & 10.1 & 10.1 \\
\hline Ultimate CBOD, mg/l & 2.0 & 7.3 & 20.0 \\
\hline Organic nitrogen, $\mathrm{mg} / \mathrm{l}$ & 0.2 & 0.6 & 2.0 \\
\hline Ammonia nitrogen, $\mathrm{mg} / \mathrm{l}$ & 0.1 & 0.25 & 1.0 \\
\hline Nitrate nitrogen, $\mathrm{mg} / \ell$ & 0.4 & 0.5 & 0.4 \\
\hline Phosphate phosphorus, $\mathrm{mg} / \mathrm{l}$ & 0.2 & 0.25 & 1.0 \\
\hline Fecal coliforms, col/100 me & 100.0 & $3,300.0$ & $950,000.0$ \\
\hline
\end{tabular}

Segment 1 extends from Buford Dam to the rereg dam.

* Segment 2 extends from the rereg dam to Morgan Falls Dam or from Buford Dam to Morgan Falls Dam.

$t$ Segment 3 extends from Morgan Falls Dam to Peachtree Creek.

Table 6

Rate Coefficients (Base e and $11^{\circ} \mathrm{C}$ )

\begin{tabular}{|c|c|}
\hline Coefficient & Units \\
\hline $\begin{array}{l}\text { Nitrification rate } \\
\text { (ammonia to nitrate) }\end{array}$ & $0.50 /$ day \\
\hline Algal decay rate & $0.05 /$ day \\
\hline Algal growth rate & $0.005 \mathrm{sq} \mathrm{m} /$ (watts $/$ day $)$ \\
\hline Manganese oxidation rate & $0.50 /$ day \\
\hline Iron oxidation rate & $1.0 /$ day \\
\hline CBOD decay rate & $0.15 /$ day \\
\hline Coliform die-off rate & $0.75 /$ day \\
\hline Tsivoglou coefficient & $0.05 / \mathrm{ft}$ \\
\hline Bottom plant density & $\begin{array}{l}1.10 \mathrm{~g} /(\mathrm{sq} \mathrm{m}) \text { above Morgan Falls Dam } \\
4.00 \mathrm{~g} /(\mathrm{sq} \mathrm{m}) \text { below Morgan Falls Dam }\end{array}$ \\
\hline Light extinction coefficient & $0.20 / \mathrm{ft}$ \\
\hline
\end{tabular}


Table 7

Percent of Time $18.3^{\circ} \mathrm{C}$ is Exceeded at Peachtree Creek by

Various Alternatives Examined in This Study

\begin{tabular}{lcc}
\hline \multicolumn{1}{c}{ Alternative } & July & October \\
MIP & 54 & 4 \\
Plan B & 7 & 2 \\
1-day rereg & 94 & 23 \\
2.5-day rereg & 87 & 17 \\
MFSF & 96 & 30 \\
Alternate 1-day rereg & 74 & 1 \\
Alternate 2.5-day rereg & 82 & 2 \\
\end{tabular}

Table 8

Summary of Results

\begin{tabular}{|c|c|c|c|c|}
\hline Simulation & $\begin{array}{l}23.3^{\circ} \mathrm{C} \\
\text { Exceeded } \\
\text { at Peachtree } \\
\text { Creek, July } \\
\end{array}$ & $\begin{array}{l}\text { Frequency of } \\
\text { Exceeding } 18.8^{\circ} \mathrm{C} \\
\text { at Peachtree } \\
\text { Creek, July } \\
\end{array}$ & $\begin{array}{l}\text { DO is a } \\
\text { Concern } \\
\text { Oct } \\
\end{array}$ & $\begin{array}{l}\text { Concentration } \\
\text { of Fe and Mn } \\
\text { at Trout Hatchery } \\
\text { Oct } \\
\end{array}$ \\
\hline $\begin{array}{l}\text { Modified Interim } \\
\text { Plan }\end{array}$ & No & High & Some & High \\
\hline Plan B & & Low & & High \\
\hline 1 day rereg & & High & & Low \\
\hline 2.5 day rereg & & & & Low \\
\hline $\begin{array}{l}\text { Alternate } 1 \text { day } \\
\text { rereg }\end{array}$ & & & Yes & Moderate \\
\hline $\begin{array}{l}\text { Morgan Falls } \\
\text { Steady Flow }\end{array}$ & & & Some & Low \\
\hline $\begin{array}{l}\text { Alternate } 2.5 \text {-day } \\
\text { rereg }\end{array}$ & 1 & $\downarrow$ & Yes & Moderate \\
\hline
\end{tabular}




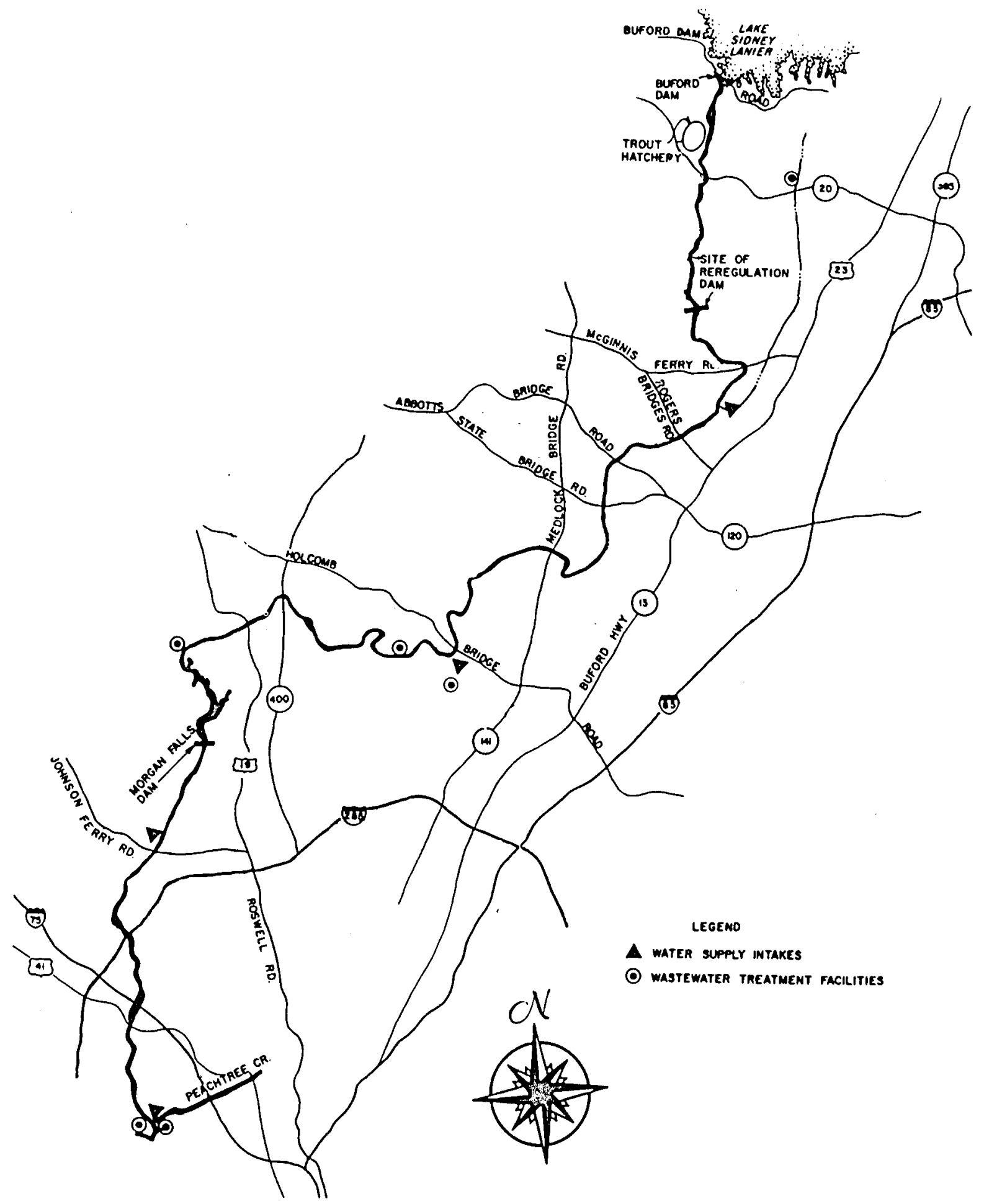

Figure 1. Location map 


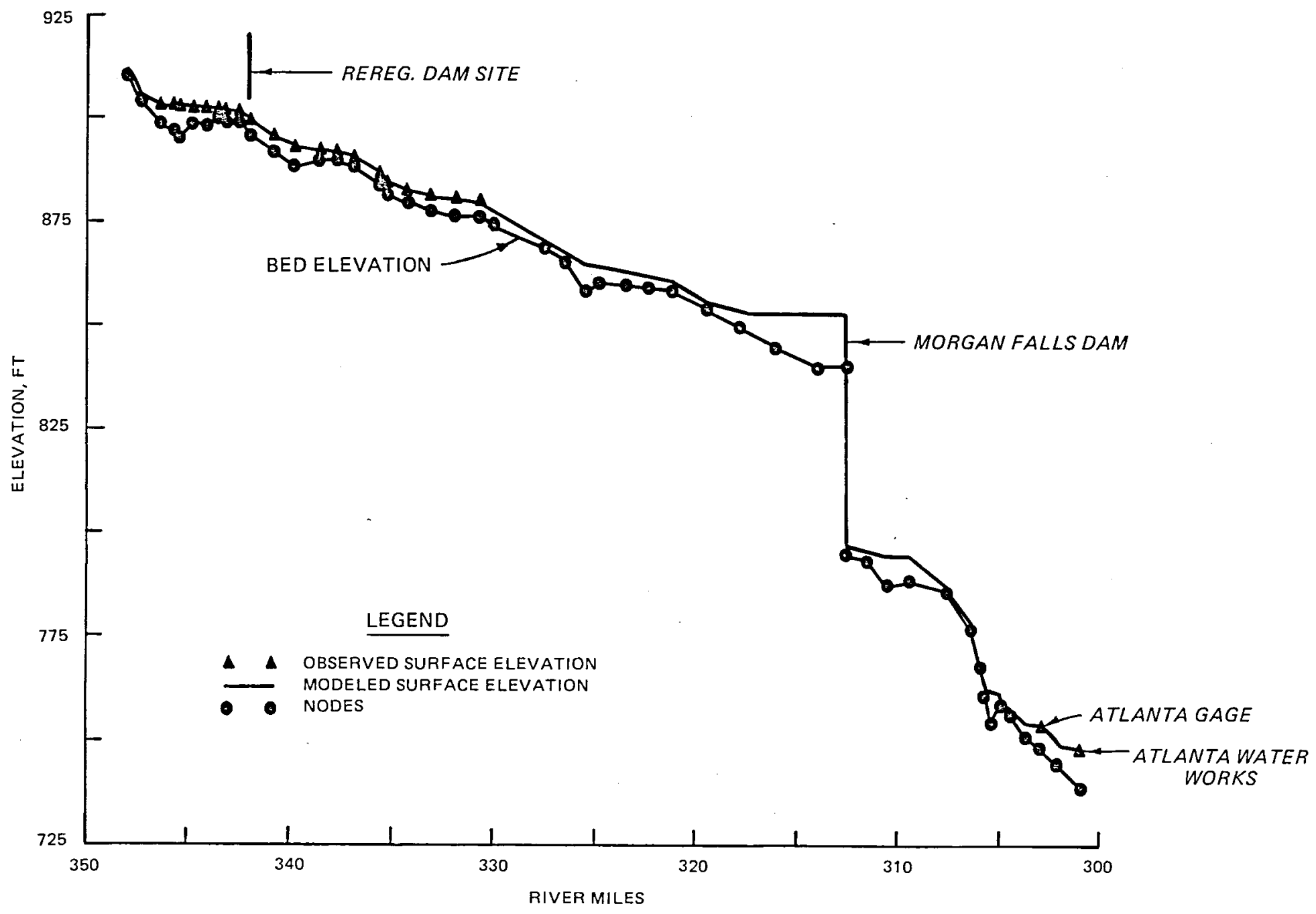

Figure 2. Profile of calibrated and observed stages for steady low-flow event of 17 July 1976 
GA. HWY 20

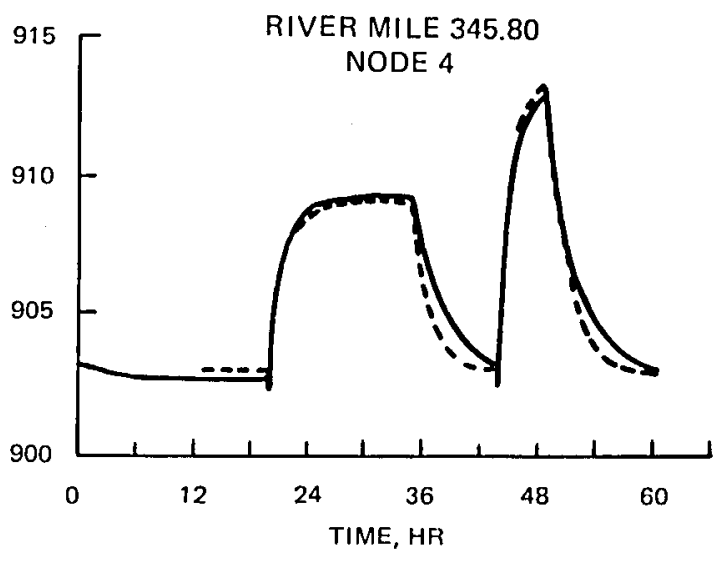

GA. HWY 120

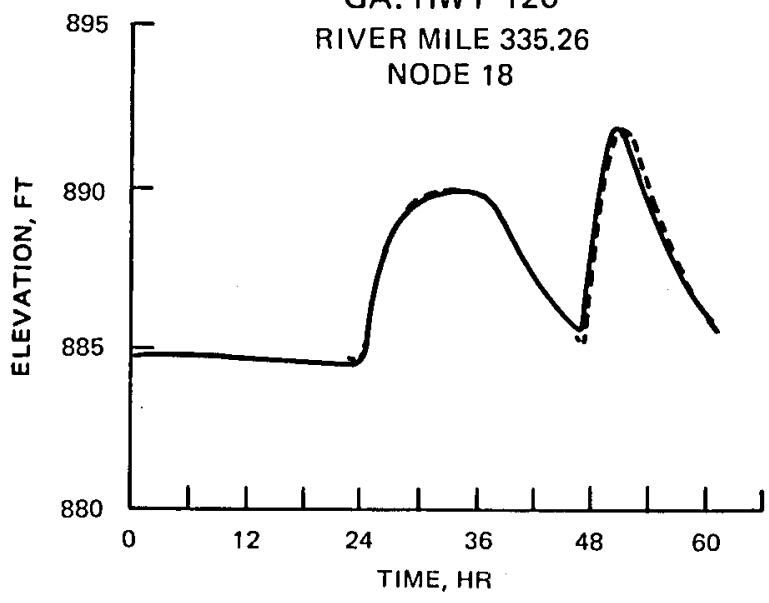

ATLANTA GAGE

RIVER MILE 302.96

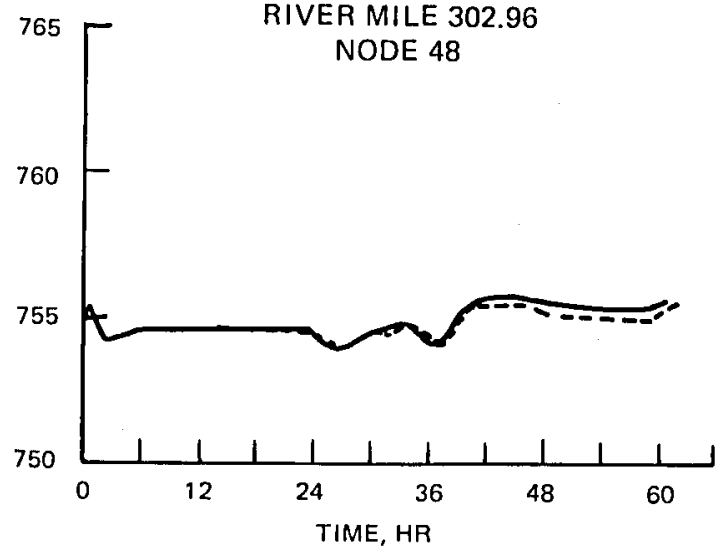

LITTLES FERRY BRIDGE

RIVER MILE 339.86

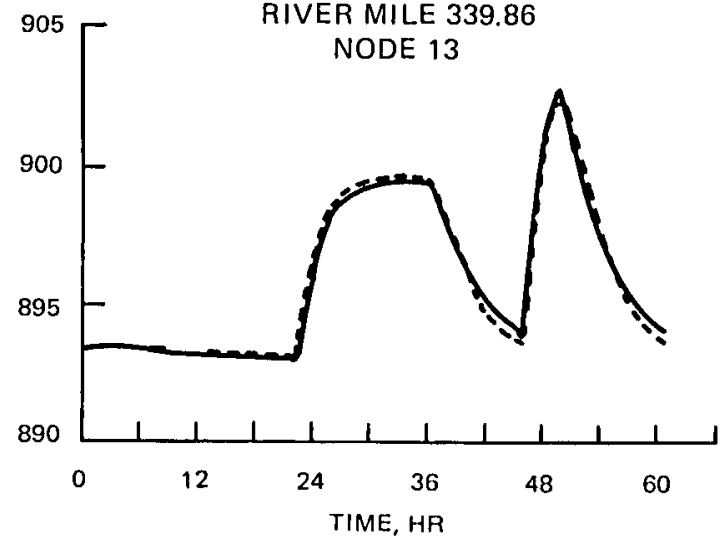

GA. HWY 141

RIVER MILE 330.76 NODE 22

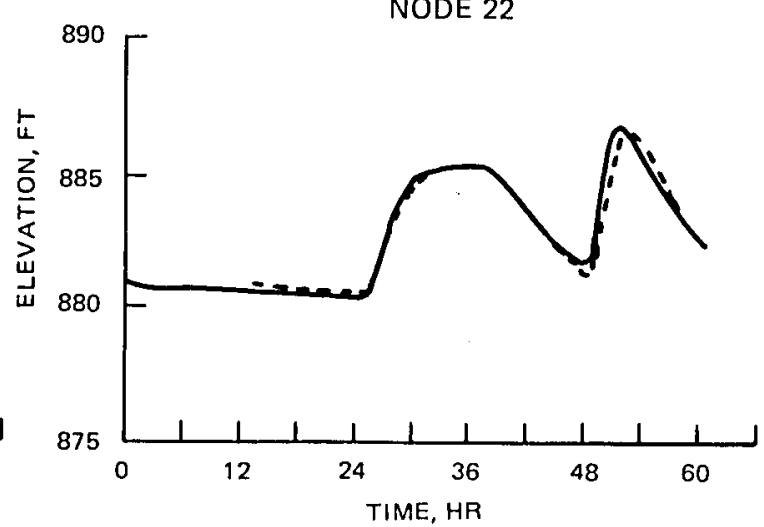

Figure 3. Calibrated and observed stage histories for unsteady flow events of 21-23 March 1976 


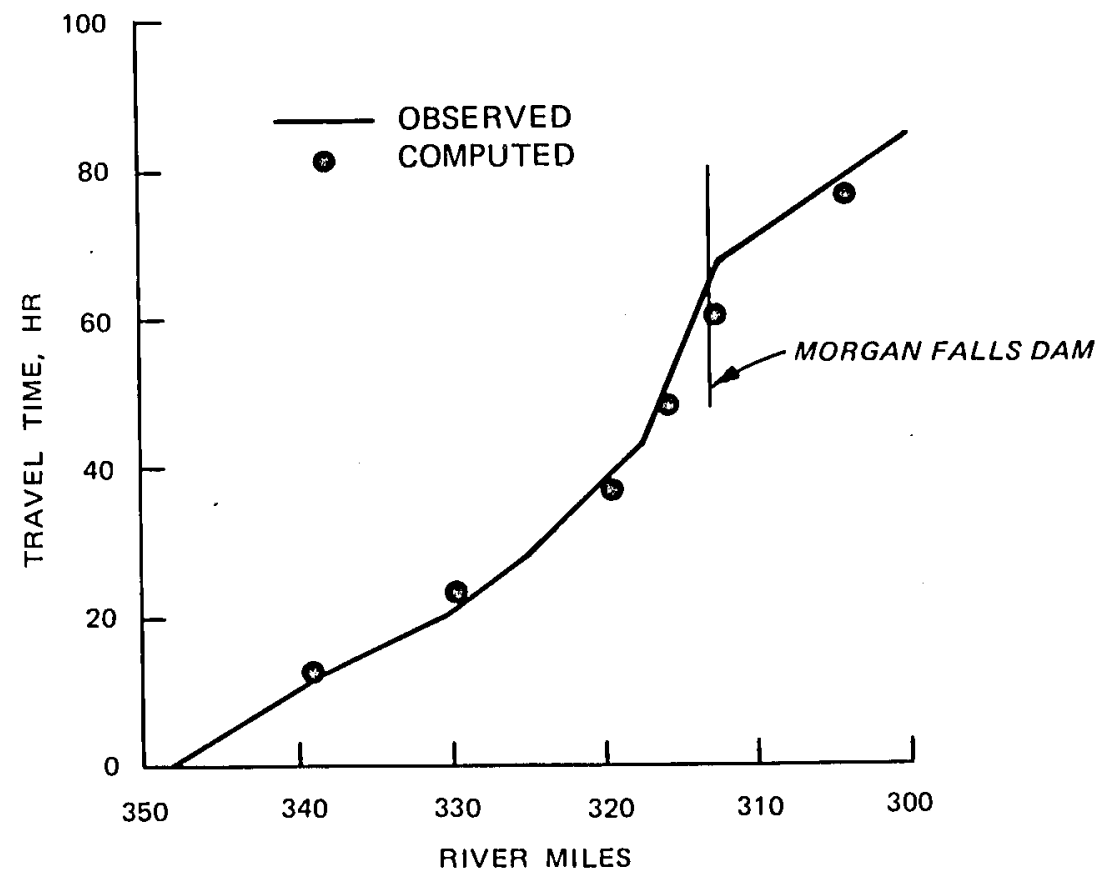

Figure 4. Computed and observed travel times of the peak dye concentration for steady lowflow event 
LITTLES FERRY BRIDGE

RIVER MILE 339.86

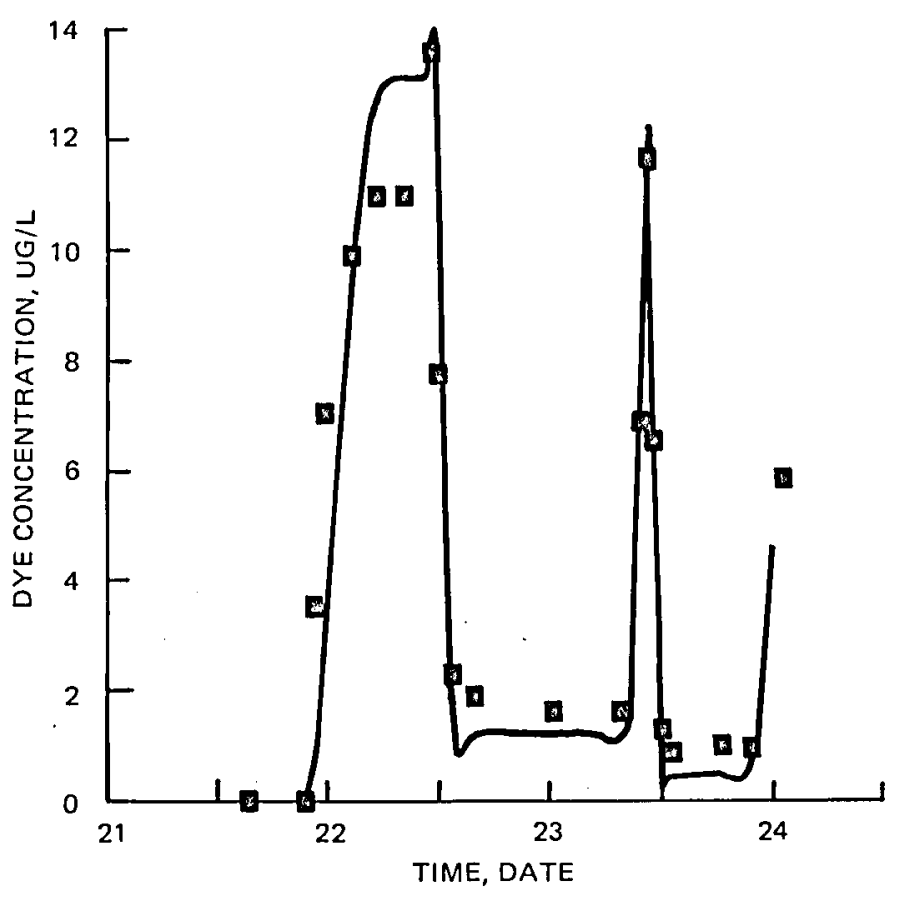

GA. HWY 141

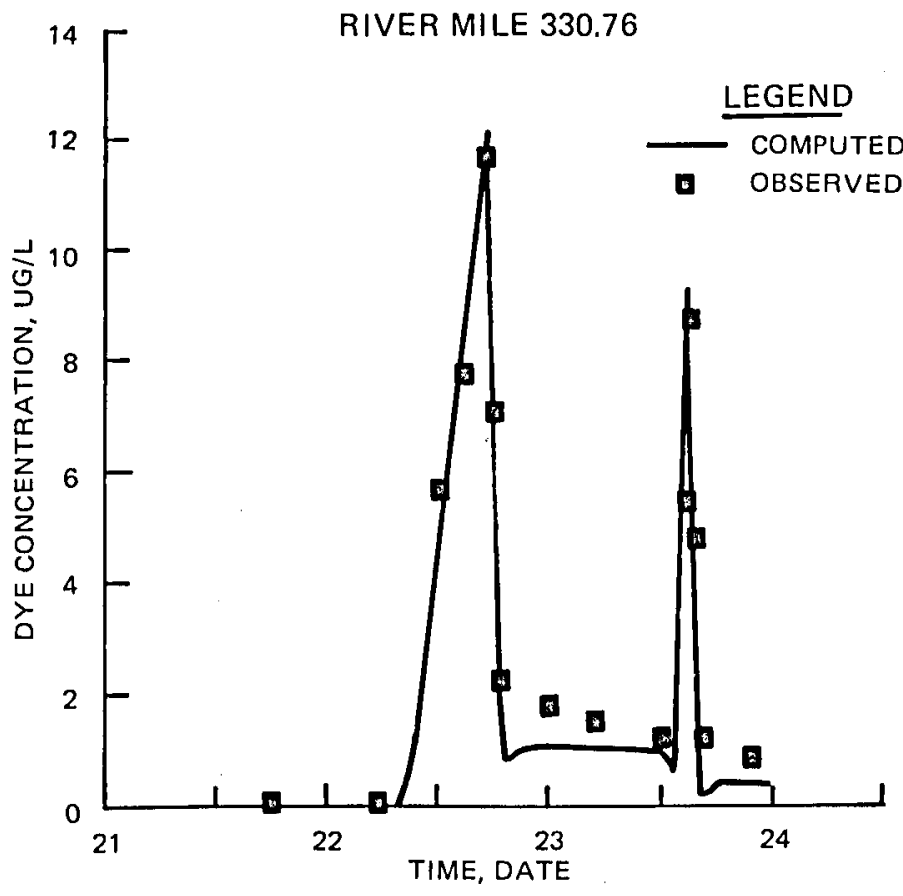

Figure 5. Computed and observed dye concentration histories for unsteady

flow event of 21-23 March 1976 

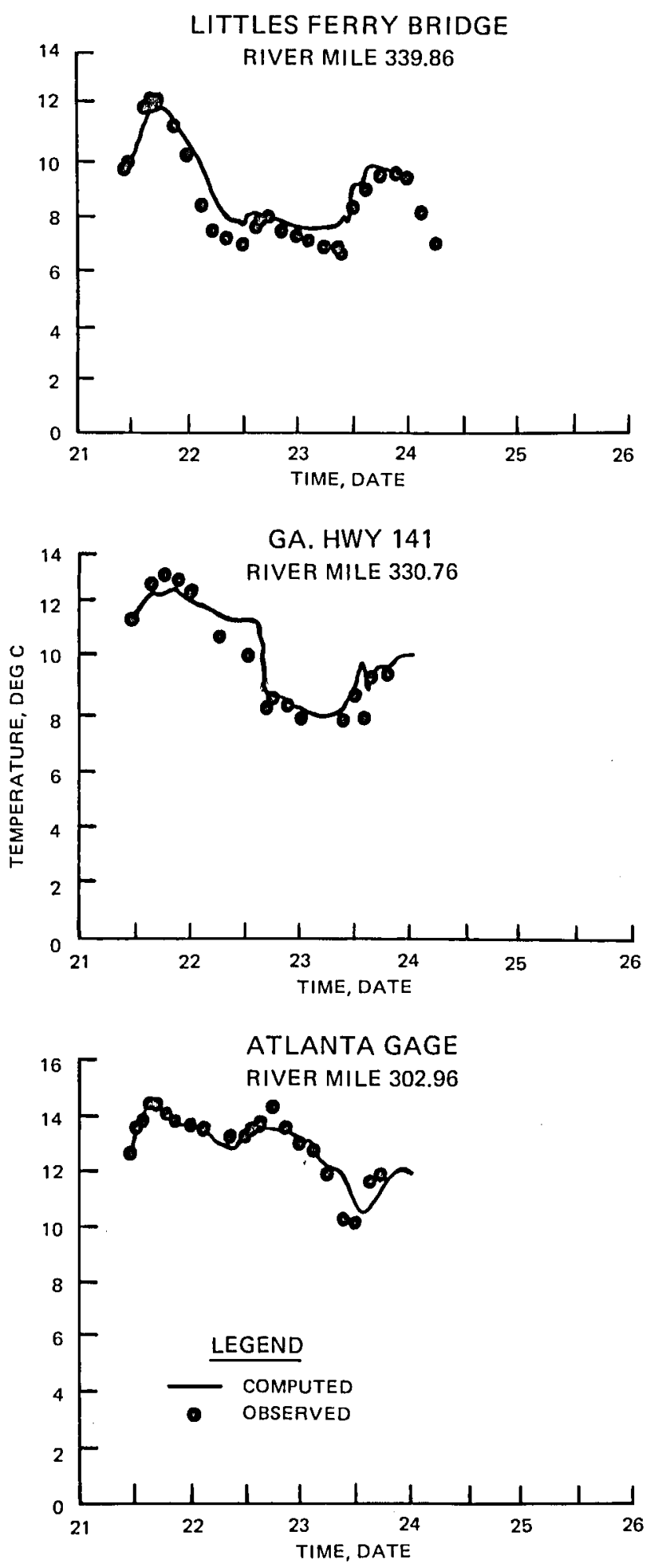

Figure 6. Computed and observed stream temperature histories for unsteady flow event of 21-23 March 1976 


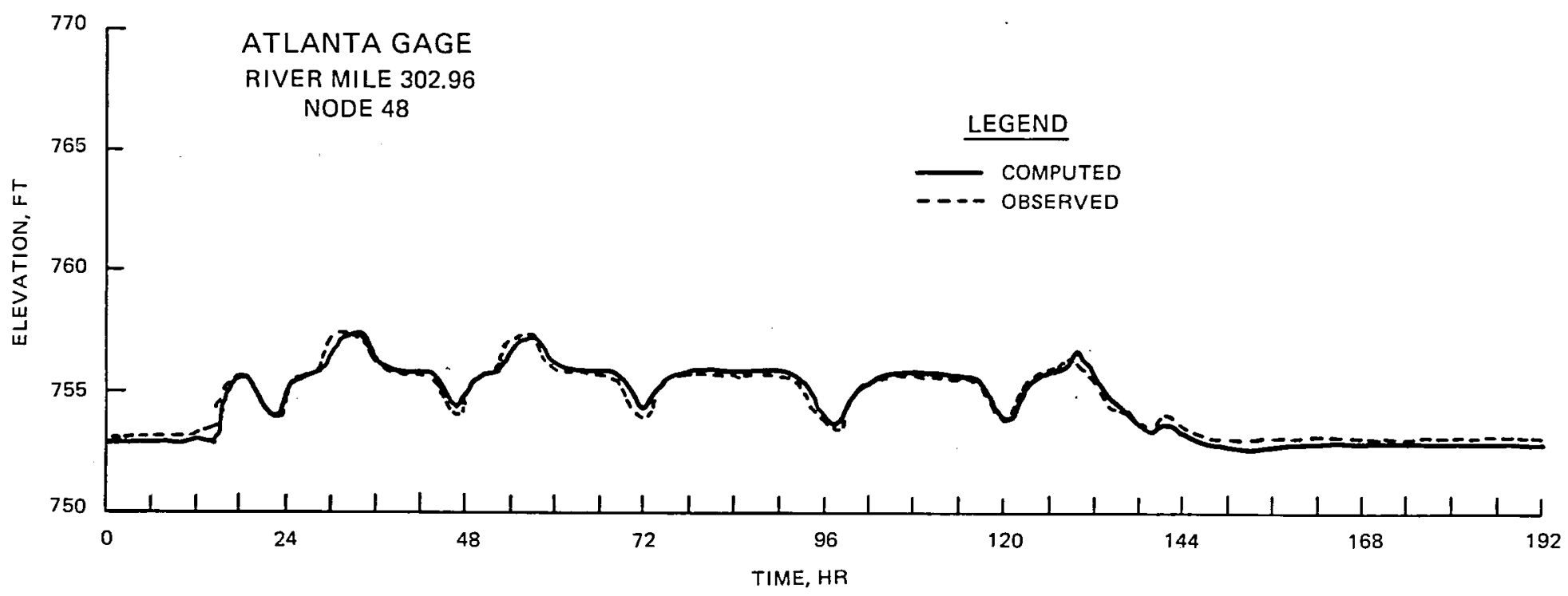

Figure 7. Computed and observed stage history for model confirmation, 12-19 July 1976 


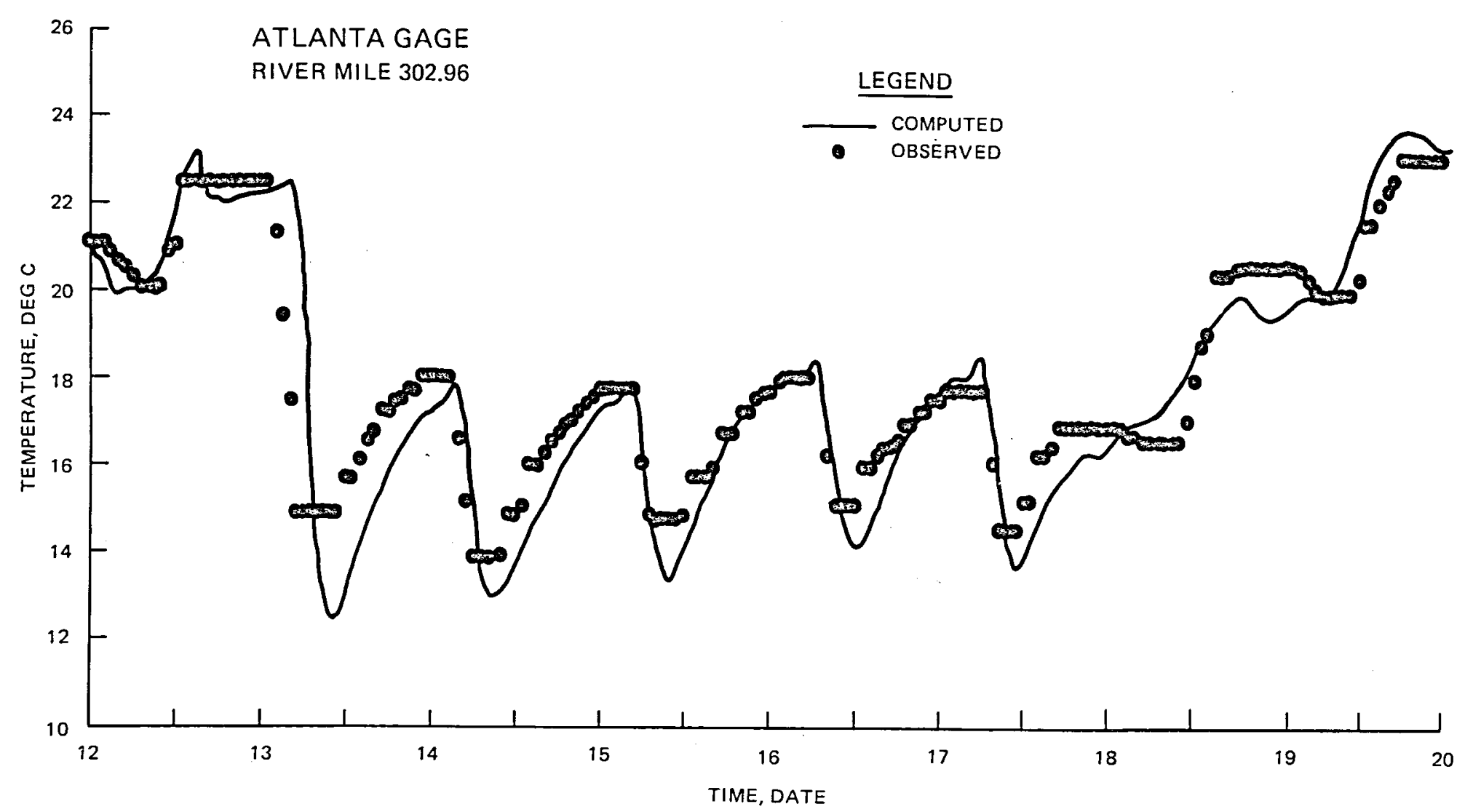

Figure 8. Computed and observed temperature history for model confirmation, 12-19 July 1976 

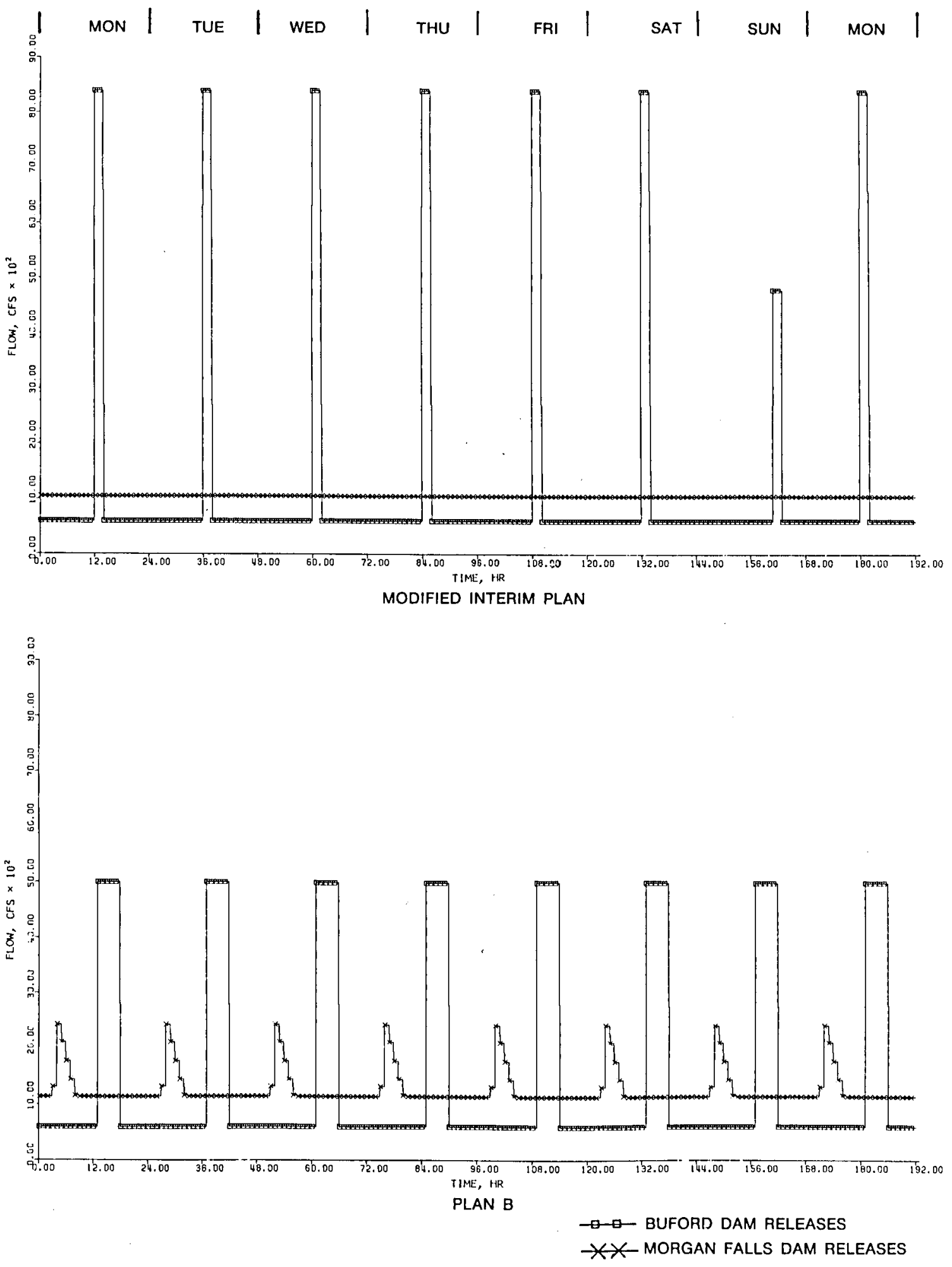

SYSTEM OPERATIONS WITHOUT REREGULATION DAM

Figure 9. System operations for Modified Interim Plan and Plan B 

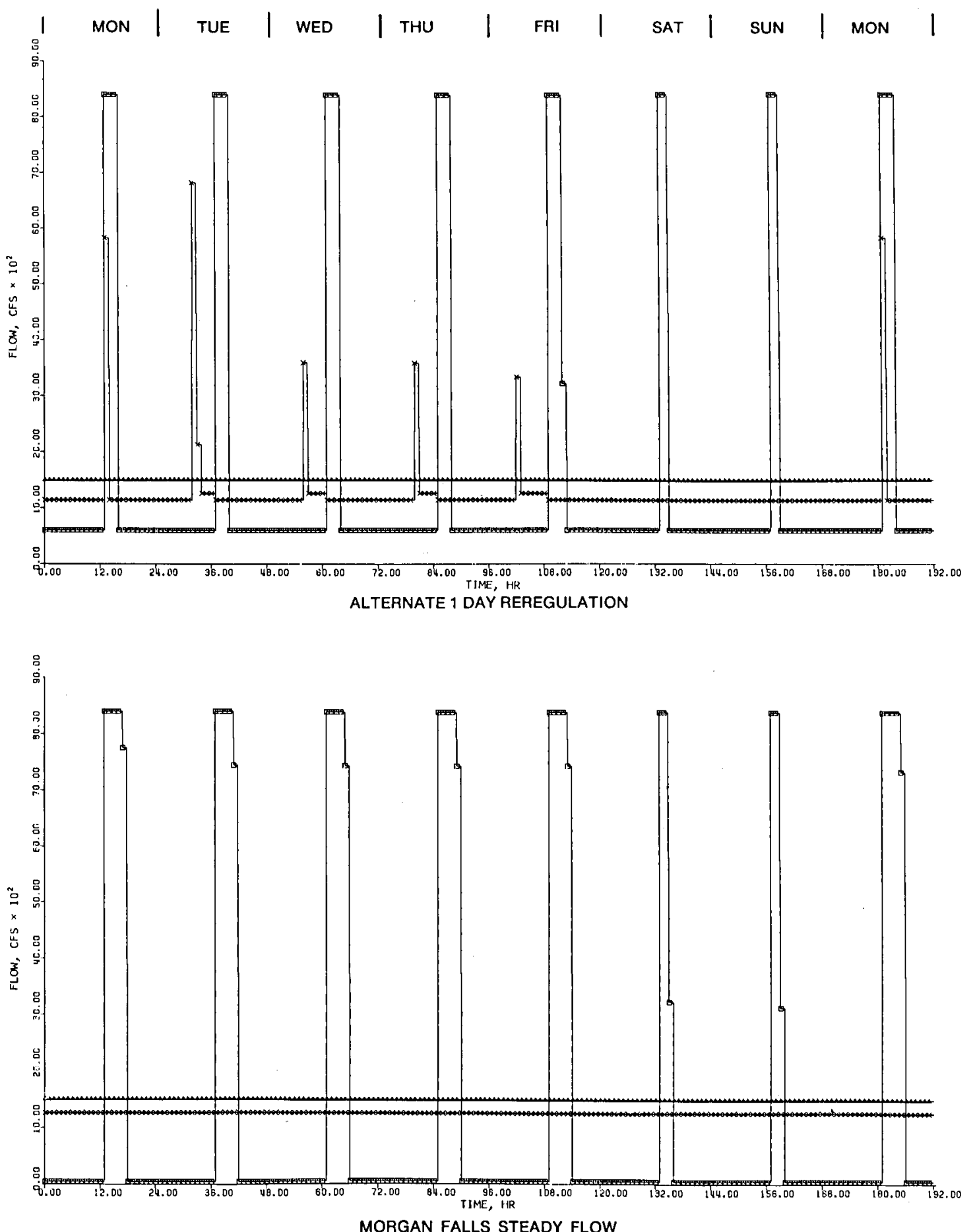

$\longrightarrow$ BUFORD DAM RELEASES

- A Reregulation daM Releases

× MORgan falls daM Releases

SYSTEM OPERATIONS WITH REREGULATION DAM

Figure 10. Five different system operations with rereg dam present (Sheet 1 of 3 ) 

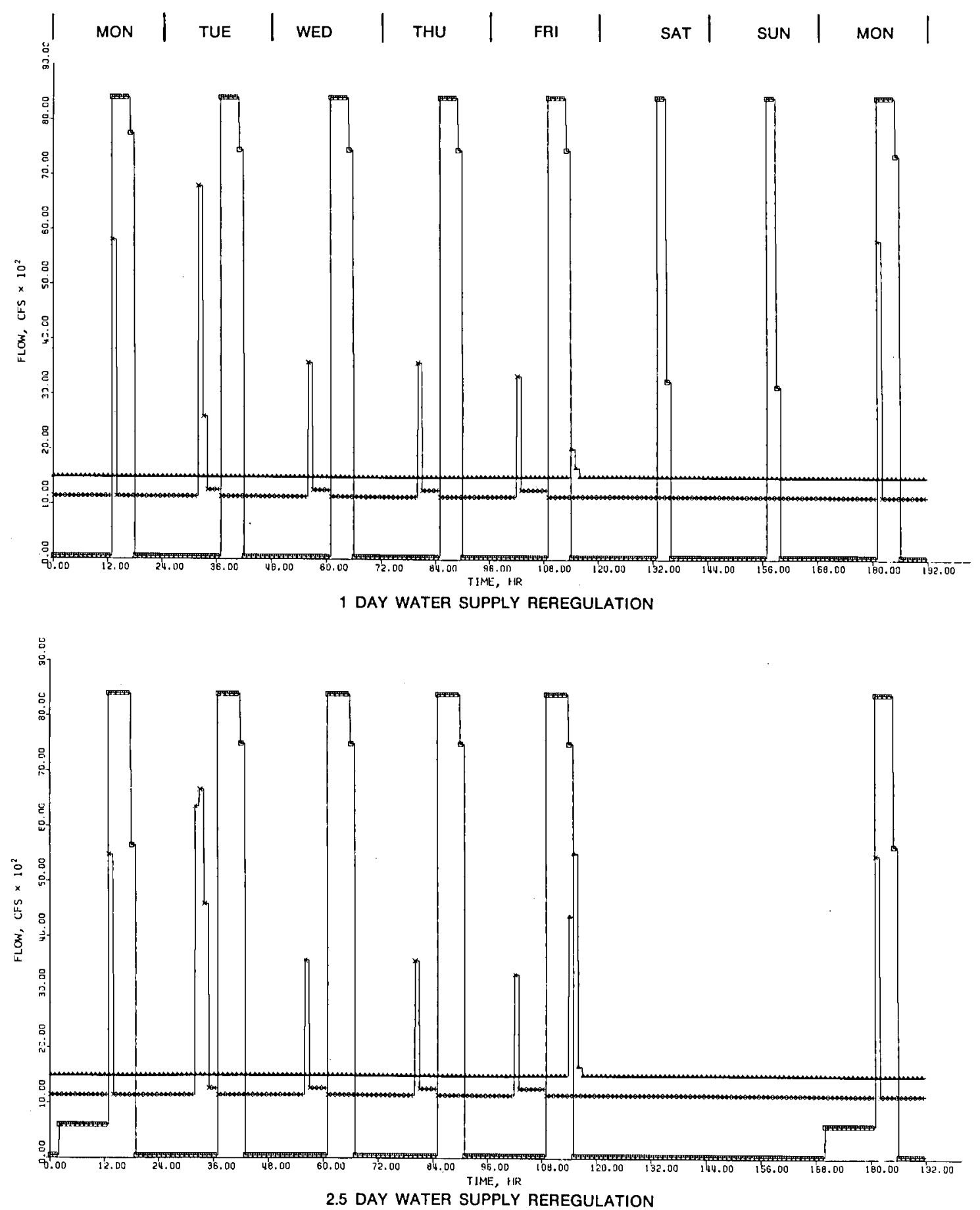

- 0 - BUFORD DAM RELEASES

- 0 - REREgULATION DAM RELEASES

$* x$ MORGan falls daM RELEASES

SYSTEM OPERATIONS WITH REREGULATION DAM

Figure 10. (Sheet 2 of 3 ) 


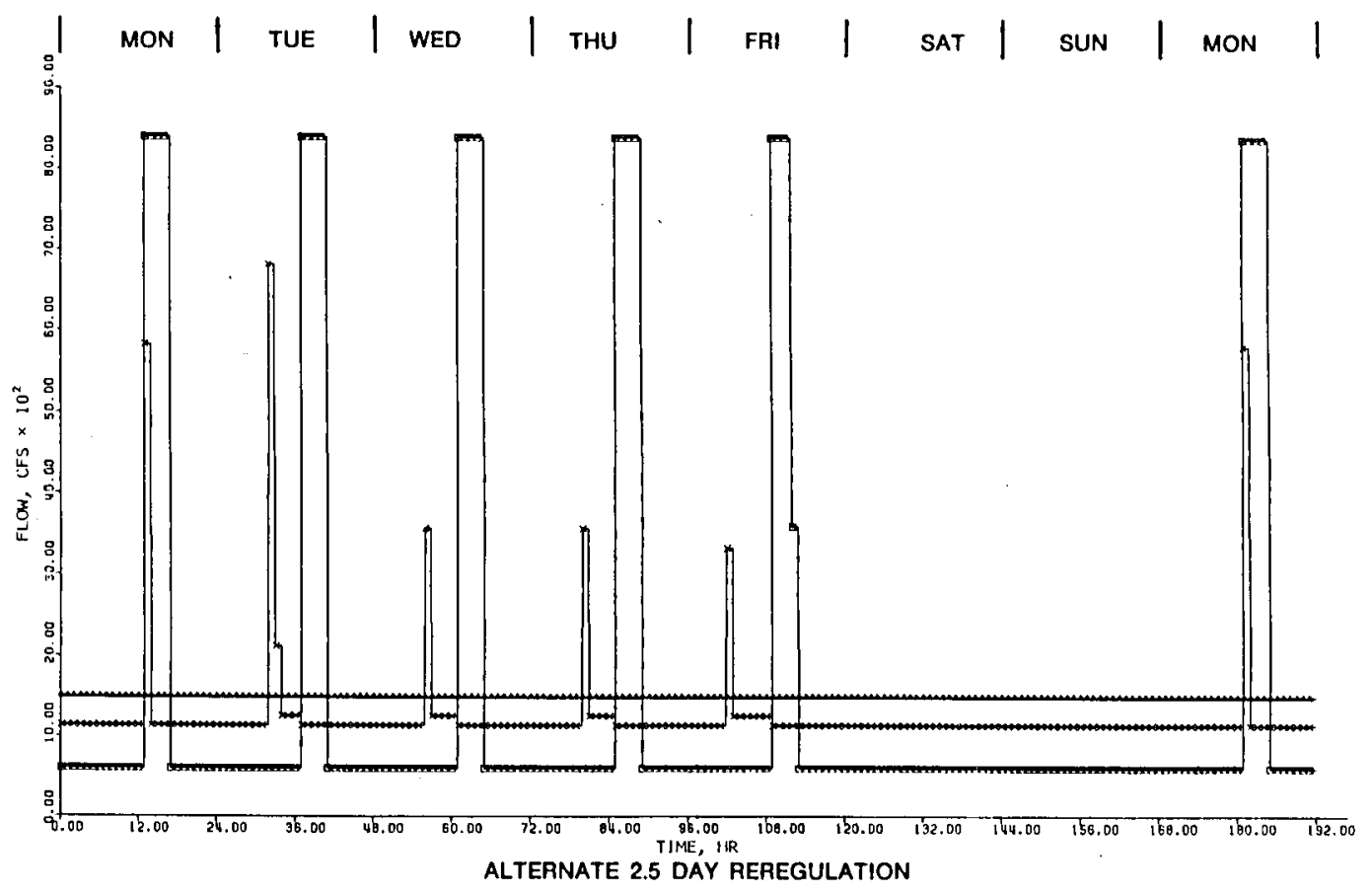

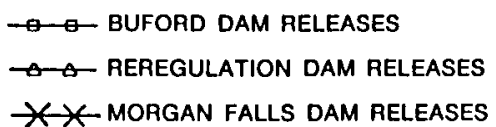

Figure 10. (Sheet 3 of 3 ) 
TROUT HATCHERY
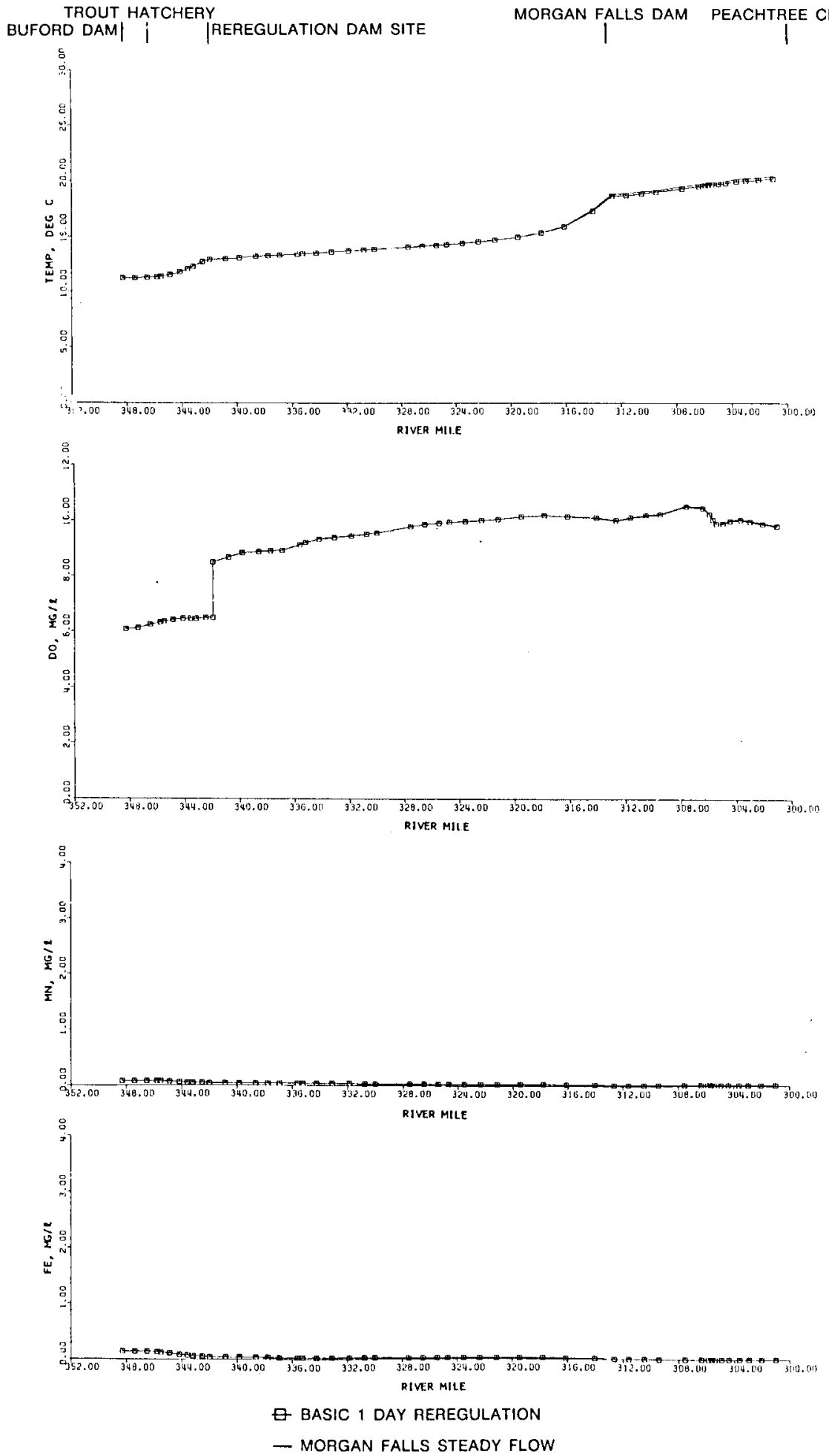

COMPUTED WATER QUALITY AT EACH NODE AVERAGED OVER THE EIGHT DAY SIMULATION, JULY CONDITIONS

Figure 11. Computed water quality comparing effects of basic 1-day rereg operations to those of Morgan Falls Steady Flow option, July conditions 
TROUT HATCHERY
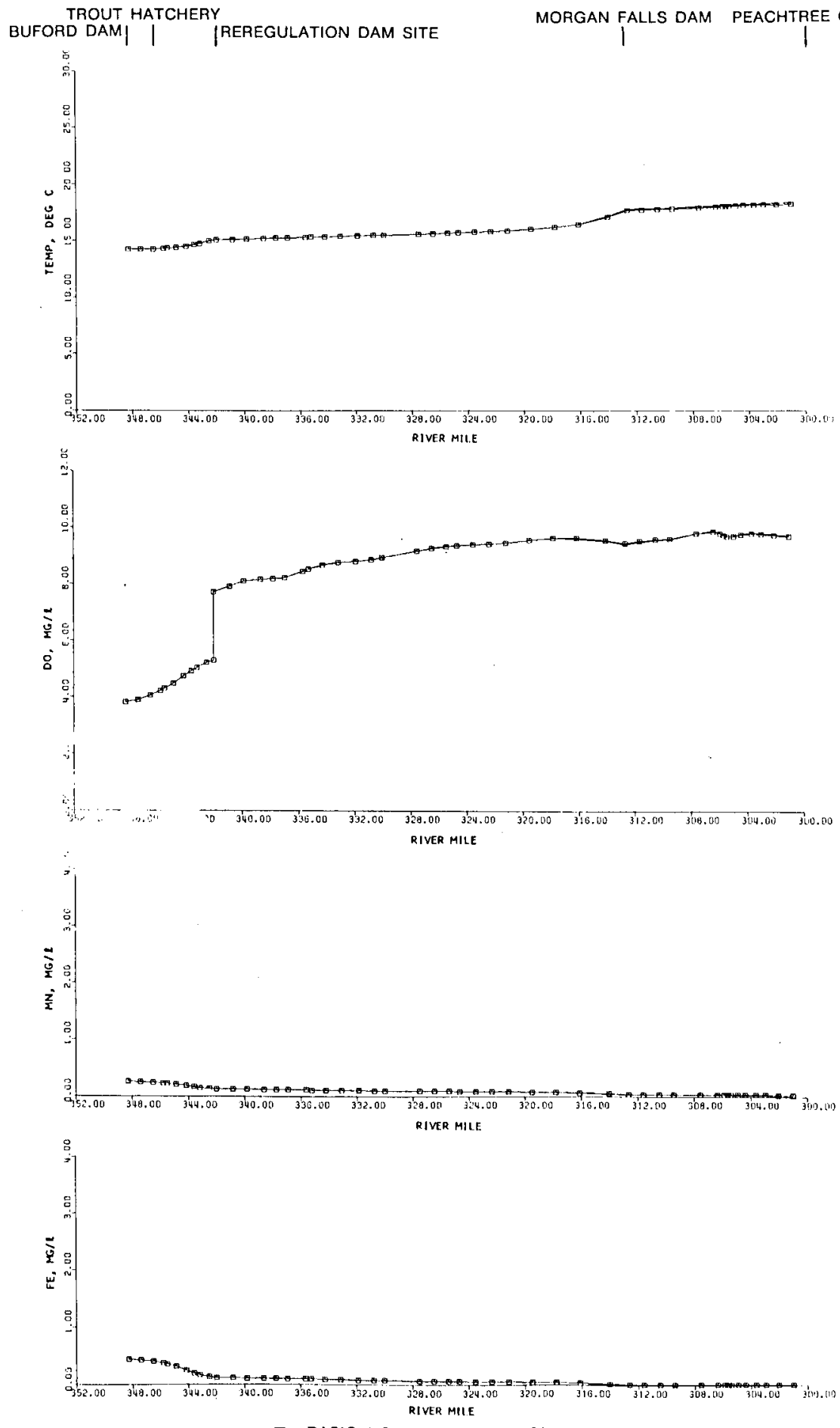

* BASIC 1 DAY REREgULATION

- MORgan faLls STEADY FLOW

COMPUTED WATER QUALITY AT EACH NODE AVERAGED OVER THE EIGHT DAY SIMULATION, OCTOBER CONDITIONS

Figure 12. Computed water quality comparing effects of basic 1-day rereg operations to those of MFSF option, October conditions 


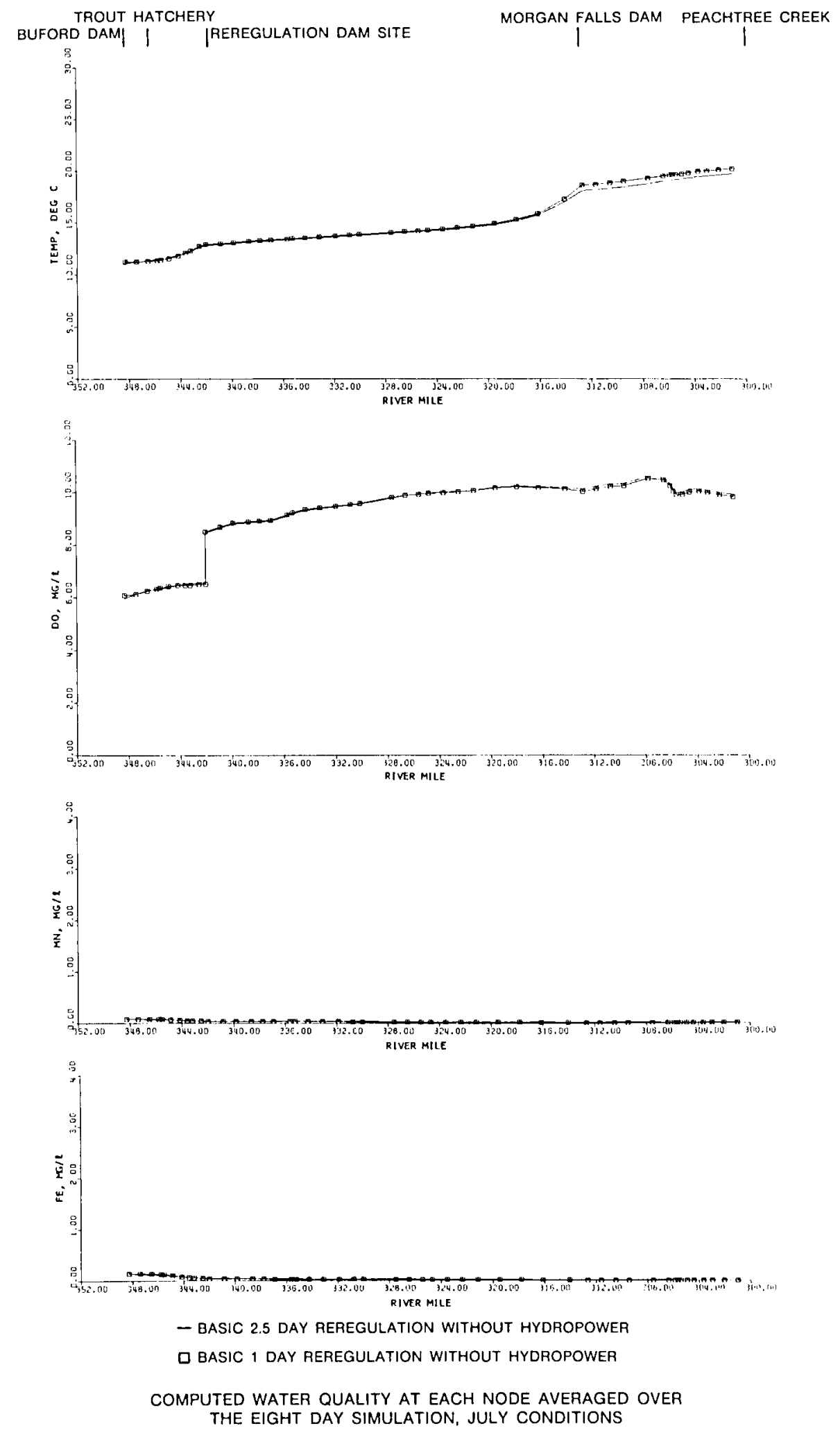

Figure 13. Computed water quality comparing effects of 1-day and 2.5-day rereg dam operations without hydropower, July conditions 


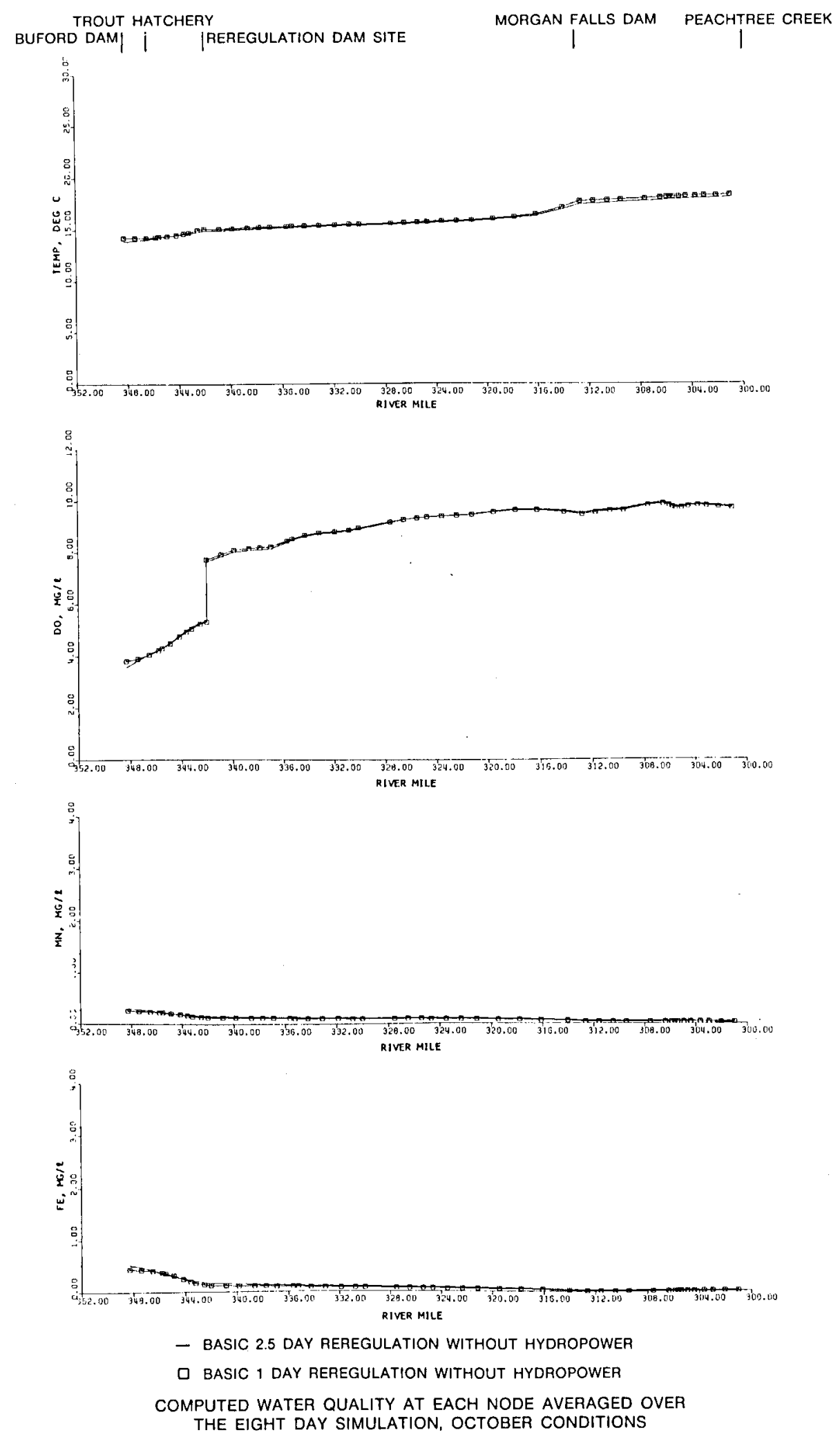

Figure 14. Computed water quality comparing effects of 1-day and 2.5-day rereg dam operations without hydropower, October conditions 

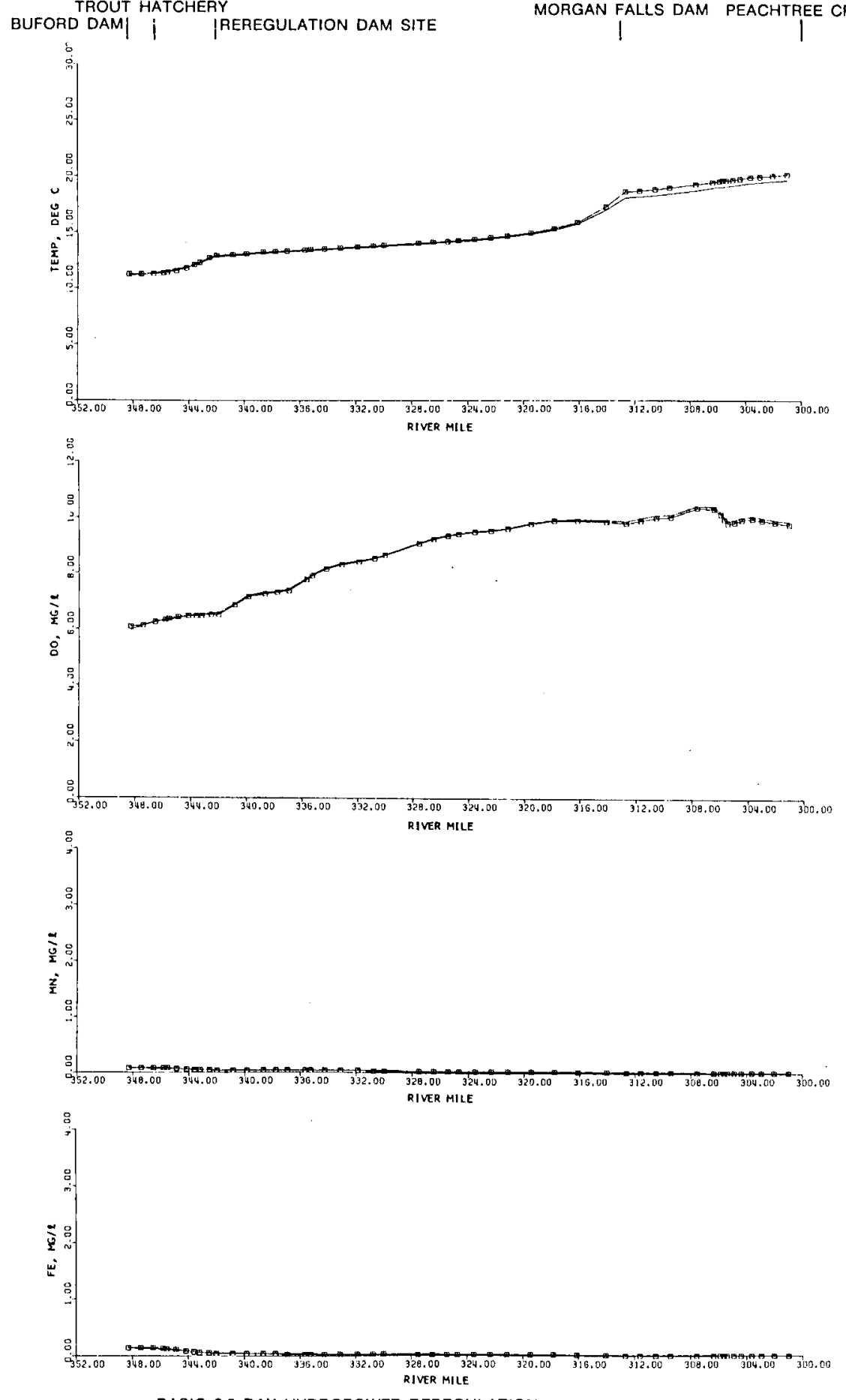

- BASIC 2.5 DAY HYDROPOWER REREGULATION

$\square 1$ DAY REREGULATION WITH HYDROPOWER

COMPUTED WATER QUALITY AT EACH NODE AVERAGED OVER THE EIGHT DAY SIMULATION, JULY CONDITIONS

Figure 15. Computed water quality comparing effects of 1-day and 2.5-day rereg dam operations with hydropower, July conditions 

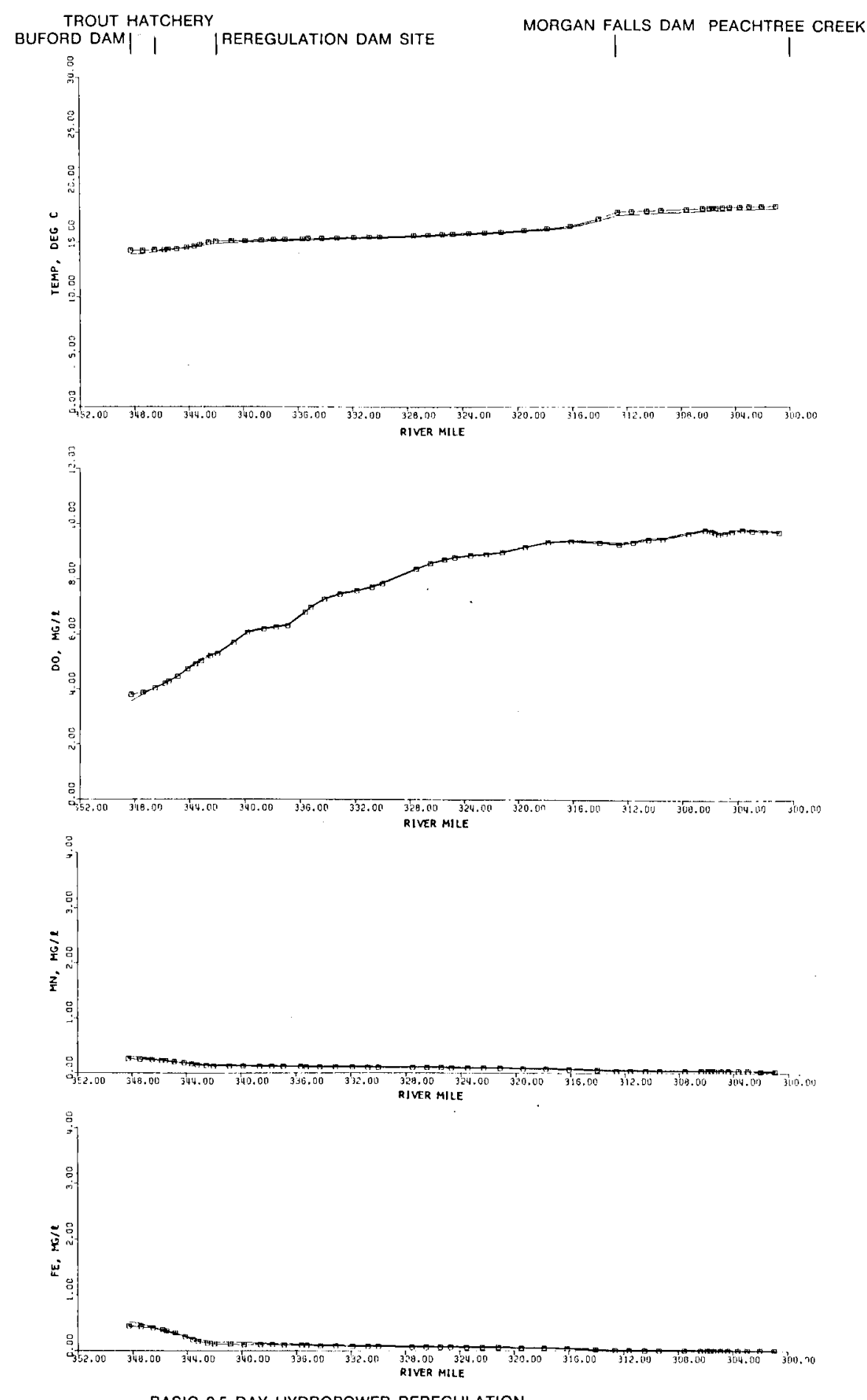

- BASIC 2.5 DaY hYDRopower ReREgulation

口 1 DAY REREGULATION WITH HYDROPOWER

COMPUTED WATER QUALITY AT EACH NODE AVERAGED OVER THE EIGHT DAY SIMULATION, OCTOBER CONDITIONS

Figure 16. Computed water quality comparing effects of 1-day and 2.5-day rereg dam operations with hydropower, October conditions 

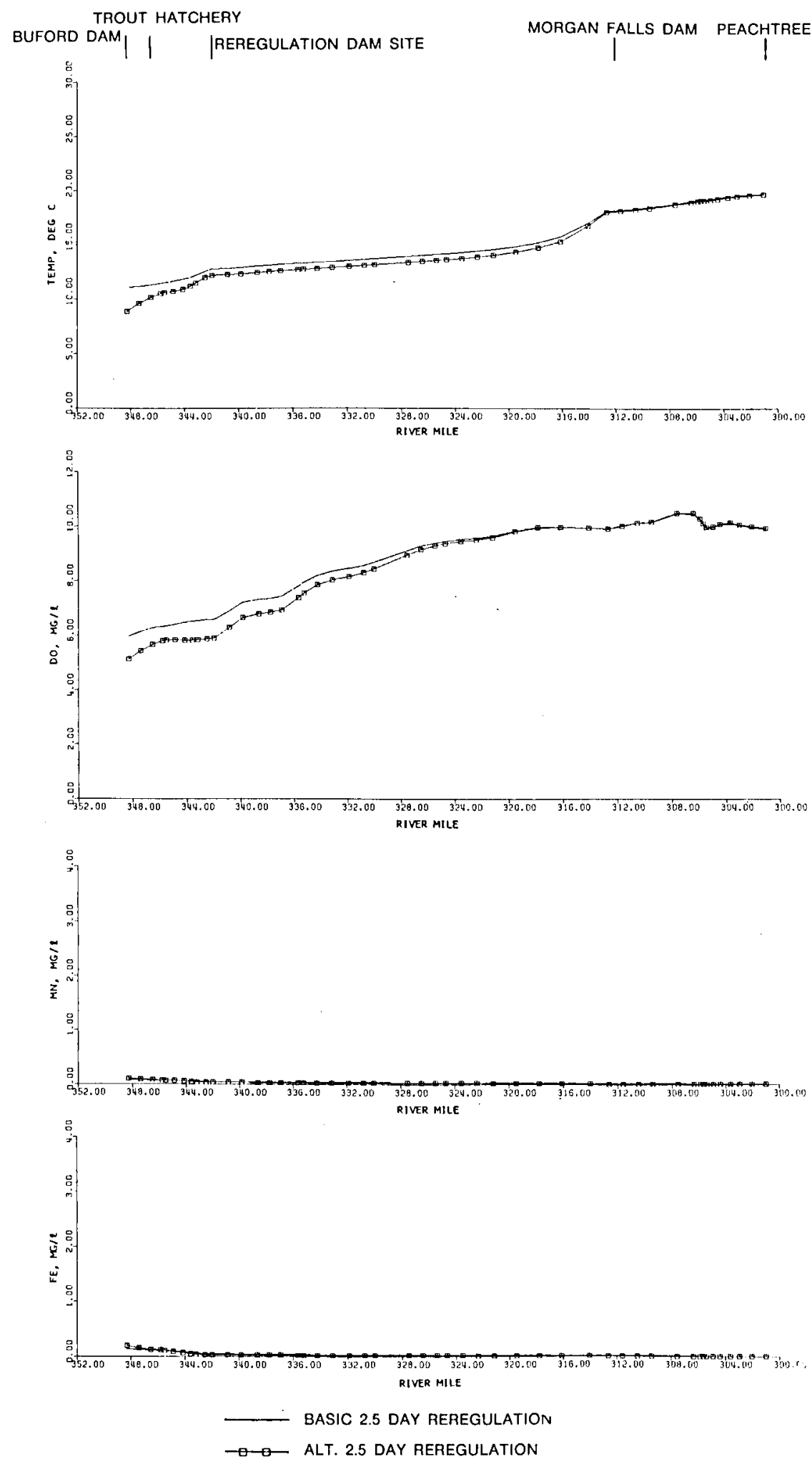

Figure 17. Computed water quality comparing effects of basic (0-cfs minimum flow) to alternate (600-cfs minimum flow) 2.5-day rereg dam operations averaged over 8-day simulation, July conditions 

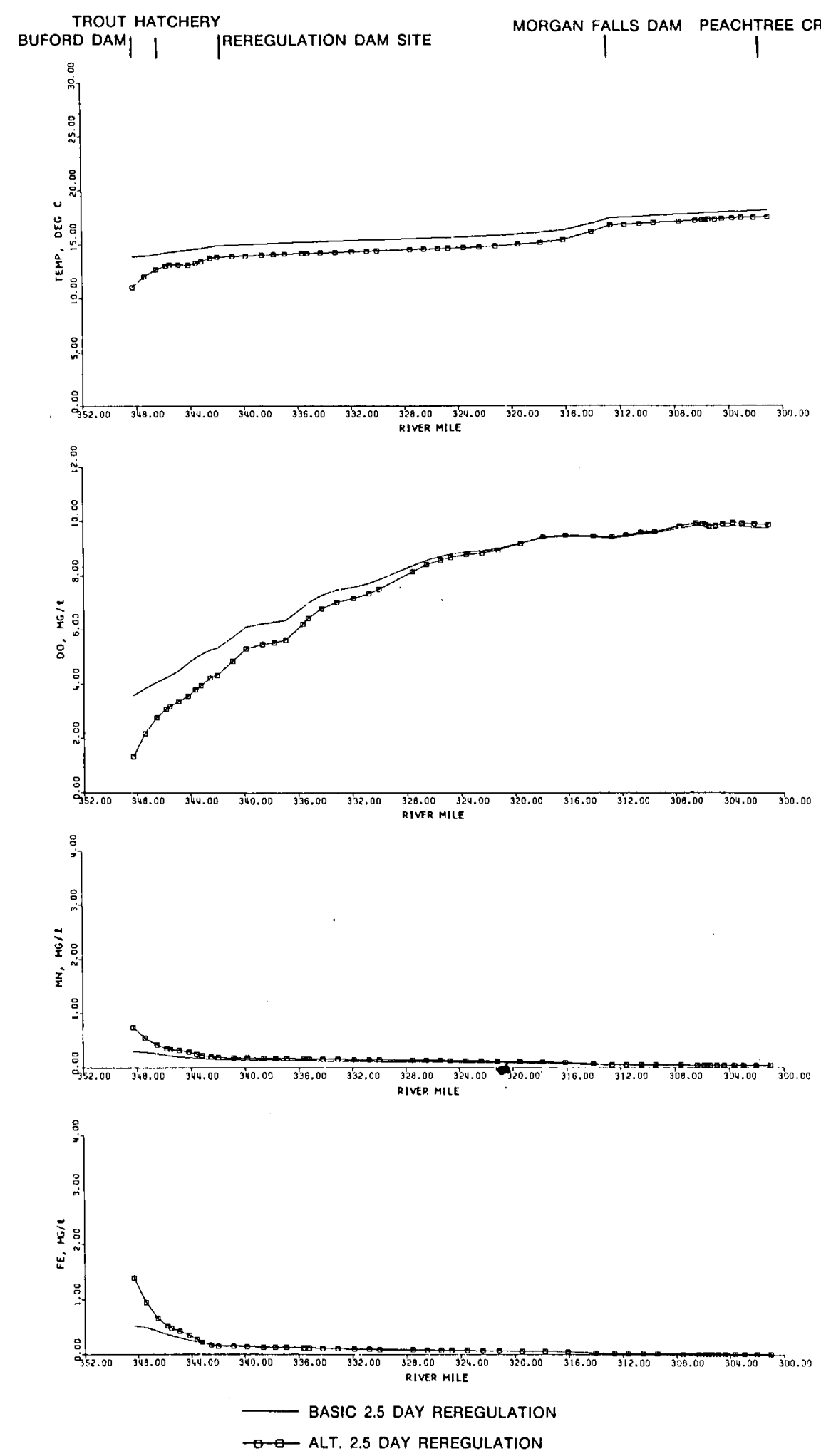

Figure 18. Computed water quality comparing effects of basic (0-cfs minimum flow) to alternate (600-cfs minimum flow) 2.5-day rereg dam operations, averaged over 8-day simulation, October conditions 

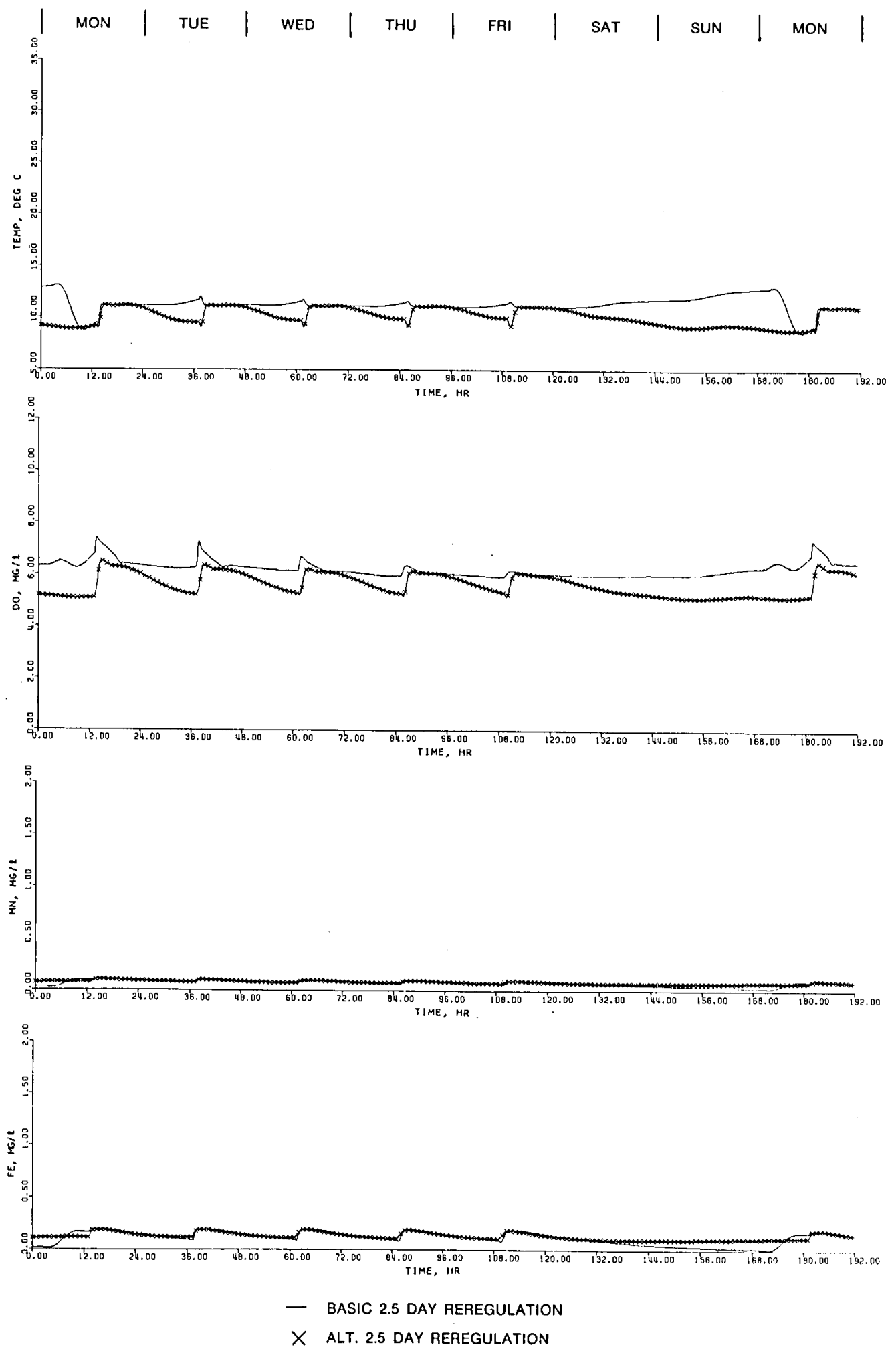

COMPUTED WATER QUALITY AT TROUT HATCHERY, JULY CONDITIONS

Figure 19. Computed water quality at trout hatchery comparing effects of basic ( 0 -cfs minimum flow) to alternate (600-cfs minimum flow) 2.5-day rereg dam operations, July conditions 

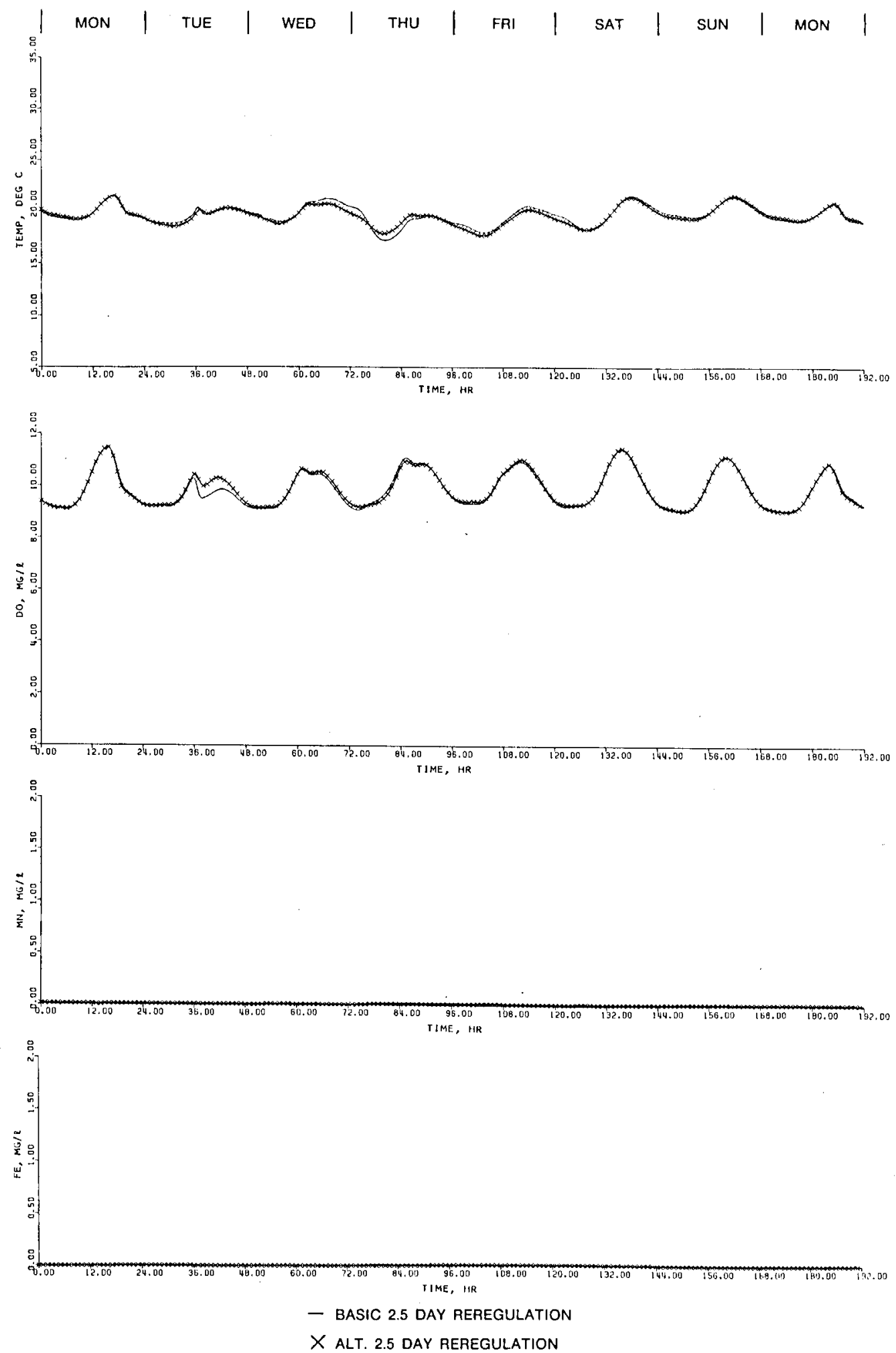

COMPUTED WATER QUALITY AT PEACHTREE CREEK, JULY CONDITIONS

Figure 20. Computed water quality at Peachtree Creek

comparing effects of basic (0-cfs minimum flow) to

alternate (600-cfs minimum flow) 2.5-day rereg dam

operations, July conditions 

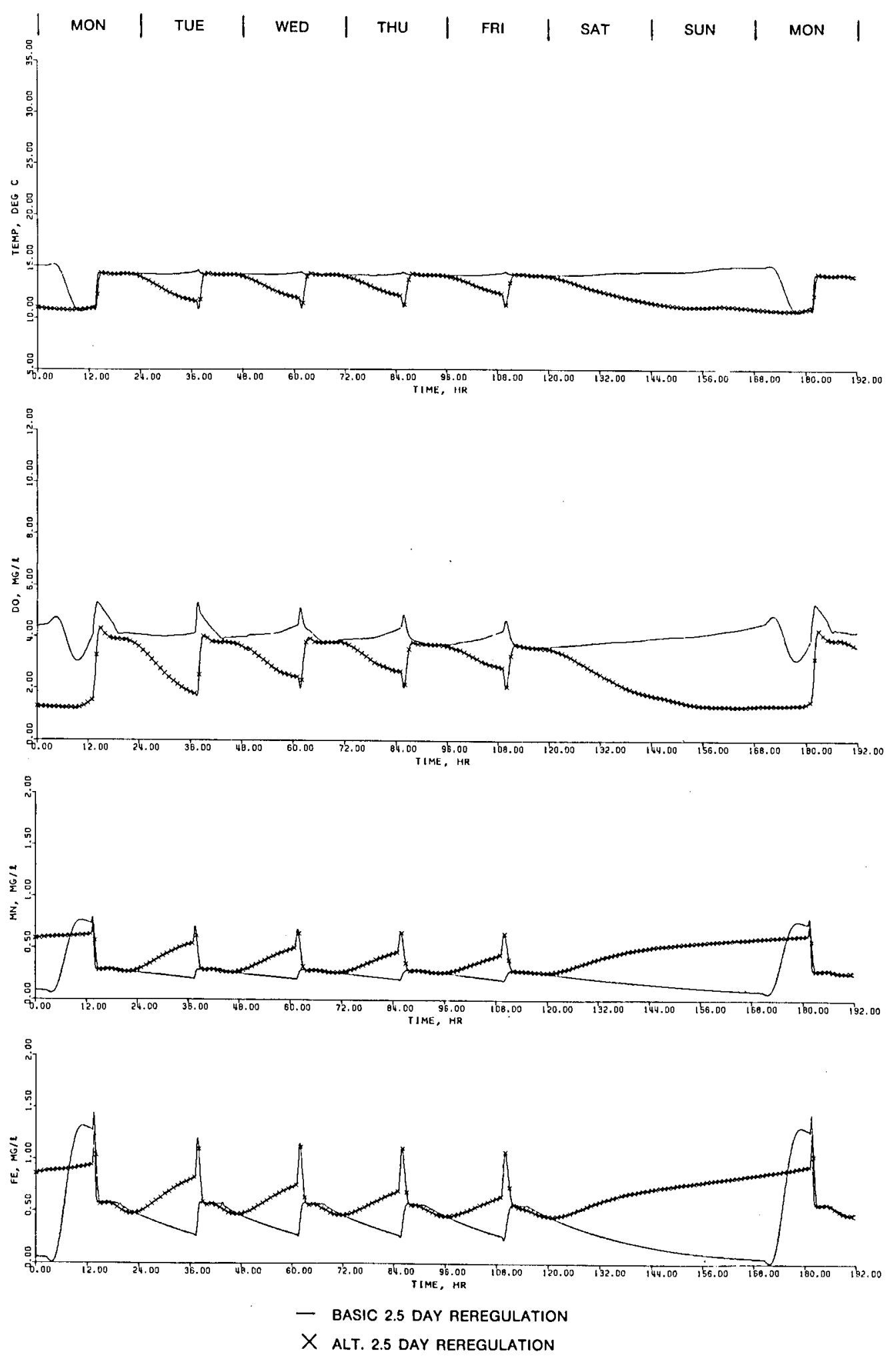

COMPUTED WATER QUALITY AT TROUT HATCHERY, OCTOBER CONDITIONS

Figure 21. Computed water quality at trout hatchery comparing effects of basic (0-cfs minimum flow) to alternate (600-cfs minimum flow) 2.5-day rereg dam operations, October conditions 

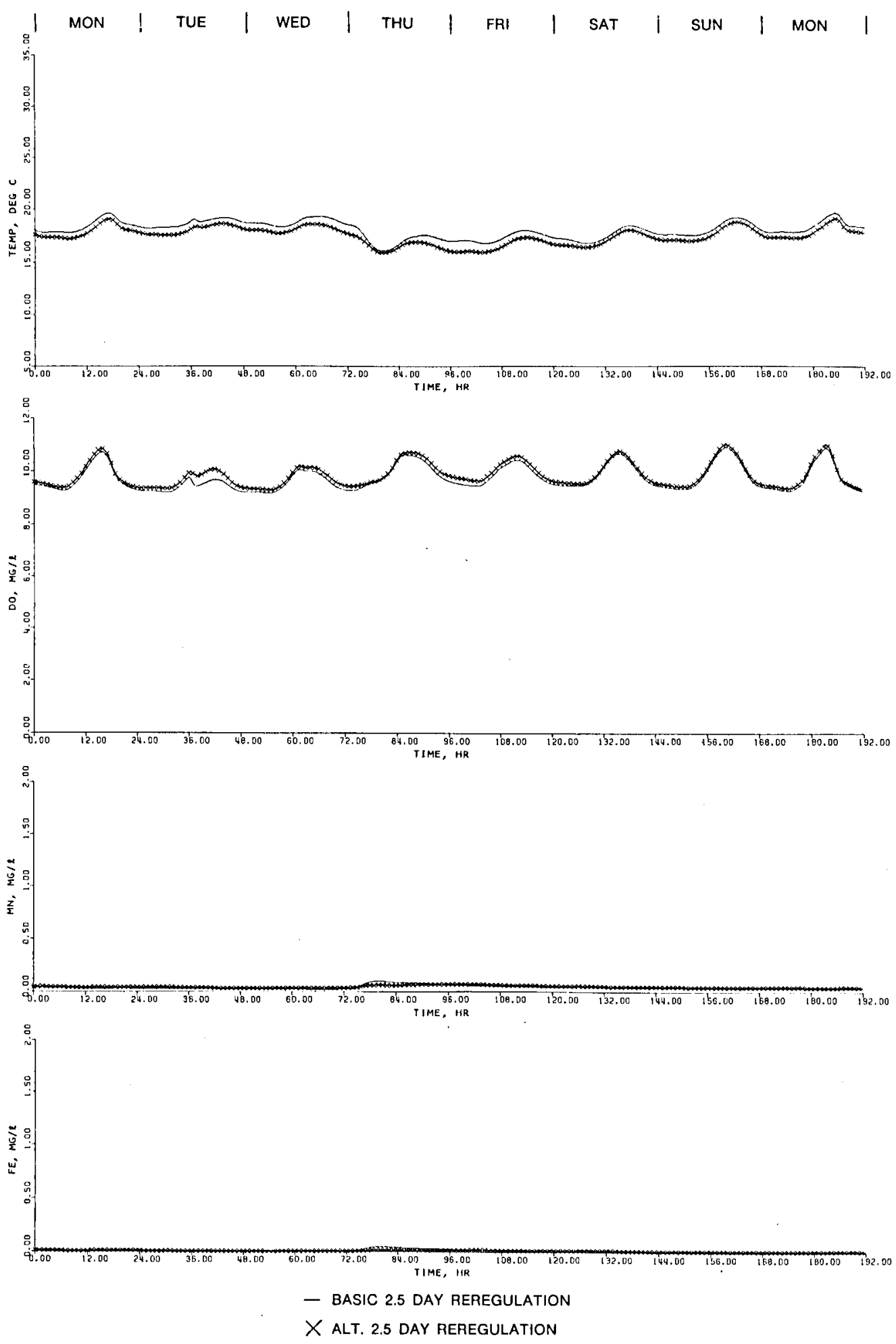

COMPUTED WATER QUALITY AT PEACHTREE CREEK, OCTOBER CONDITIONS

Figure 22. Computed water quality at Peachtree Creek comparing effects of basic (0-cfs minimum flow) to alternate (600-cfs minimum flow) 2.5-day rereg dam operations, October conditions 

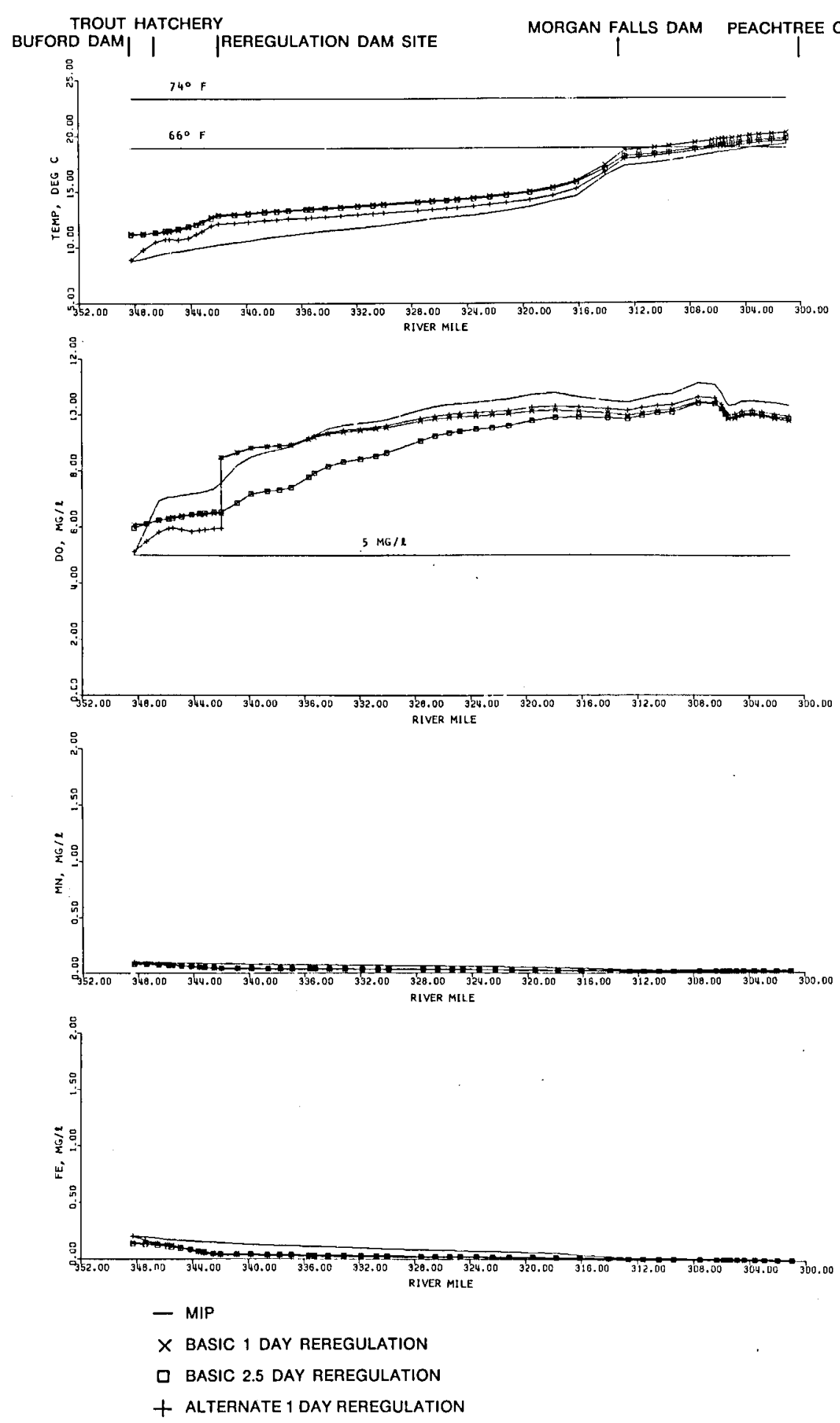

COMPUTED WATER QUALITY AT EACH NODE AVERAGED OVER THE EIGHT DAY SIMULATION, JULY CONDITIONS

Figure 23. Computed water quality comparing effects of Modified Interim Plan with three rereg operation alternatives, averaged over 8-day simulation, July conditions 

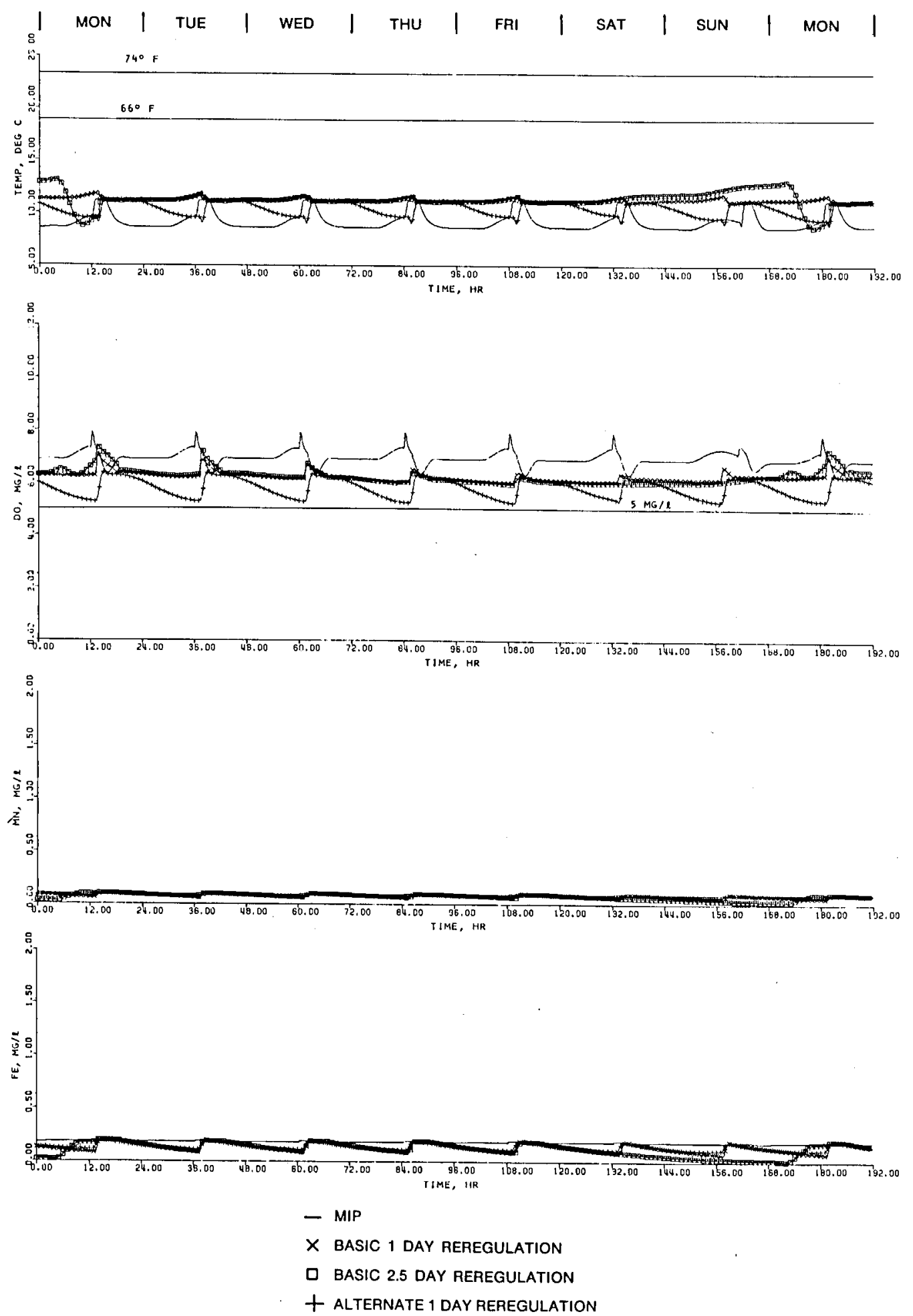

COMPUTED WATER QUALITY AT TROUT HATCHERY, JULY CONDITIONS

Figure 24. Computed water quality at trout hatchery comparing effects of Modified Interim Plan with three rereg operation alternatives, July conditions 

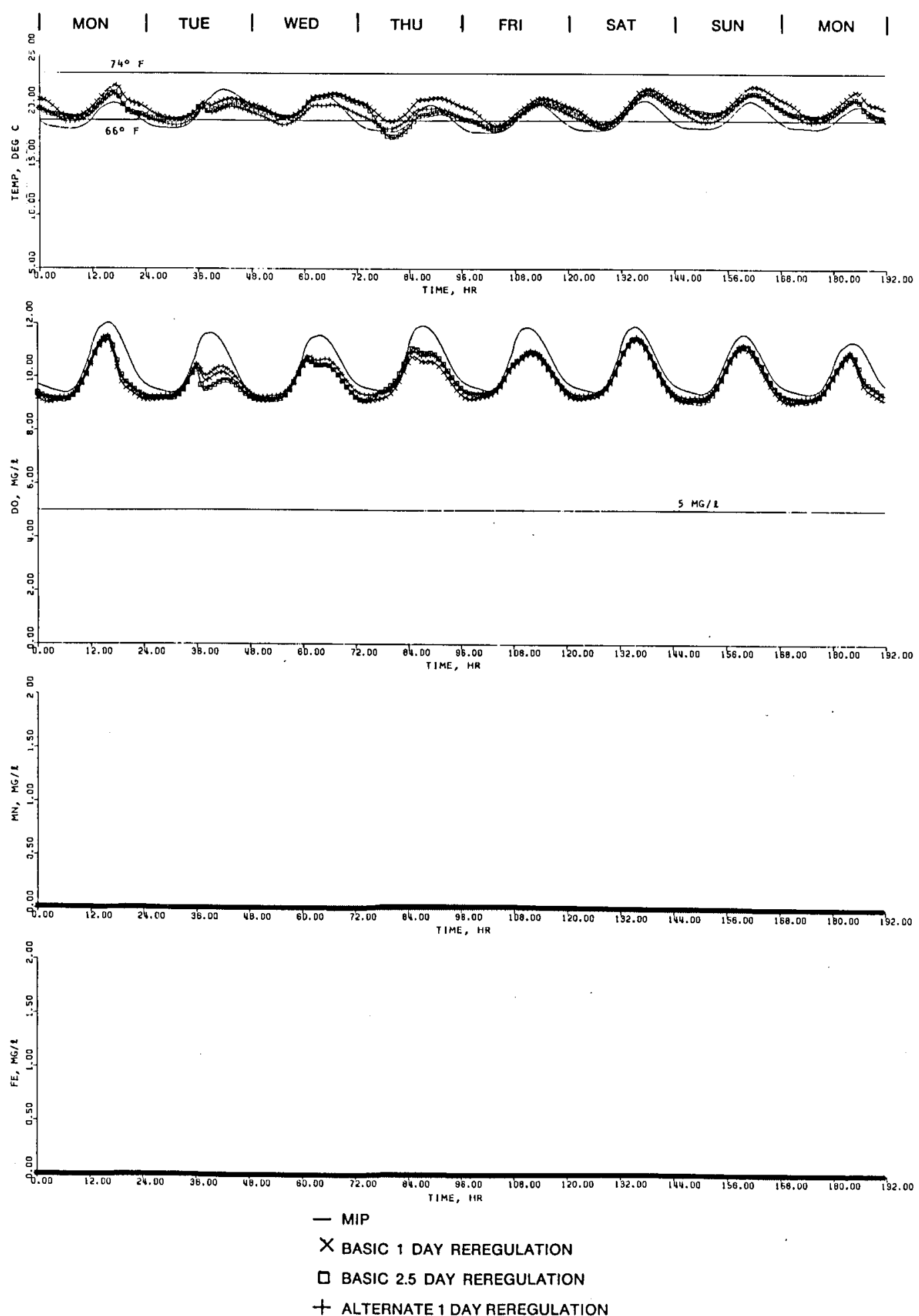

COMPUTED WATER QUALITY AT PEACHTREE CREEK, JULY CONDITIONS

Figure 25. Computed water quality at Peachtree Creek comparing effects of Modified Interim Plan with three rereg operation alternatives, July conditions 

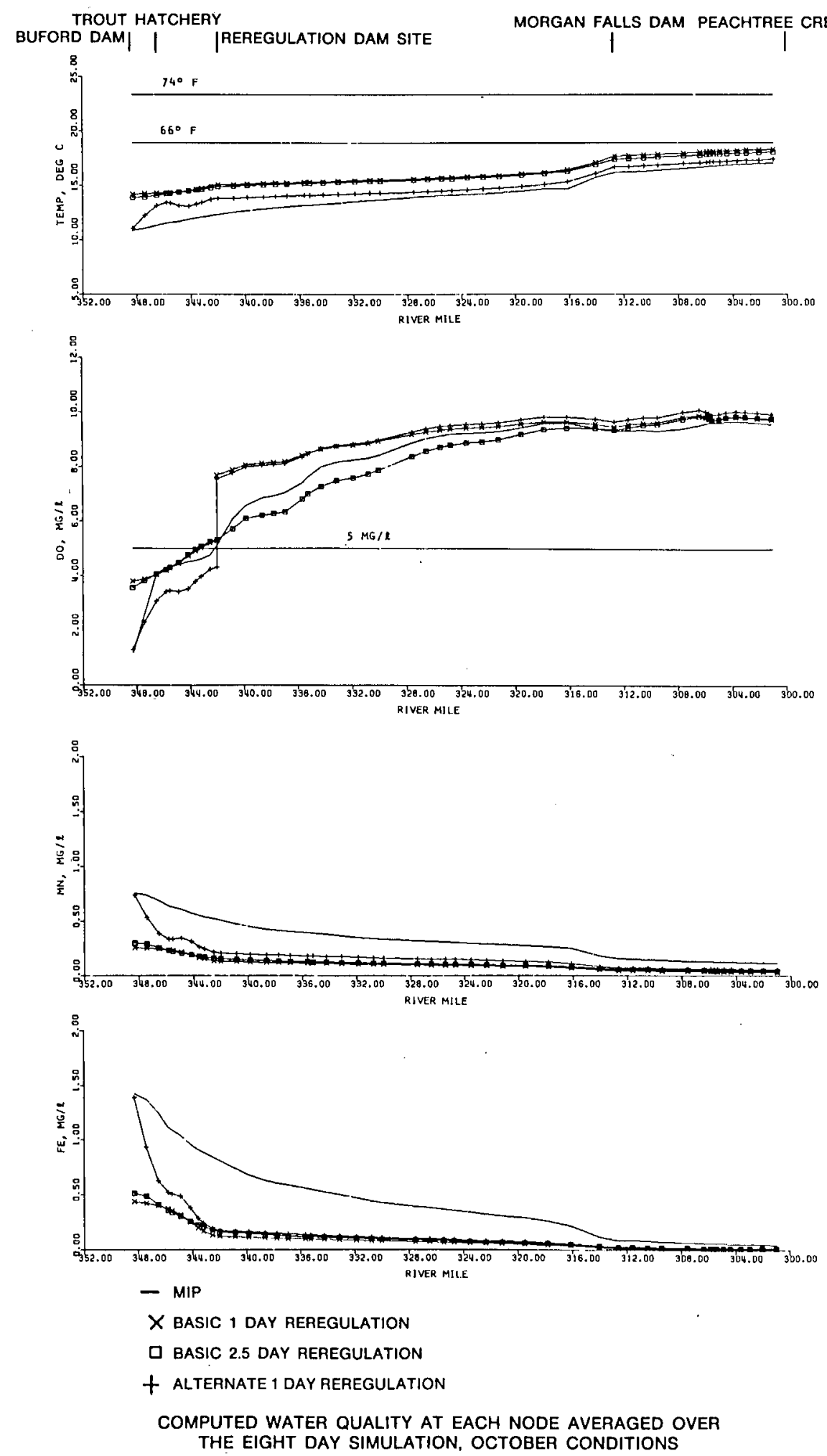

Figure 26. Computed water quality comparing effects of Modified Interim Plan with three rereg operation alternatives, averaged over 8-day simulation, October conditions 

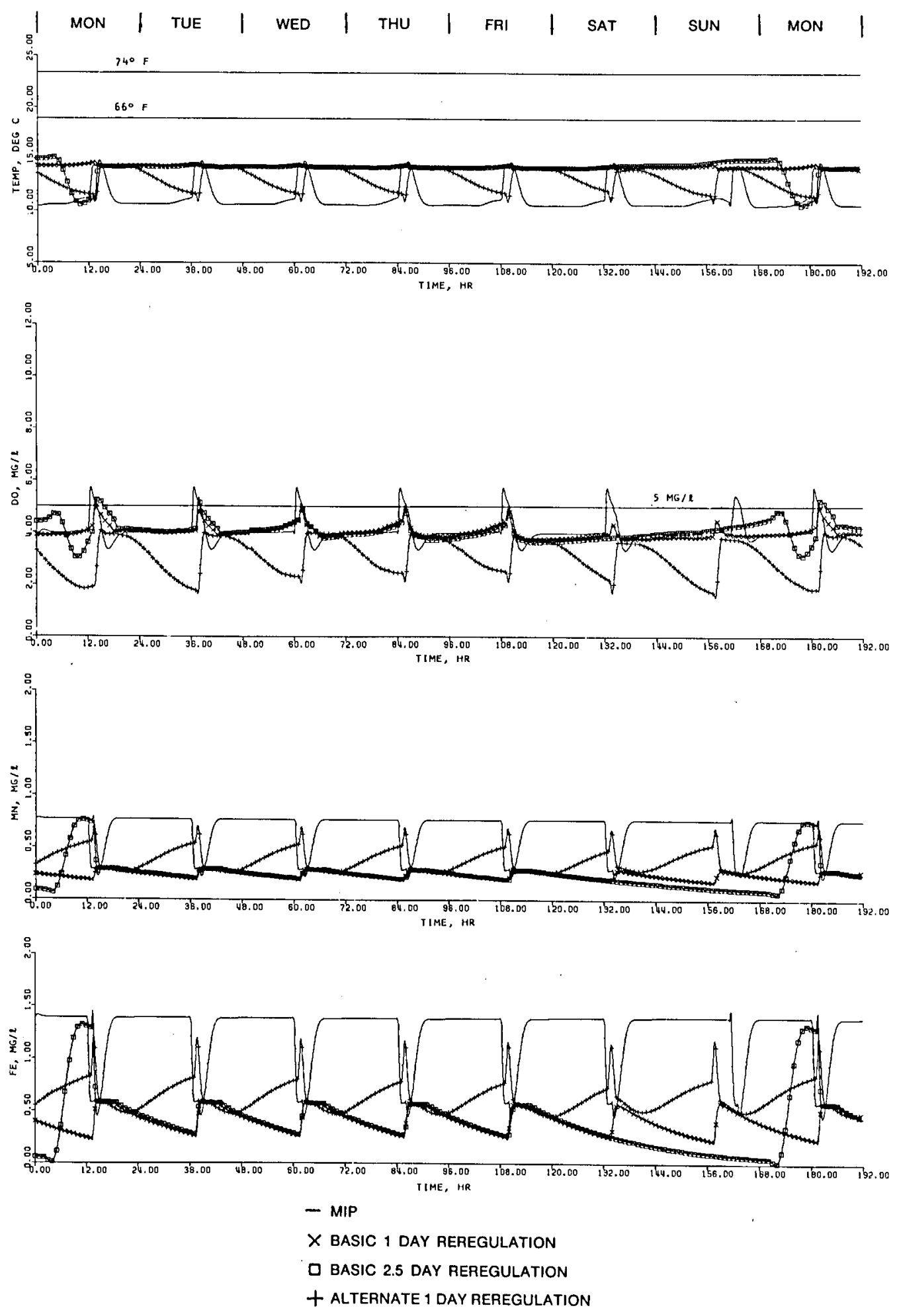

COMPUTED WATER QUALITY AT TROUT HATCHERY, OCTOBER CONDITIONS

Figure 27. Computed water quality at trout hatchery comparing effects of Modified Interim Plan with three rereg operation alternatives, October conditions 

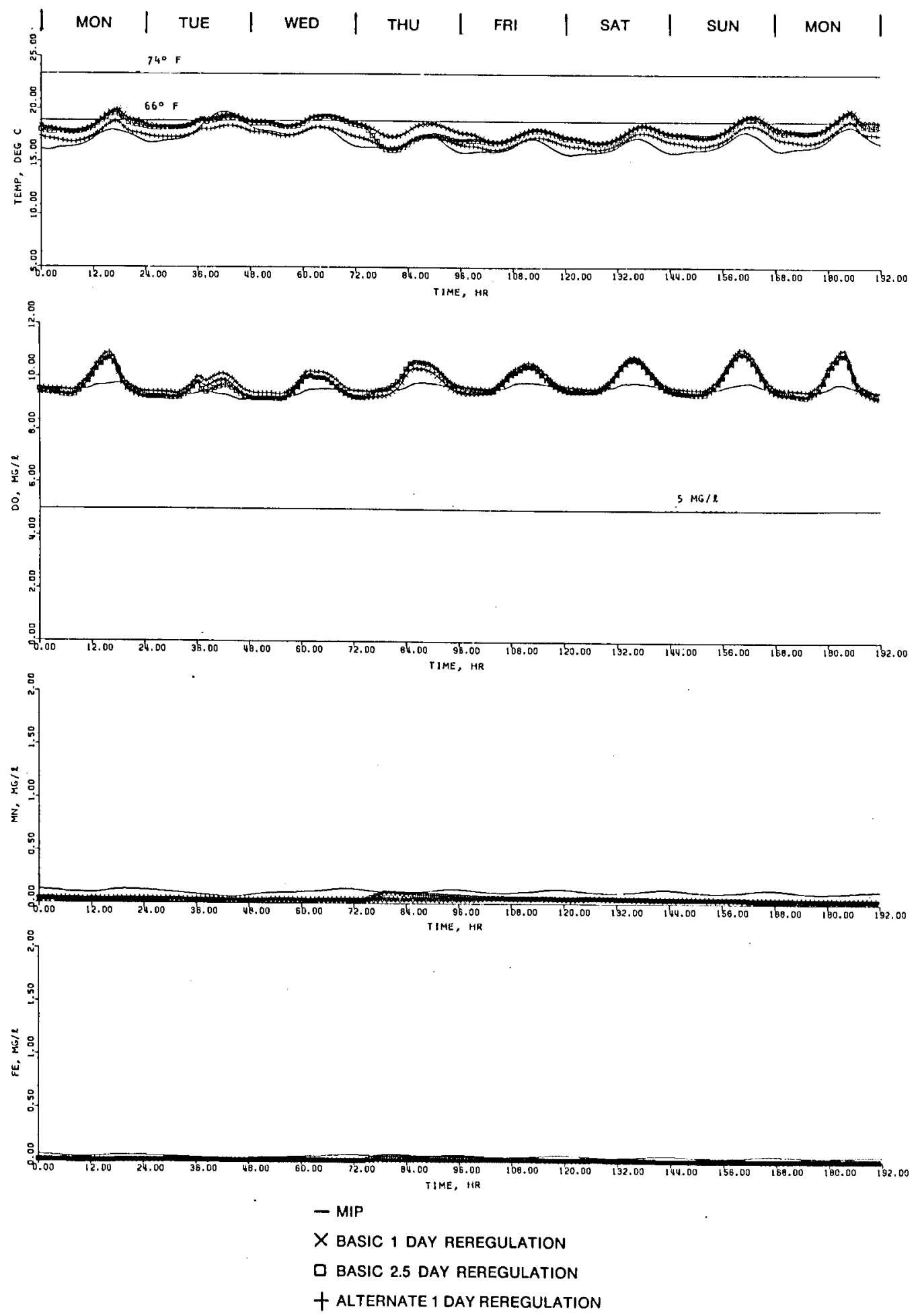

COMPUTED WATER QUALITY AT PEACHTREE CREEK, OCTOBER CONDITIONS

Figure 28. Computed water quality at Peachtree Creek comparing effects of Modified Interim Plan with three rereg operation alternatives, October conditions 

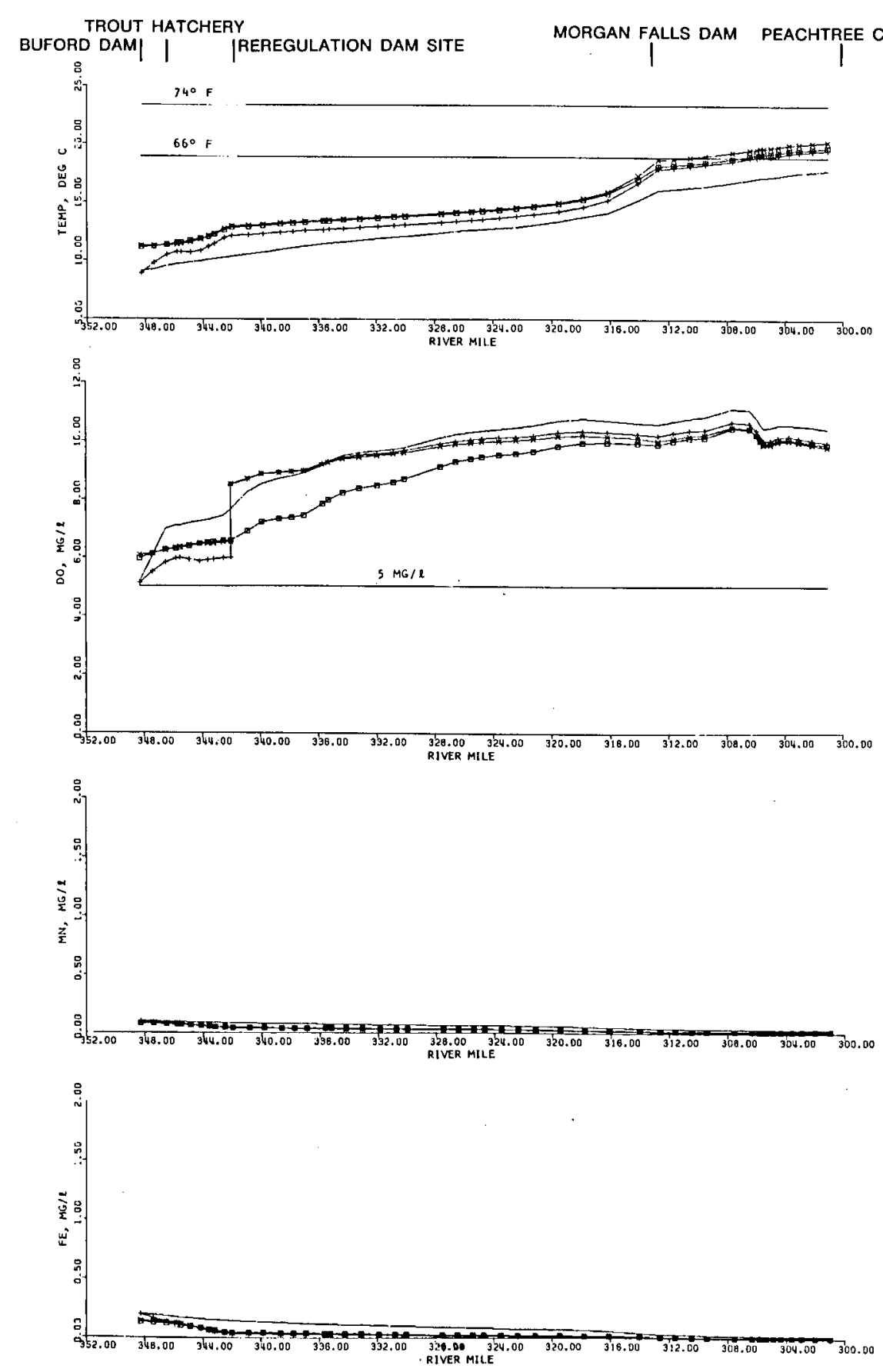

- PLAN B

$\times$ Basic 1 day Reregulation

口 BASIC 2.5 DAY REREGULATION

+ alternate 1 DAY REREgulation

COMPUTED WATER QUALITY AT EACH NODE AVERAGED OVER THE EIGHT DAY SIMULATION, JULY CONDITIONS

Figure 29. Computed water quality comparing effects of Plan B with three rereg operation alternatives, averaged over 8-day simulation, July conditions 

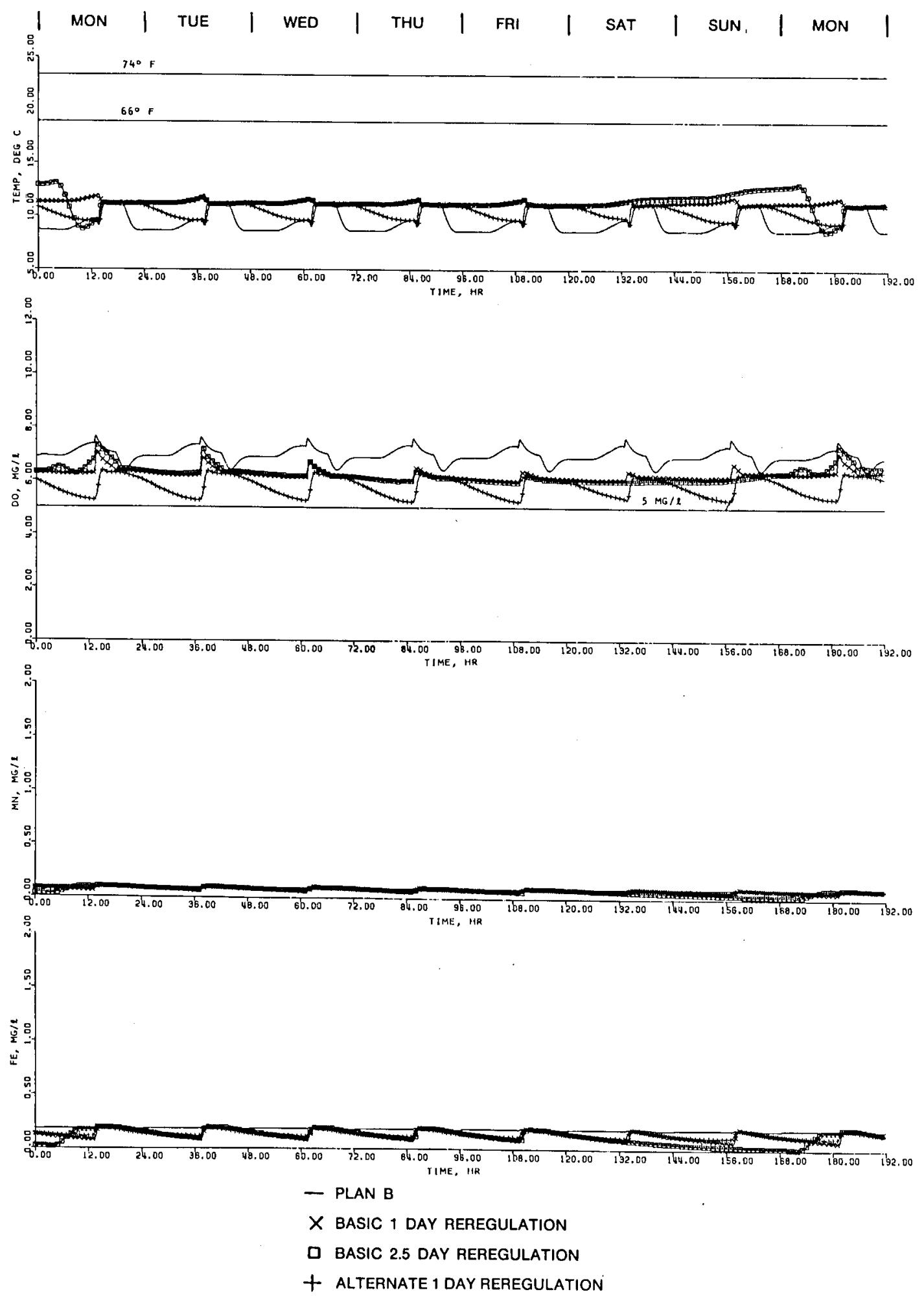

COMPUTED WATER QUALITY AT TROUT HATCHERY, JULY CONDITIONS

Figure 30. Computed water quality at trout hatchery comparing effects of Plan B with three rereg operation alternatives, July conditions 

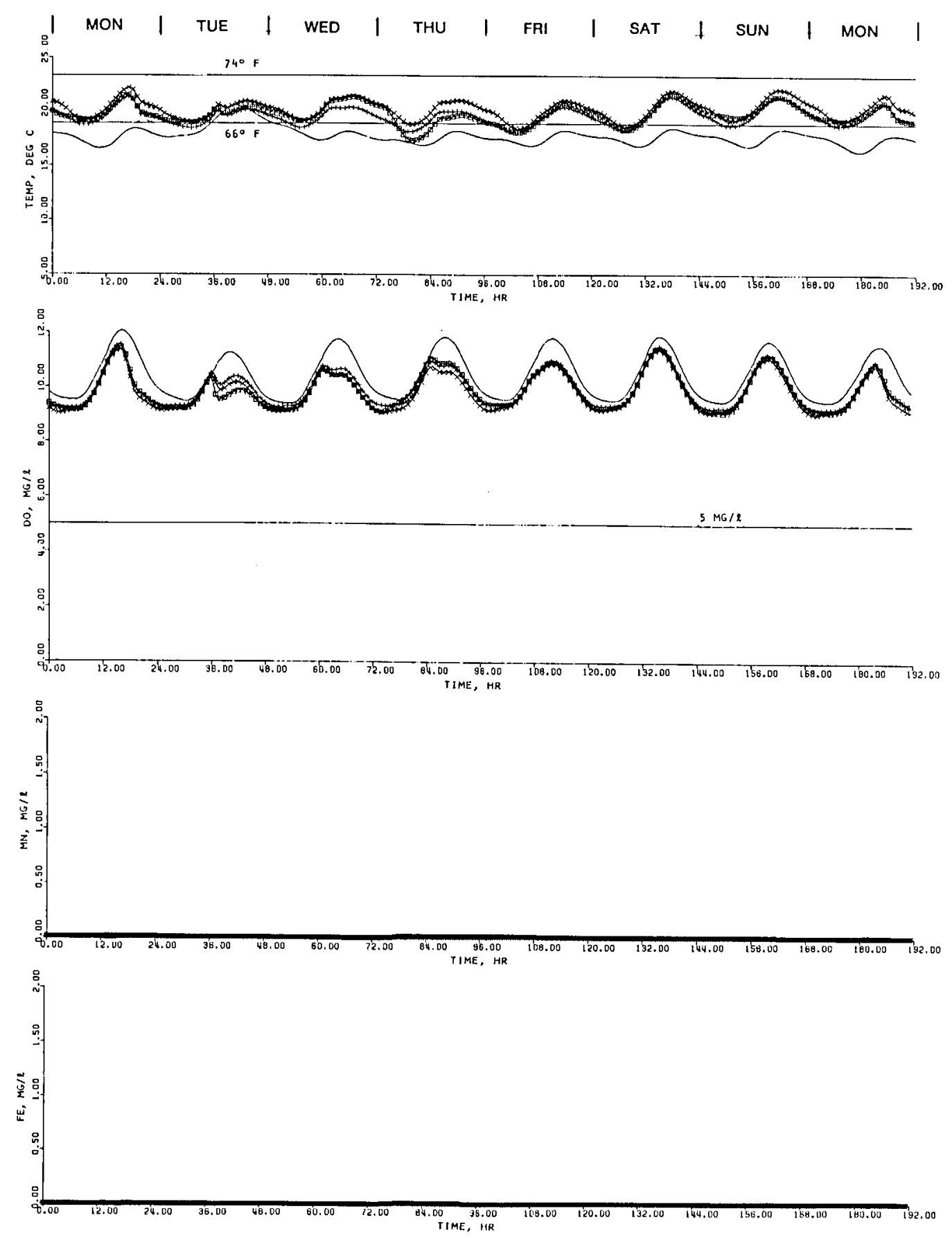

-'PLAN B

$X$ BASIC 1 DAY REREGULATION

口 BASIC 2.5 DAY REREGULATION

+ alternate 1 day REREgulation

COMPUTEO WATER QUALITY AT PEACHTREE CREEK, JULY CONDITIONS

Figure 31. Computed water quality at Peachtree Creek comparing effects of Plan B with three rereg operation alternatives, July conditions 
TROUT HATCHERY
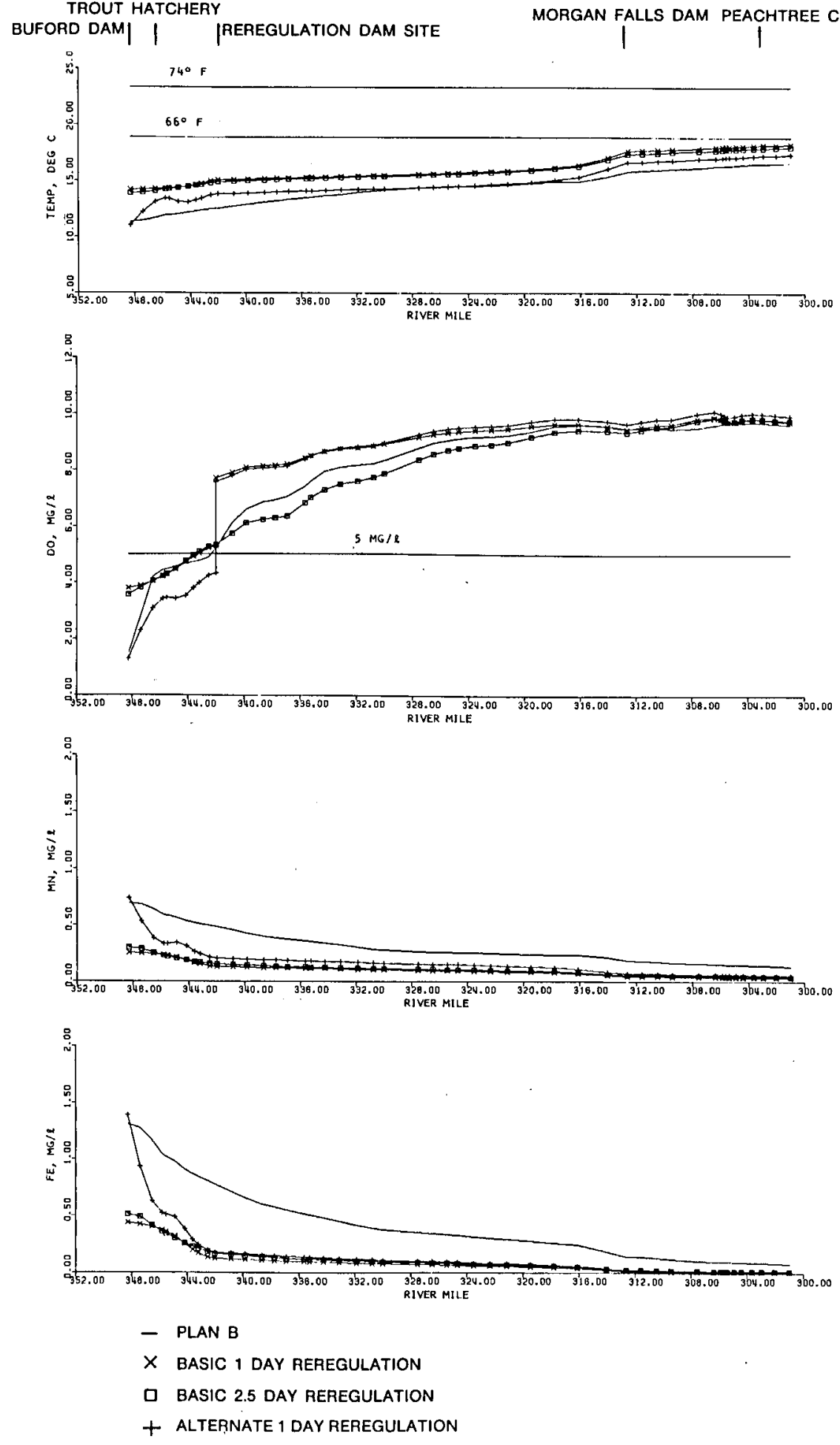

COMPUTED WATER QUALITY AT EACH NODE AVERAGED OVER

THE EIGHT DAY SIMULATION, OCTOBER CONDITIONS

Figure 32. Computed water quality comparing effects of

Plan B with three rereg operation alternatives, averaged over 8-day simulation, October conditions 

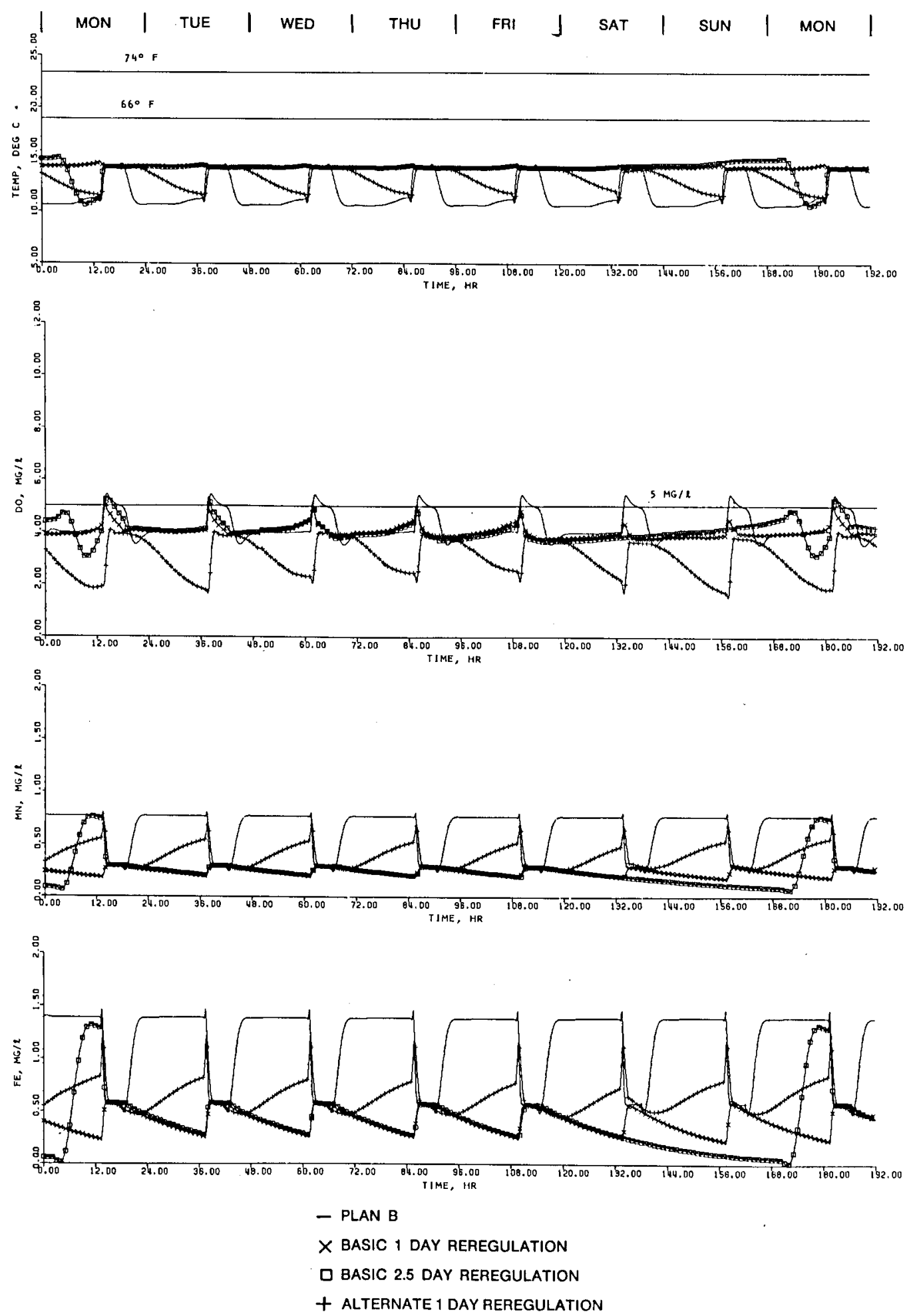

COMPUTED WATER QUALITY AT TROUT HATCHERY, OCTOBER CONDITIONS

Figure 33. Computed water quality at trout hatchery comparing effects of plan B with three rereg operation alternatives, October conditions 

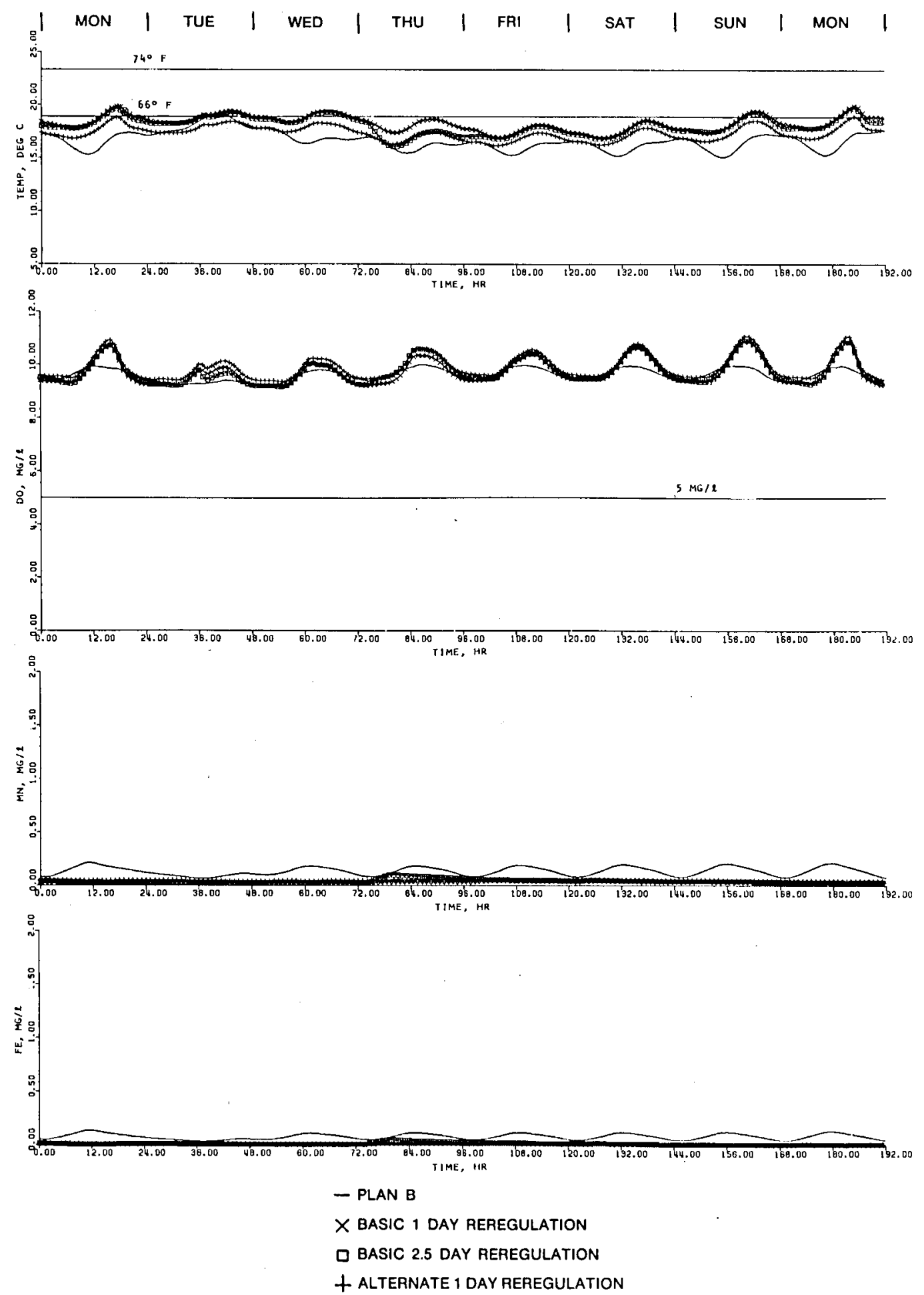

COMPUTED WATER QUALITY AT PEACHTREE CREEK, OCTOBER CONDITIONS

Figure 34. Computed water quality at Peachtree Creek comparing effects of $\mathrm{Plan} B$ with three rereg operation alternatives, October conditions 
